\title{
Strongly Peraluminous Granites across the Archean-Proterozoic Transition
}

\author{
Claire E. Bucholz ${ }^{1 *}$ and Christopher J. Spencer ${ }^{2}$
}

1Division of Geological and Planetary Sciences, California Institute of Technology, 1200 E California Blvd, Pasadena, CA 91125, USA; ${ }^{2}$ Earth Dynamics Research Group, The Institute of Geoscience Research (TIGeR), School of Earth and Planetary Sciences, Curtin University, Perth, WA 6845, Australia

*Corresponding author. Telephone: 626-395-1315. E-mail: cbucholz@caltech.edu

Received February 11, 2019; Accepted June 3, 2019

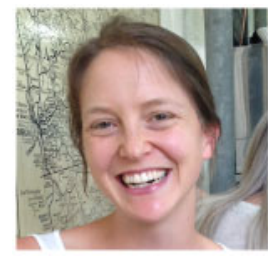

\begin{abstract}
Claire Bucholz is an assistant professor in the Division of Geological and Planetary Sciences at the California Institute of Technology. She earned her BS from Yale University before pursuing a PhD in Geochemistry from the Massachusetts Institute of Technology-Woods Hole Oceano graphic Institution Joint Program in formation and evolution of the continental crust with a particular emphasis on subduction-zone mag matism and strongly peraluminous granites. She approaches her work through field-based studies, numerous analytical techniques, and geochemical modeling.
\end{abstract}

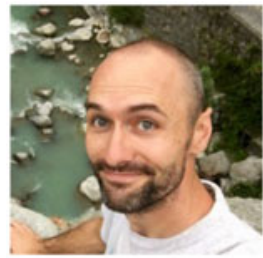

Christopher Spencer is a senior research fellow in The Institute of Geoscience Research (TIGeR) and School of Earth and Planetary Sciences at Curtin University. He earned his BS and MS from Brigham Young University and a PhD from the University of St Andrews in 2014. Using field work, mass spectrometry, and isotope geochemistry, his research foci include isotopic characteristics of plate tectonics and the secular change of orogenesis and crustal growth through time.

\begin{abstract}
Strongly peraluminous granites (SPGs) form through the partial melting of metasedimentary rocks and therefore represent archives of the influence of assimilation of sedimentary rocks on the petrology and chemistry of igneous rocks. With the aim of understanding how variations in sedimentary rock characteristics across the Archean-Proterozoic transition might have influenced the igneous rock record, we compiled and compared whole-rock chemistry, mineral chemistry, and isotope data from Archean and Paleo- to Mesoproterozoic SPGs. This time period was chosen as the Archean-Proterozoic transition broadly coincides with the stabilization of continents, the rise of subaerial weathering, and the Great Oxidation Event (GOE), all of which left an imprint on the sedimentary rock record. Our compilation of SPGs is founded on a detailed literature review of the regional geology, geochronology, and inferred origins of the SPGs, which suggest derivation from metasedimentary source material. Although Archean and Proterozoic SPGs are similar in terms of mineralogy or major-element composition owing to their compositions as near-minimum melts in the peraluminous haplogranite system, we discuss several features of their mineral and wholerock chemistry. First, we review a previous analysis of Archean and Proterozoic SPGs biotite and whole-rock compositions indicating that Archean SPGs, on average, are more reduced than Proterozoic SPGs. This observation suggests that Proterozoic SPGs were derived from metasedimentary sources that on average had more oxidized bulk redox states relative to their Archean counterparts, which could reflect an increase in atmospheric $\mathrm{O}_{2}$ levels and more oxidized sedimentary source rocks after the GOE. Second, based on an analysis of $\mathrm{Al}_{2} \mathrm{O}_{3} / \mathrm{TiO}_{2}$ whole-rock ratios
\end{abstract}


and zircon saturation temperatures, we conclude that Archean and Proterozoic SPGs formed through partial melting of metasedimentary rocks over a similar range of melting temperatures, with both 'high-' and 'low-'temperature SPGs being observed across all ages. This observation suggests that the thermo-tectonic processes resulting in the heating and melting of metasedimentary rocks (e.g. crustal thickening or underplating of mafic magmas) occurred during generation of both the Archean and Proterozoic SPGs. Third, bulk-rock $\mathrm{CaO} / \mathrm{Na}_{2} \mathrm{O}, \mathrm{Rb} / \mathrm{Sr}$, and $\mathrm{Rb} / \mathrm{Ba}$ ratios indicate that Archean and Proterozoic SPGs were derived from partial melting of both clay-rich (i.e. pelites) and clay-poor (i.e. greywackes) source regions that are locality specific, but not defined by age. This observation, although based on a relatively limited dataset, indicates that the source regions of Archean and Proterozoic SPGs were similar in terms of sediment maturity (i.e. clay component). Last, existing oxygen isotope data for quartz, zircon, and whole-rocks from Proterozoic SPGs show higher values than those of Archean SPGs, suggesting that bulk sedimentary ${ }^{18} \mathrm{O} /{ }^{16} \mathrm{O}$ ratios increased across the Archean-Proterozoic boundary. The existing geochemical datasets for Archean and Proterozoic SPGs, however, are limited in size and further work on these rocks is required. Future work must include detailed field studies, petrology, geochronology, and constraints on sedimentary source ages to fully interpret the chemistry of this uniquely useful suite of granites.

Key Words: Archean-Proterozoic transition; Great Oxidation Event; peraluminous granites; partial melting; metasedimentary rock; assimilation

\section{INTRODUCTION}

The igneous rock record across the ArcheanProterozoic transition is characterized by dramatic changes in lithology and chemistry (Condie, 1989; Condie \& O'Neill, 2010; Keller \& Schoene, 2012; Keller \& Schoene, 2018). The continental crust in the early Archean $(>2.8 \mathrm{Ga})$ was dominated by Na-rich tonalitetrondjhemite-granodiorite (TTG) suites (as well as less abundant ultramafic to mafic greenstone terranes), but underwent a transition to being characterized by a more K-rich granite-granodiorite series in the Neoarchean (2.5-2.8 Ga) and Proterozoic (Barker, 1979; Hill et al., 1992; Smithies \& Champion, 2000; Champion \& Smithies, 2001; Moyen 2003; Martin et al., 2009; Condie \& O'Neill, 2010; Laurent et al., 2014; Halla et al., 2017; Joshi et al., 2017). Simultaneously, komatiites decreased in abundance in the volcanic rock record, being replaced by lower-MgO basalts typical of those erupted at the present day (Grove \& Parman, 2004; Arndt et al., 2009; Condie \& O'Neill, 2010). In terms of chemistry, trace element ratios, which are sensitive to degree of mantle melting and depth of source region or differentiation, changed dramatically in basalts across this time period, suggesting lower degrees of mantle melting and shallower depths of magma generation on average in the Proterozoic (Condie, 1989; Herzberg et al., 2010; Keller \& Schoene, 2012). Additionally, maximum values of oxygen isotope ratios (as expressed as $\left.\delta^{18} \mathrm{O}=\left[\left({ }^{18} \mathrm{O} /{ }^{16} \mathrm{O}\right)_{\text {sample }} /\left({ }^{18} \mathrm{O} /{ }^{16} \mathrm{O}\right)_{\text {vsmow }}-1\right] \times 1000\right]$, where VSMOW is the Vienna Standard Mean Ocean Water) in igneous and detrital zircon remained relatively low and uniform in the Archean $\left(\delta^{18} \mathrm{O}=\sim 7.5 \%\right)$, but dramatically increased in the Proterozoic $(>10 \%$ by
2.0 Ga; Valley et al., 2005; Dhuime et al., 2012; Spencer et al., 2014, 2019; Payne et al., 2015).

Understanding how these lithological and geochemical changes in igneous rocks record global transformations across the Archean-Proterozoic transition has been the focus of extensive and long-standing research. This task is complicated, however, as the ArcheanProterozoic transition was one of the most dynamic times in Earth's history, with fundamental changes occurring across geophysical, tectonic, and atmospheric realms. Although still debated, a large number of researchers agree that something akin to modern-style plate tectonics developed between $\sim 3.0$ and $2.6 \mathrm{Ga}$, resulting in collisional orogens, an increase in continental crust volume, and the stabilization of cratonic cores by the end of the Archean (McCulloch \& Bennett, 1994; Taylor \& McLennan, 1995; Condie, 1998; Condie \& O'Neill, 2010; Campbell \& Davies, 2017). In addition, the continental crust changed from being dominantly below sea level to subaerial, as evidenced by the ubiquitous occurrence of pillow basalts in Archean greenstone belts in contrast to thick sequences of clastic sediments in the early Proterozoic (Windley, 1977; Thurston, 1990; Condie, 1994; Arndt, 1999; Kump \& Barley, 2007; Flament et al., 2008; Campbell \& Davies, 2017). Concurrently the late Archean mantle began to cool significantly (Korenaga, 2008; Condie \& O'Neill, 2010; Herzberg et al., 2010) and the earliest Paleoprotoerozoic was heralded with a decrease in the volume of the preserved continental crust, a time referred to as the Rhyacian tectono-magmatic lull (Condie et al., 2009; Spencer et al., 2017). Superimposed on and potentially related to these massive changes in continental growth, tectonics, and mantle 
(a)

\section{SEDIMENT DEPOSITION \& DIAGENESIS}

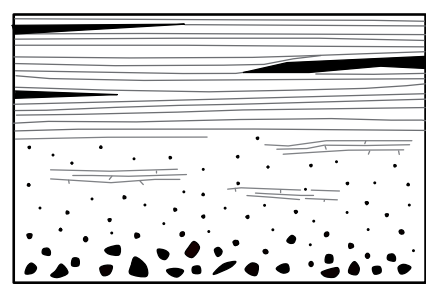

(b)

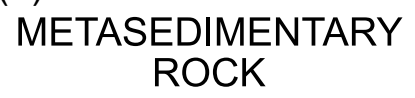

(c) STRONGLY PERALUMINOUS GRANITE

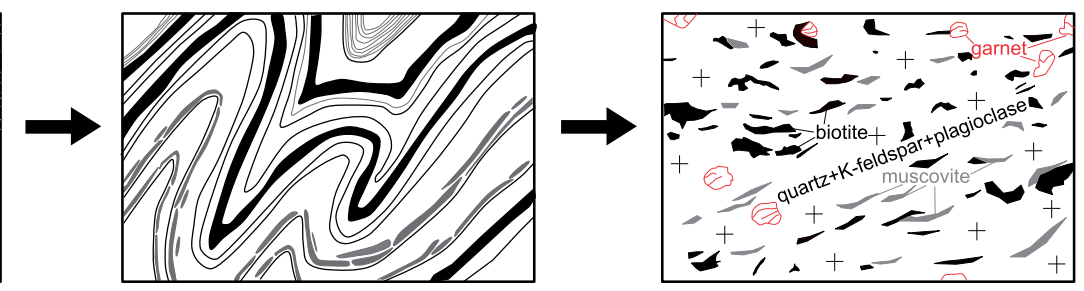

\section{Metamorphism \\ $P$ and $T$ increase \\ ( \pm deformation)}

\section{Partial Melting, Melt Extraction, and Crystallization}

Fig. 1. Branch of the rock cycle showing how strongly peraluminous granites (SPGs) are formed. (a) Sediments are deposited and transformed into sedimentary rocks through diagenesis. (b) Metamorphism of sediments and formation of metasedimentary rocks is caused by an increase in pressure and temperature during burial or heating by an external magma source. This is sometimes, but not always, accompanied by deformation. (c) If metamorphism progresses to sufficiently high temperatures $\left(>650^{\circ} \mathrm{C}\right.$ ), metasedimentary rocks may melt. Partial melts segregate and cool to form SPGs with minerals indicative of the peraluminous composition of the melt (e.g. garnet or muscovite).

dynamics, the Earth's atmosphere experienced an increase in oxygen concentrations by about five orders of magnitude at c. $2 \cdot 3-2 \cdot 4 \mathrm{Ga}$ [i.e. the Great Oxidation Event (GOE); Holland, 1984, 2002, 2006; Canfield et al., 2000; Kasting, 2001; Kump et al., 2001; Bekker et al., 2004; Catling \& Claire, 2005; Guo et al., 2009; Lyons et al., 2014; Gumsley et al., 2017]. The dramatic increase in atmospheric oxygen profoundly affected speciation of redox-sensitive elements at the surface of the Earth (e.g. Fe, S, Mo, U; Scott et al., 2008; Partin et al., 2013; Reinhard et al., 2013; Planavsky et al., 2014), which in turn destabilized some minerals during weathering (e.g. pyrite, uraninite, molybdenite; Rasmussen \& Buick, 1999), while stabilizing new classes of $\mathrm{Fe}^{3+}$-bearing clays, phosphorites/ates, and sulfates (Hazen et al., 2008, 2013; Sverjensky \& Lee, 2010).

All of these global transitions certainly affected the igneous rock record. Most directly, a change in platetectonic regime and mantle cooling would have shifted the location, depth of melting, and chemistry of magmatism. In addition, a change in sedimentary compositions owing to oxidation of the near-surface could be imprinted on the chemistry of igneous rocks through partial melting or assimilation of sediments. However, pinpointing the relationship between these global transformations during the Archean-Proterozoic transition and the major changes observed in the chemistry and lithologies of igneous rocks is difficult, as igneous rocks often record complicated, multi-faceted origins that are incompletely understood. For example, the chemistry of a felsic igneous rock may reflect its initial source, assimilation of crustal material, and differentiation processes, as well as late-stage alteration and metamorphism. Therefore, it can be hard to disentangle the source of petrological or chemical features when multiple potential causes are at play. Here we focus on a specific igneous rock type that can shed light on one piece of this complicated puzzle: strongly peraluminous granites (SPGs). SPGs are formed when sedimentary rocks (Fig. 1a) are metamorphosed (Fig. 1b) and heated to sufficiently high temperatures to partially melt. These melts may then be extracted from their source sediments and cooled, forming SPG plutons (Fig. 1c). Although SPGs are several steps removed from sedimentary rocks (e.g. metamorphism, partial melting, and crystallization), they have the potential to record variations in sedimentary compositions and thus the input of supracrustal material into magmas. Therefore, if the chemical influence of sedimentary incorporation into magmas varied across the Archean-Proterozoic transition, SPGs should record this signature, but not be influenced by other global transitions (e.g. secular cooling of the mantle). SPGs can provide a valuable tool in this puzzle to understand the relationship between changing surface conditions (such as the rise of atmospheric oxygen or onset of subaerial weathering) and the chemistry of igneous rocks across the Archean-Proterozoic transition.

The goal of this study is to catalogue and describe known localities of SPGs in the Archean and Paleo- to Mesoproterozoic, synthesize existing petrology, mineralogy, chemistry, and isotopic data from these localities, discuss these data in the context of what is known about changing surface conditions, and highlight potential avenues for future research. Although SPGs of this age range have been recognized and described (see following detailed locality descriptions), there has not been a synthesis of a global dataset of Archean and Proterozoic SPGs. The most extensive prior treatment of this subject that we are aware of comprises studies focused on the broader topic of Archean granites (Sylvester, 1994; Moyen, 2003). By compiling and analyzing existing geological, petrological, and chemical 
data for these important rocks, we hope to provide the groundwork for future studies.

\section{DEFINITION}

Before proceeding with a discussion of SPGs across the Archean-Proterozoic transition, it is necessary to define these granites. Peraluminous granites are those that include corundum in their CIPW norms (Shand, 1927). This translates into excess $\mathrm{Al}_{2} \mathrm{O}_{3}$ in their bulk composition that cannot be accommodated in feldspar by coordinating with $\mathrm{Ca}, \mathrm{Na}$, and $\mathrm{K}$. Here we define strongly peraluminous granites as granites with an aluminum saturation index (ASI) or molar $\mathrm{Al} /(\mathrm{Ca}-1.78 \mathrm{P}+\mathrm{Na}+\mathrm{K}$ ) $>1.1$ (note reduction of $\mathrm{Ca}$ by the amount necessary to combine with $\mathrm{P}_{2} \mathrm{O}_{5}$ to make apatite). In terms of mineralogy, the peraluminous nature is manifest by the presence of an aluminous mineral (other than biotite) such as muscovite, garnet, tourmaline, cordierite, kyanite, sillimanite, or andalusite (e.g. Fig. 1c). For all samples considered in this study, there is at least one of these aluminous phases present (generally, but not always in addition to biotite) in the rock.

Strongly peraluminous granites are often considered synonymous with 'S-type' granites, or those derived through the partial melting of metasedimentary rocks. In their original definition of 'S-type' granites, Chappell \& White (1974) used a variety of criteria to distinguish granitoids of the Lachlan fold belt (Australia) in addition to ASI. These included other geochemical indices, such as initial whole-rock ${ }^{87} \mathrm{Sr} /{ }^{86} \mathrm{Sr}>0.708$ and $\delta^{18} \mathrm{O} \geq 10 \%$, strongly suggesting derivation from weathered sedimentary material. However, since the initial studies of the Lachlan fold belt, other studies have demonstrated that many S-type granites from the Lachlan fold belt have a significant mantle contribution and thus are not pure melts of sediments (Gray, 1984; Collins, 1996; Healy et al., 2004; Kemp et al., 2006, 2007). For this reason, we do not label the granites discussed within this study as 'S-type', as most have not been rigorously scrutinized using modern geochemical techniques to confirm a purely sedimentary source (e.g. Hopkinson et al., 2017; Spencer et al., 2017). However, with careful review of the existing data we include only localities with sufficient geological and chemical information to suggest that they were derived predominantly, if not wholly, from a metasedimentary source region. The data we consider include geological setting, field relationships, mineralogy, and oxygen isotope data (when available).

\section{OCCURRENCES AND GEOLOGICAL SETTINGS}

SPGs of all ages typically form in collisional tectonic settings where quartzo-feldspathic sedimentary material is buried and heated to sufficient temperatures to partially melt (e.g. Sylvester, 1998; Nabelek, 2019) or syn- to post-collisional mafic magmas heat basinal (e.g. fore-arc or back-arc) sedimentary rocks (e.g. Lalonde,
1989). Archean and Proterozoic SPGs are no exception, generally being located within or associated with metasedimentary rocks of old orogenic belts. Here we briefly describe the different localities considered in this review by craton or orogenic belt, emphasizing the inferred tectonic setting, source material, and the petrogenesis of the granites. Table 1 provides further details and references on individual localities and Fig. 2 illustrates their global distribution.

We note here that we undertook an extensive review of all localities where SPGs were present, but include only those where there is clear evidence for derivation from a sedimentary source rock and significant volumes of sensu stricto granitic melt (i.e. not migmatites nor pegmatites). For example, localities that are not included in our compilation or our description here, but are worth noting, are $\sim 2.7 \mathrm{Ga}$ migmatites associated with metasedimentary rocks from the Karelia craton (Mikkola et al., 2012), the $\sim 2.9$ Ga Mata Surrao biotite \pm garnet-bearing monzogranite of the Amazonia craton (Duarte et al., 1991; Althoff et al., 2000), 2.8 Ga peraluminous pegmatites from the Pilbara craton (Blockley, 1980; Sweetapple \& Collins, 2002), numerous Neoarchean pegmatite localities associated with anataxis of clastic metasedimentary rocks in the Canadian Shield (Černý, 1990, 1991a; Breaks et al., 2003), 2.6 Ga migmatites of the Opinaca subprovince of the Superior craton (Morfin et al., 2013), 2.7 Ga migmatites of the Mkhondo Valley Metamorphic Suite (Swaziland; Taylor \& Stevens, 2010), and of the Southern Marginal Zone of the Limpopo Belt (South Africa; Nicoli et al., 2014, 2017), and $1.6-1.7 \mathrm{Ga}$ peraluminous granites of the Durlacher supersuite of the Mangaroon Orogen (Australia; Sheppard et al., 2005). In addition, we do not exclude the possibility that other localities exist that either we have missed in our literature review or have not been described or examined sufficiently to determine whether they are SPGs. Lastly, we have attempted to be thorough in our citation of existing work on the SPGs; however, there were instances where references were available only in non-English languages and we did not feel comfortable citing these references without being able to read them first-hand. These references are listed within other sources cited here and we encourage the reader to explore them.

\section{Archean localities}

\section{Superior Craton, Canada and USA}

Traditionally the Superior Craton has been subdivided into sub-provinces based on lithological characteristics (Card, 1990), with more recent efforts being focused on distinction of tectonic terranes that were juxtaposed during the Neoarchean assembly of the craton (Percival et al., 2006; Stott et al., 2010). The terranes can be broadly divided into two kinds: those dominated by (1) plutonic or orthogneissic rocks and greenstones and (2) metasedimentary rocks. The former (e.g. Uchi, Winnipeg River, Wabigoon, Wawa-Abitibi subprovinces) are considered 


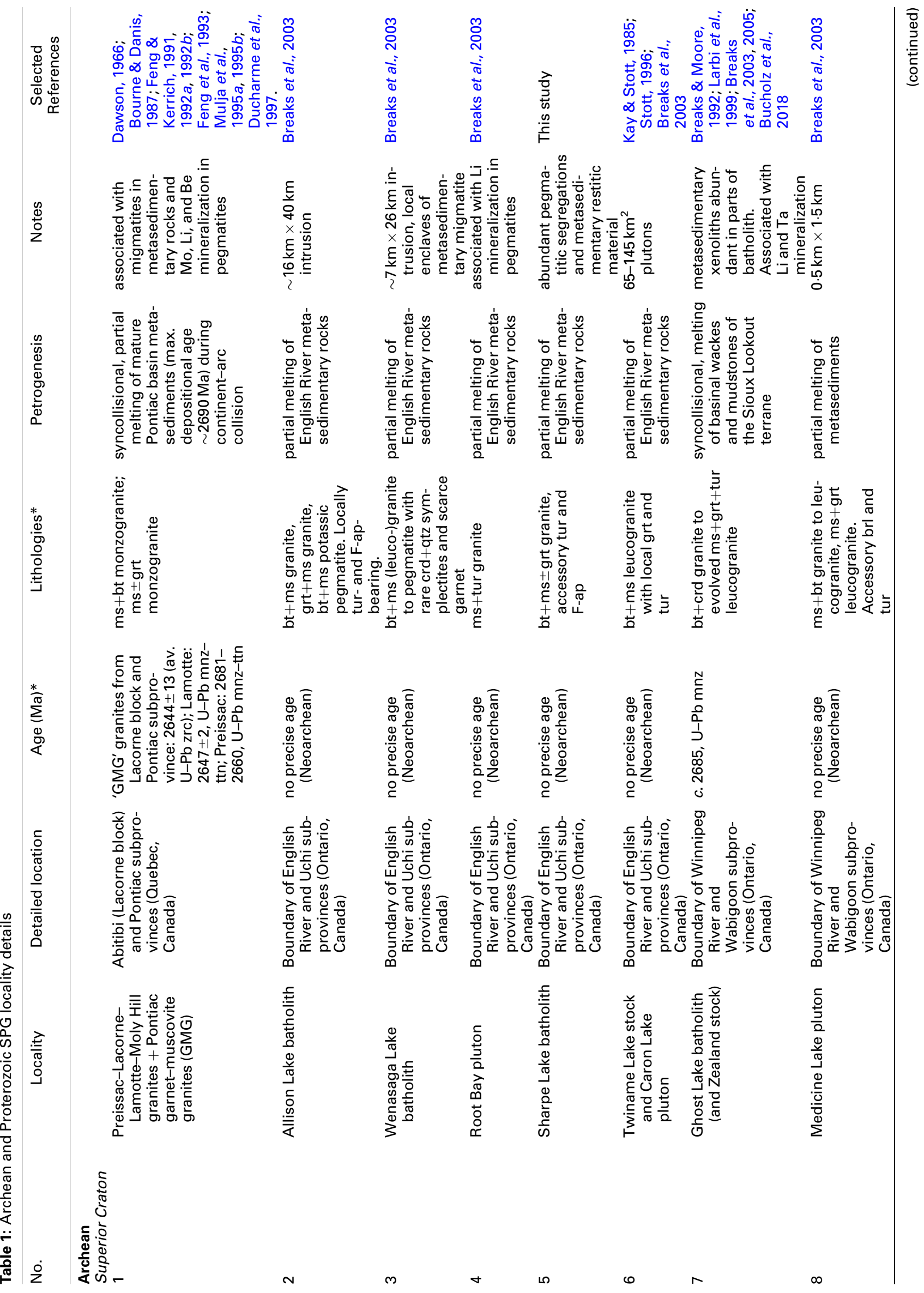




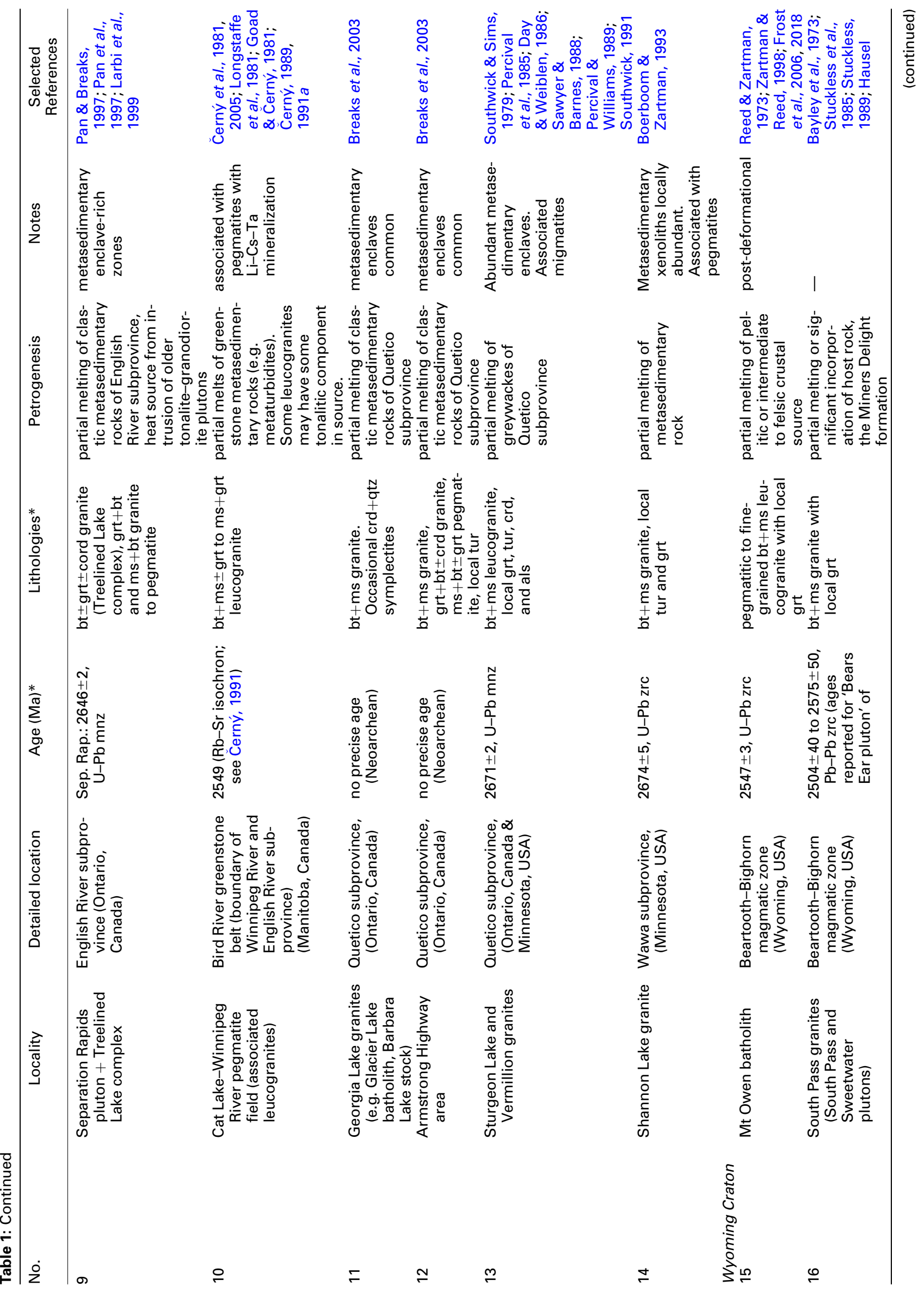




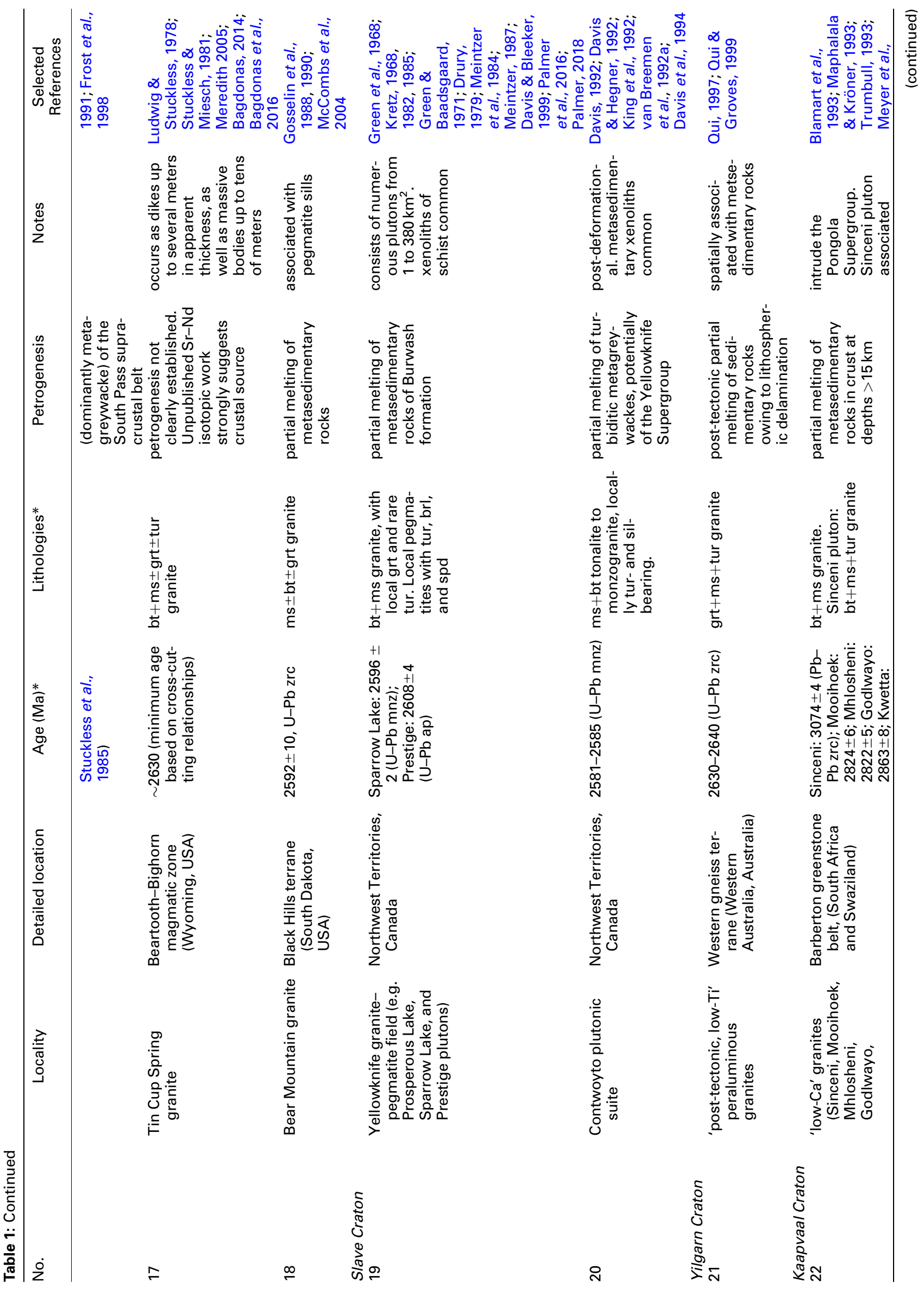




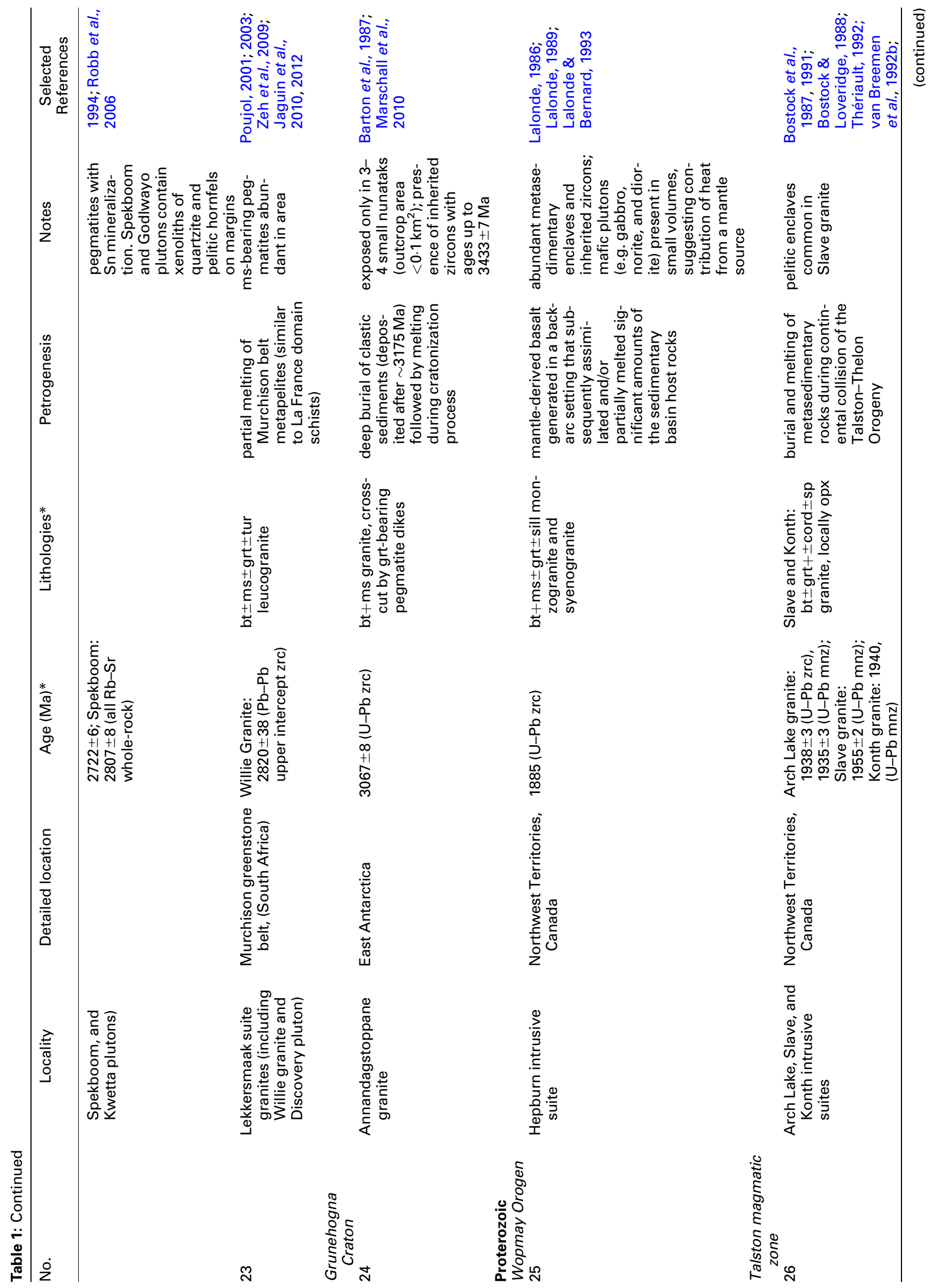




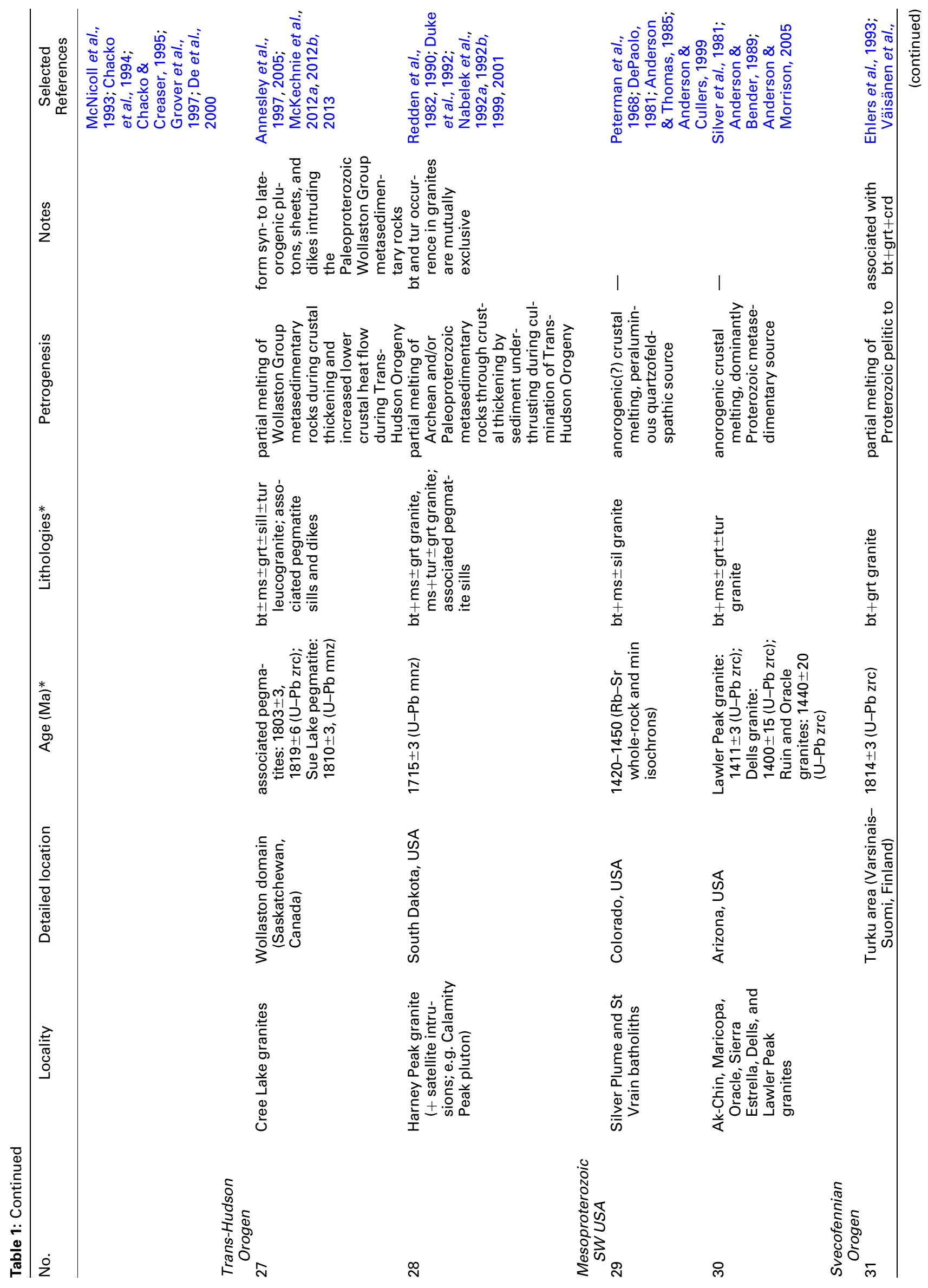




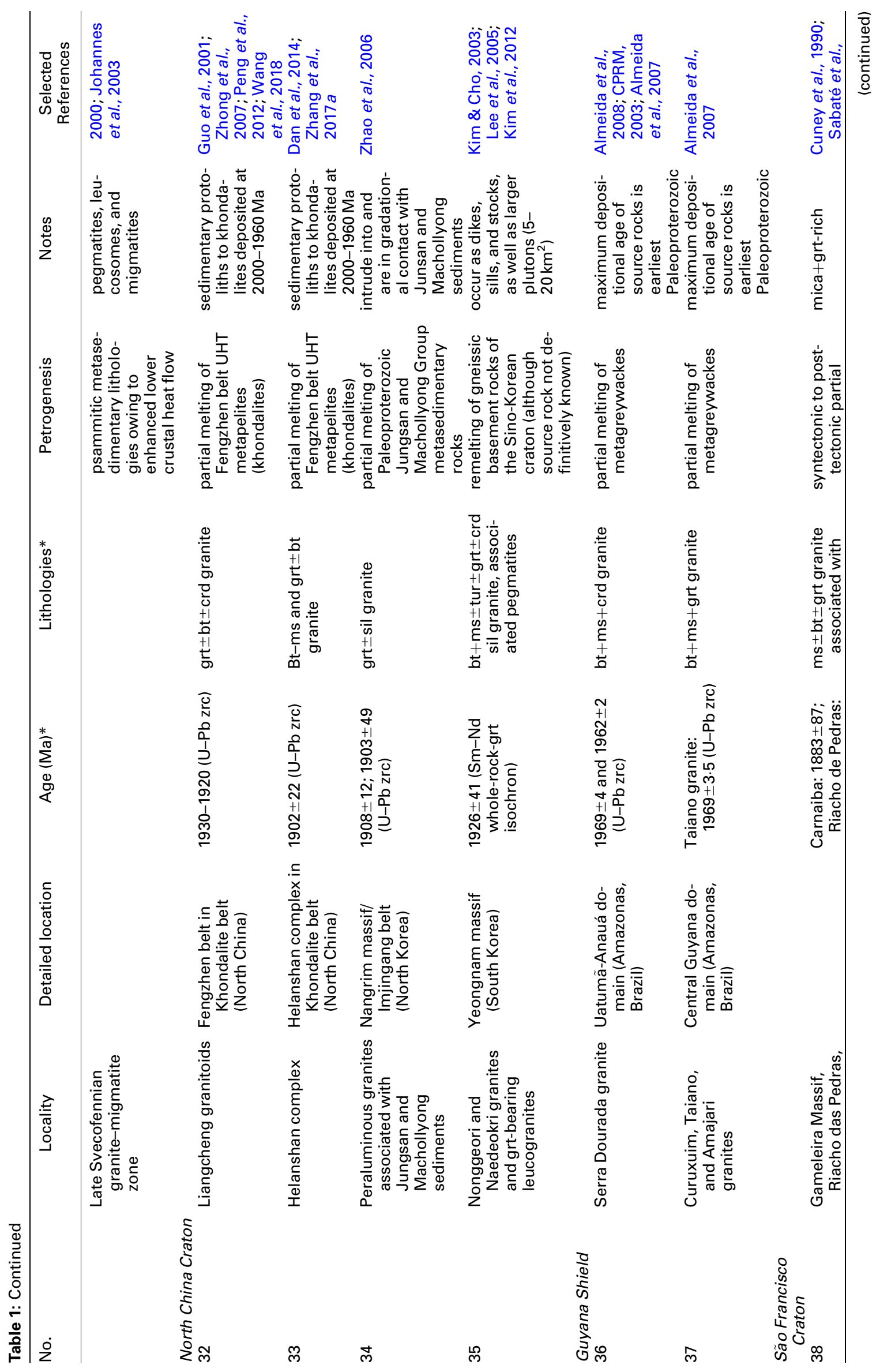




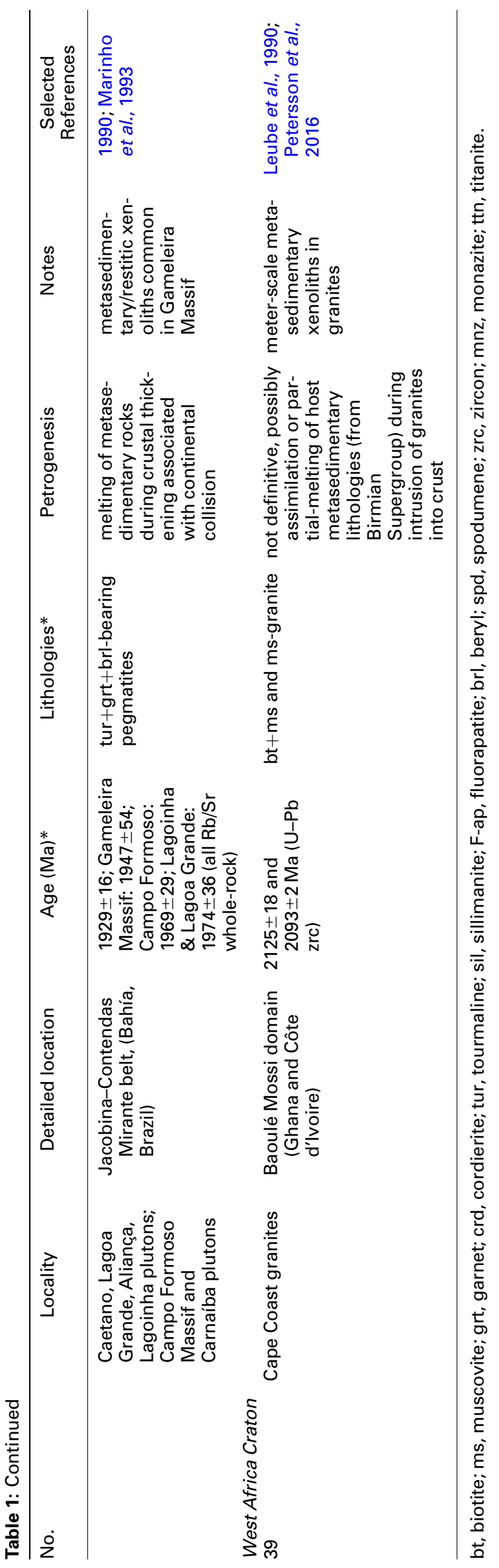




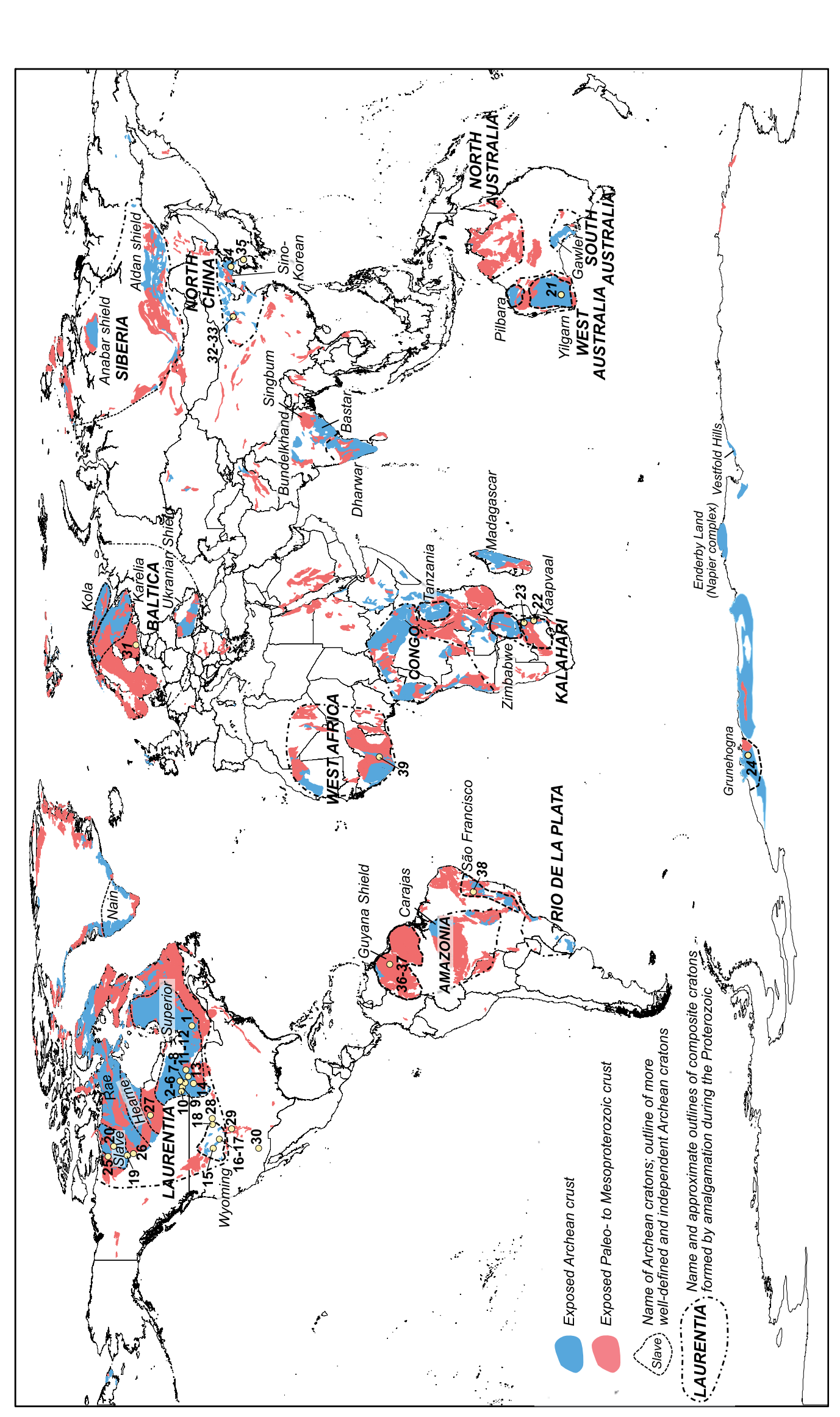

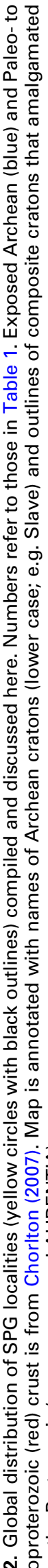



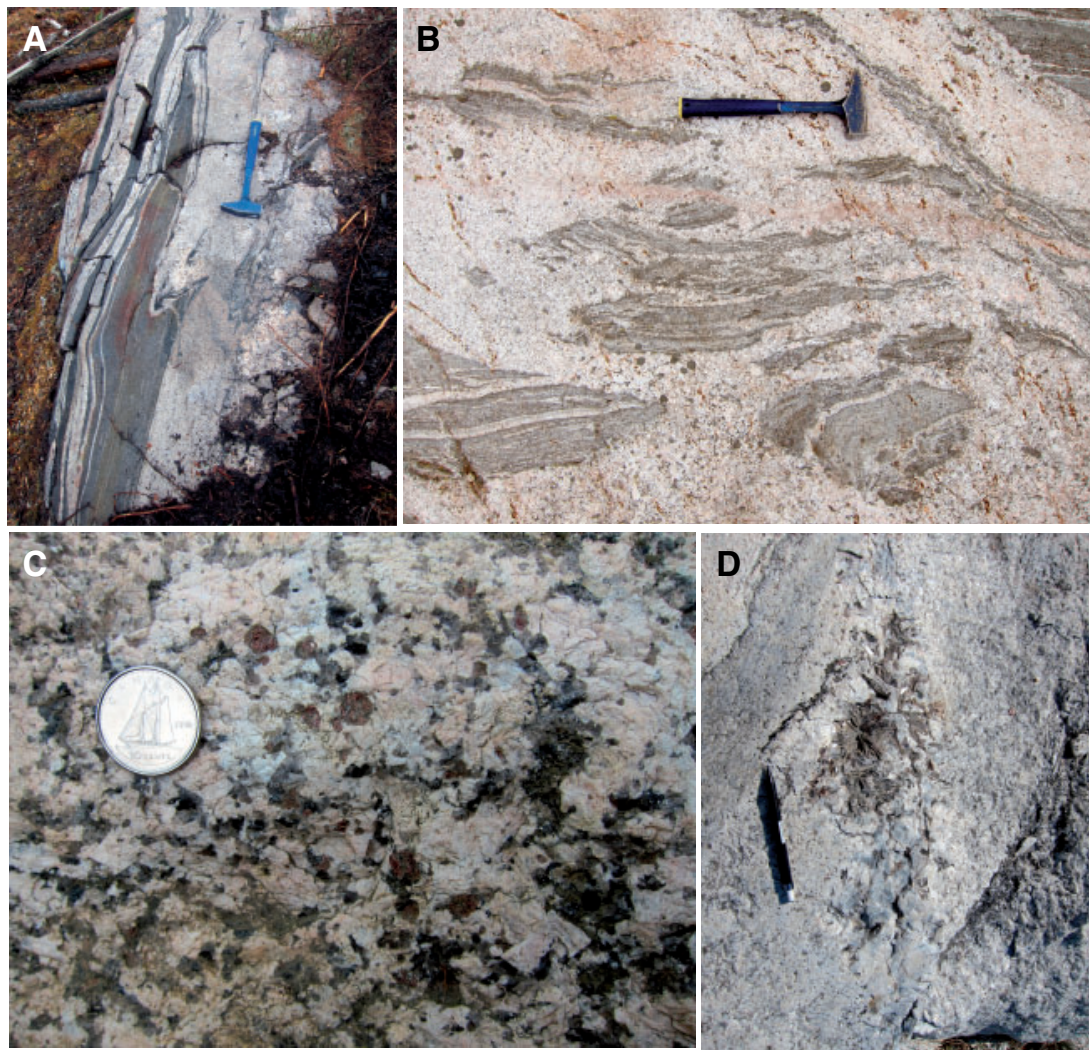

Fig. 3. Field photographs of Archean SPGs from Ontario, Canada. (a) and (b) show inclusion-rich zones of (a) the Ghost Lake batholith (location of photograph: $49^{\circ} 48^{\prime} 53 \cdot 7^{\prime \prime} \mathrm{N}, 092^{\circ} 57^{\prime} 4.7 " \mathrm{~W}$ ) and (b) migmatite zone of the English River subprovince (location of photograph: $50^{\circ} 5^{\prime} 56.9^{\prime \prime} \mathrm{N}$, $093^{\circ} 16^{\prime} 7.7^{\prime \prime W}$ ). (c) Biotite + garnet granite of Treelined Lake complex (location of photograph: $50^{\circ} 16^{\prime} 56 \cdot 1^{\prime \prime} \mathrm{N}$, $094^{\circ} 29^{\prime} 40 \cdot 2^{\prime \prime}$ W. (d) Pegmatitic pod with muscovite rosettes hosted within biotite + muscovite granite of the Ghost Lake batholith (location of photograph: $\left.49^{\circ} 48^{\prime} 53 \cdot 7^{\prime \prime} \mathrm{N}, 092^{\circ} 57^{\prime} 4 \cdot 7^{\prime \prime} \mathrm{W}\right)$. Hammer is $36 \mathrm{~cm}$ long. Mechanical pencil is $13.5 \mathrm{~cm}$ long. Diameter of coin is $18 \mathrm{~mm}$.

micro-continental fragments or arc-related plutonic-volcanic rocks, which evolved independently between 3.6 and $2.7 \mathrm{Ga}$. The latter (e.g. the English River, Quetico, and Pontiac subprovinces) are dominated by variably metamorphosed greywackes and volcanogenic turbidites, but also contain pelagic and chemical sediments such as carbonates, chert, and mudstones, and fragments of greenstone lithologies (Percival \& Williams, 1989; Breaks \& Moore, 1992; Davis, 2002). The depositional settings of these basins have been interpreted as inter-arc basins filled by synorogenic sediments from erosion of adjacent, converging terranes (Langford \& Morin, 1976; Percival \& Williams, 1989).

Five distinct accretionary events, progressive from north to south, characterize the amalgamation of the Superior Craton between 2.72 and $2.68 \mathrm{Ga}$, during which time the intervening sedimentary basins were trapped in the collisional zones (Percival \& Easton, 2007). The basin sediments underwent hightemperature metamorphism, sometimes reaching granulite-facies conditions, resulting in widespread partial melting and migmatization (e.g. Southwick, 1991; Southwick \& Sims, 1979; Pan et al., 1997; Fig. 3a and b). Many of these sedimentary provinces (and some of the plutonic provinces) contain a suite of $c .2 \cdot 6-2 \cdot 8 \mathrm{Ga} \mathrm{SPGs}$ that have been interpreted as resulting from the burial and melting of the sediments during orogenic collision (Fig. $3 c$ and d). The sub-provinces of the Superior Craton that preserve these SPGs include the Pontiac sub-province (e.g. Feng \& Kerrich, 1992a, 1992b), the English River sub-province (Breaks et al., 2003), the boundary of the Winnipeg River and Wabigoon subprovinces (Breaks \& Moore, 1992), the Quetico subprovince (e.g. Percival \& Williams, 1989; Southwick, 1991), and the Wawa subprovince (Boerboom \& Zartman, 1993) (see Table 1 for details). For a detailed discussion and review of occurrences of SPGs in Ontario, we refer the reader to the comprehensive report of Breaks et al. (2003).

\section{Wyoming Province, USA}

The Archean Wyoming Province can broadly be divided into three sub-provinces: (1) the Montana metasedimentary province; (2) the Beartooth-Bighorn magmatic zone (BBMZ); (3) the southern accreted terranes (SAT) (Chamberlain et al., 2003; Mueller \& Frost 2006). The Montana metasedimentary sub-province is located in the NW part of province and comprises Neoarchean quartzites, pelites, and carbonates together with Paleoarchean quartzo-feldspathic gneiss (Mogk et al., 
1988, 1992; Mueller et al., 1993; Mueller \& Frost, 2006). The BBMZ is primarily characterized by $\sim 2.80-2.55 \mathrm{Ga}$ tonalities and granodiorites (Mueller et al., 1996, 1998; Frost \& Fanning, 2006; Bagdonas et al., 2016). The Wyoming Province grew in the Neoarchean through accretion of southern terranes (including both recently formed magmatic terranes as well as those composed of older continental crust) between 2.68 and $2.63 \mathrm{Ga}$ to form the SAT (Chamberlain et al., 2003; Mueller \& Frost, 2006; Souders \& Frost, 2006; Bagdonas et al., 2016). A widespread, but minor subset of the Neoarchean granites in the BBMZ and SAT are SPGs. These include the Mt Owen batholith $(\sim 2.55 \mathrm{Ga})$ in the Teton Range (Frost et al., 2006, 2018), the South Pass granites $(\sim 2.55 \mathrm{Ga})$ in the southern Wind River Range (Frost et al., 1998), and the Tin Cup Spring and Long Creek Mountain granites $(\sim 2.65 \mathrm{Ga})$ of the western Granite Mountains (Stuckless $\&$ Miesch, 1981; Wall, 2004). The Bear Mountain granite of the Black Hills, South Dakota $(2.6 \mathrm{Ga})$ is thought to be part of an extension of the Wyoming Province basement, but definitive correlation between the identified sub-provinces in Wyoming is not certain (Gosselin et al., 1988, 1990; McCombs et al., 2004). The strongly peraluminous compositions and $\mathrm{Sr}$ and $\mathrm{Nd}$ isotope whole-rock data forthe Wyoming Province SPGs suggest that they formed through crustal melting of psammitic or pelitic metasedimentary rocks (Gosselin et al., 1990; Frost et al., 2006).

\section{Slave Craton, Canada}

The rocks of the Slave Craton can broadly be divided into three temporally and lithologically distinct groups: (1) basement gneisses (4.1-2.8 Ga); (2) the Yellowknife Supergroup (YKS, 2.8-2.6 Ga); (3) syn- to post-orogenic granitoid rocks $(<2.6 \mathrm{Ga})$. The YKS is a heterogeneous package of metasedimentary rocks and metavolcanic rocks. The upper member of the YKS includes turbidites deposited in the Burwash Basin c. 2.67-2.65 Ga, which has been interpreted as a back-arc basin whose closure marked the onset of final amalgamation and assembly of the Slave Craton (Henderson, 1972; Bleeker, 2003). This accretion was characterized by deformation beginning at c. $2.64 \mathrm{Ga}$, characterized by NE-SW structural trends, overthickening of the crust resulting in hightemperature-low-pressure metamorphism, and anatexis of metasedimentary rocks to produce SPGs at c. 2.61-2.59 Ga (Henderson, 1985; Davis \& Bleeker, 1999; Bleeker, 2003). SPGs occur throughout the province from the vicinity of Yellowknife near the Great Slave Lake (e.g. Prosperous Granite; Kretz, 1989) to the Contwoyto Lake area in the north-central part of the craton (Contwoyto Intrusive Suite; King et al., 1992; Davis et al., 1994). Metasedimentary protoliths of the YKS, probably quartzo-feldspathic metagreywackes of the Burwash Basin, have been proposed as the source rock of the SPGs (Drury, 1979; Meintzer, 1987; Davis et al., 1994).

\section{Yilgarn Craton, Australia}

The geological framework of Western Australia consists of two cratonic nuclei, the Pilbara Craton in the north and Yilgarn Craton in the south. The southwestern part of the Yilgarn Craton, known as the Western Gneiss terrane, is thought to represent the deepest exposed section of the craton and is characterized by charnockites, minor granulite-facies metavolcanic and metasedimentary rocks, and voluminous granitoids. The granitoids have been divided into several geochemical subgroups based on $\mathrm{Ca}$ and $\mathrm{Ti}$ contents (Champion \& Sheraton, 1997; Qui, 1997; Qui \& Groves, 1999). A 'low-Ti' subgroup comprises small discrete plutons of post-tectonic garnet-, muscovite-, and tourmaline-bearing SPGs that crystallized between 2.64 and 2.63 Ga (Qui, 1997; Qui \& Groves, 1999). Where exposed (e.g. at Griffin's Find gold mine and Nevoria goldmine) they are spatially associated with metasedimentary rocks. Their wholerock major and trace-element chemistry, peraluminous mineralogy, and abundance of inherited zircon support derivation from partial melting of metasedimentary rocks (Qui, 1997). Similar low-Ti granitoids are exposed in the Fraser's, Marvel Loch, Bounty and Edward's Find gold mines in the Southern Cross greenstone belts in the central part of the Yilgarn Craton (Qui, 1997). Their widespread geographical distribution suggests that there was a regional high-temperature thermal event in the lower crust, possibly as a result of lithospheric delamination at c. $2635 \mathrm{Ma}$ (Qui, 1997; Qui \& Groves, 1999).

\section{Kaapvaal Craton, South Africa}

The Kaapvaal Craton of southern Africa forms the oldest part of the African continent and ranges in age between $\sim 3.6$ and $\sim 2.7 \mathrm{Ga}$ (Poujol et al., 2003). It comprises four geographical domains (Northern, Eastern, Central, and Western) characterized by granite-greenstone belts. SPGs in the Kaapvaal Craton are found in the Eastern and Northern domains. The Eastern domain is the oldest portion of the craton and includes the $3.45-3.25 \mathrm{Ga}$ Barberton greenstone belt and the 3.1-2.9 Ga Pongola Supergroup (Hegner et al., 1984). A suite of granites intruding the Pongola metasediments are referred to as the 'post-Pongola granites' (Matthews, 1985). These plutons include marginally peraluminous granites (ASI $=1-1.1$ ) such as the Mooihock, Mhlosheni, and Spekboom plutons, as well as SPGs such as the Sinceni and Godlwayo plutons (ASI > 1.1; Meyer et al., 1994). These plutons have all been classified as either 'S-type' or 'ilmenite-series' granites (Meyer et al., 1994; Ishihara et al., 2002). The Sinceni pluton may be as old as $\sim 3.07 \mathrm{Ga}[\mathrm{Pb}-\mathrm{Pb}$ evaporation zircon age, Maphalala \& Kröner, 1993; although see Robb et al. (2006) questioning the $>3 \mathrm{Ga}$ age and Trumbull (1993) reporting a $\mathrm{Rb}-\mathrm{Sr}$ whole-rock isochron age of $2990 \pm 43 \mathrm{Ma}$, whereas the other leucogranites formed between 2.86 and $2.82 \mathrm{Ga}$ (Maphalala \& Kröner, 1993). The younger plutons are leucogranites that 
display field relationships with the Pongola Supergroup suggesting high-temperature interaction and assimilation, such as contact migmatites and xenoliths of quartzite and pelitic hornfels along their margins (Matthews, 1985). In contrast, the intrusive relationship with the Pongola Basin metasediments is unknown for the Sinceni pluton, which is a coarse-grained granite with minor amounts of biotite, muscovite, and tourmaline (Blamart et al., 1993; Trumbull, 1993). In addition to peraluminous mineralogy, the initial ${ }^{87} \mathrm{Sr} /{ }^{86} \mathrm{Sr}$ ratio of the Sinceni pluton is radiogenic at $0.7113 \pm 0.007$ (Trumbull, 1993) suggesting derivation from an older crustal source.

Other SPGs in the Kaapvaal Craton are found in the southern portion of the Murchison greenstone belt of the Northern domain (e.g. the 2.99-2.80 Ga Lekkersmaak suite, including the Willie and Discovery plutons; Poujol \& Robb, 1999; Poujol, 2001; Zeh et al., 2009), which range in size from large plutons $(20-30 \mathrm{~km}$ in diameter) to pegmatitic dikes. Typically, they are biotite- and muscovite-bearing leucogranites with sporadic occurrences of garnet and tourmaline (Jaguin et al., 2010). It has been suggested that the source rock to the granites is similar to metapelite of the La France domain schists found in the Murchison greenstone belt (Vearncombe, 1988; Jaguin et al. 2010; Block et al., 2013).

\section{Grunehogna Craton, Antarctica}

The Grunehogna Craton in East Antarctica is thought to have formed as part of or adjacent to the Kalahari Craton of southern Africa, but remained attached to Antarctica during the breakup of Gondwana in the Jurassic (e.g. Fitzsimons, 2000). The Archean basement of the craton is exposed solely as a small, glacier-bound exposure or nunatak of granite with cross-cutting garnet-bearing pegmatite dikes at Annandagstoppane (or 'Boxing Day Peaks') (Barton et al., 1987; Marschall et al., 2010). The crystallization age of the granite has been dated at $3067 \pm 8 \mathrm{Ma}$ (U-Pb zircon; Marschall et al., 2010), but the granite contains inherited grains as old as $3433 \pm 7 \mathrm{Ma}$, which constrain the maximum depositional age of the sediments from which the granites were derived. Although specific sedimentary source material cannot be identified owing to the limited exposure of the granite, whole-rock chemistry and zircon $\mathrm{Hf}$ and oxygen isotopes suggest a supracrustal sedimentary source (Barton et al., 1987; Marschall et al., 2010).

\section{Paleo- and Mesoproterozoic localities Wopmay orogen, Canada}

The Wopmay orogen is an Early Proterozoic (c. 2.1$1.9 \mathrm{Ga}$ ) collisional belt located on the western edge of the Slave Craton (Hoffman \& Bowring, 1984; St-Onge \& Davis, 2018). The eastern part of the Wopmay comprises the Coronation Supergroup, which preserves a west-dipping sedimentary prism with rift-fill, passive margin, and foredeep flysch-molasses sequences that accumulated within a back-arc basin (Hoffman, 1980; Hildebrand et al., 1987; Lalonde, 1989). In the western part of the Coronation Supergroup, these sedimentary units were thrust onto underlying Archean basement, translated eastward, and subsequently intruded and metamorphosed by the Hepburn intrusive suite during the Calderian orogeny at c. $1885 \mathrm{Ma}$ (Hoffman \& Bowring, 1984; King, 1986). The Hepburn intrusive suite is composed of $\sim 100$ plutons with $2750 \mathrm{~km}^{2}$ of exposure along two north-south-trending belts (Lalonde, 1989). The plutons of the Hepburn intrusive suite are variable, ranging continuously from gabbro to granite, but are dominated by peraluminous monzogranites and syenogranites. The Hepburn intrusive suite has been interpreted as the product of mantle-derived basalt generated in a back-arc setting, which subsequently assimilated and/or partially melted significant amounts of the sedimentary basin host rocks (Hoffman et al., 1980; Lalonde, 1989).

\section{Talston magmatic zone, Canada}

The Talston-Thelon orogen is an $\sim 2500 \mathrm{~km}$ long orogenic belt marking the suture between the $2 \cdot 0-2.4 \mathrm{Ga}$ Buffalo Head terrane to the west and the Archean Churchill province to the east (Bostock et al., 1987; Hoffman, 1988; Ross et al., 1991). In the southern part of the orogen, the Talston magmatic zone in Alberta and the Northwest Territories is composed of granitoids that intrude pre-2.0 Ga basement characterized by ortho- and paragneisses, high-grade pelitic metasedimentary rocks, and amphibolites (Bostock et al., 1991; van Breemen et al., 1992b; McNicoll et al., 1994; Chacko et al., 2000; De et al., 2000). The granitoid series are characterized by an early phase of biotite and hornblende-biotite granodioritic to granitic intrusions at c. 1.99-1.93 Ga, which was followed by the intrusion of a large volume of SPGs from 1.95 to $1.93 \mathrm{Ga}$ (see summary given by Chacko et al., 2000). The latter include the biotite \pm garnet \pm cordierite \pm spinel granitoids of the Slave and Konth suites (Bostock et al., 1987, 1991; Bostock \& Loveridge, 1988) and the biotite \pm garnet granitoids of the Arch Lake suite (McNicoll et al., 1993). The SPGs often contain enclaves of basement metapelites (Bostock et al., 1987; Thériault, 1992; Chacko \& Creaser, 1995; Grover et al., 1997). Based on $\mathrm{U}-\mathrm{Pb}$ zircon and monazite ages, Bostock \& van Breemen (1994) concluded that the protoliths of the metapelites were originally deposited in the Rutledge River basin, a rift-related basin on the western margin of the Churchill Province, between 2.17 and $2.04 \mathrm{Ga}$. Whole-rock chemistry, peraluminous mineralogy, abundance of metasedimentary enclaves, and similarities in $\mathrm{Nd}$ and oxygen isotopes between metapelites and the SPGs suggest an origin of the latter primarily through partial melting of the basement metasedimentary rocks (De et al., 2000; Thériault, 1992; Chacko et al., 1994, 2000). 


\section{Trans-Hudson orogen, Canada and USA}

The Trans-Hudson Orogeny (THO) was a major collisional event closing the Manikewan Ocean and suturing the Superior Province with the Wyoming and RaeHearne cratons at c. $2 \cdot 0-1.8 \mathrm{Ga}$, and marks the largest Paleoproterozoic orogenic belt in the world (Corrigan et al., 2009). Two well-documented occurrences of SPGs occur in the THO, including those in the Wollaston domain of Saskatchewan (Annesley et al., 2005; McKechnie et al., 2012a, 2012b) and the Harney Peak Granite and satellite intrusions in the Black Hills of South Dakota (Redden et al., 1982, 1990; Duke et al., 1992; Nabelek et al., 1992a, 1992b, 1999, 2001; Shearer et al., 1992). The Wollaston domain comprises metasedimentary rocks deposited unconformably on the margins of the Hearne craton during rifting and formation of the Manikewan Ocean in the early Proterozoic (Madore \& Annesley, 1996). Sedimentary rocks of the Wollaston domain include a succession of arkoses, conglomerates, and graphitic pelites towards the base, which are overlain by calcareous clastic units, marbles, and iron formations, and are interpreted as a rift-fill sequence deposited between 2.3 and $2.1 \mathrm{Ga}$ (Madore \& Annesley, 1996; Ansdell, 2005). During the TransHudson Orogeny, these sediments were buried to depths equivalent to $0.6-0.9 \mathrm{GPa}$ and reached peak temperatures of $720-825^{\circ} \mathrm{C}$, which, combined with basaltic underplating in the lower crust, initiated large-scale crustal melting (Annesley et al., 2005). Peraluminous leucogranites and granitic pegmatites occur ubiquitously throughout the Wollaston Group and are interpreted as the products of partial melting of the Wollaston domain metasedimentary rocks (Annesley et al., 2005; McKechnie et al., 2012a, 2012b, 2013).

The Harney Peak granite $(1715 \pm 3 \mathrm{Ma}$; Redden et al., 1990) marks the culmination of the Trans-Hudson Orogeny during collision of the Wyoming Province and the western boundary of either the Superior Craton or the Dakota block (DeWitt et al., 1986; Nabelek et al., 1999). This collision resulted in the thrusting of Proterozoic metasedimentary rocks to the west over the Wyoming Craton and low-pressure (0.3-0.4 GPa), hightemperature regional metamorphism of late Archean and early Proterozoic (deposited 2100-1880 Ma) metasedimentary rocks exposed around and within the granite (Redden et al., 1982, 1990; DeWitt et al., 1986; Helms \& Labotka, 1991; Nabelek \& Bartlett, 1998). The metasedimentary rocks are dominantly quartz + muscovite \pm biotite \pm garnet schists with metapelite and greywacke protoliths (Walker et al., 1986; Redden et al., 1990). The Harney Peak granite consists of a main pluton with numerous satellite intrusions and isolated sills. The main intrusion is zoned with respect to mineralogy and oxygen isotopes, with a core composed of 'low- $\delta^{18} \mathrm{O}$ ' muscovite + biotite granites and an outer zone with 'high $-\delta^{18} \mathrm{O}^{\prime}$ muscovite + garnet + tourmaline (Nabelek et al., 1992a). Based on whole-rock chemistry, mineral chemistry, and isotopic constraints, Nabelek et al. (1992a) suggested that the core of the pluton formed through high degrees of melting of an immature Archean metasedimentary source. The ascent of these hot melts may then have triggered lower degree of melting of Proterozoic schists higher in the crust to produce the high- $\delta^{18} \mathrm{O}$ series and satellite intrusions.

\section{Southwestern USA (Colorado and Arizona)}

The time period from 1600 to $1300 \mathrm{Ma}$ in Laurentia was characterized by extensive magmatism resulting in a transcontinental belt of granitoids across the USA and Canada (e.g. Anderson \& Bender, 1989; Anderson \& Morrison, 2005). This magmatism has been classically considered to be 'anorogenic', resulting from low degrees of partial melting of dominantly Paleoproterozoic or older crustal sources (Anderson \& Bender, 1989; Anderson \& Morrison, 2005; Rämö et al., 2003). However, it has also been suggested that the magmatism was an in-board expression of orogenesis on the margin of Laurentia (Nyman et al., 1994; Kirby et al., 1995; Nyman \& Karlstrom, 1997; Karlstrom et al., 2001). Although most of these intrusions are metaluminous, biotite + hornblende granites (Anderson \& Bender, 1989; Anderson \& Morrison, 2005), a third group, and the ones considered here, are c. 1400$1500 \mathrm{Ma}$ peraluminous, two-mica granites forming a distinct province from Colorado to central Arizona and New Mexico, such as the Silver Plume and St Vrain granites of Colorado (Anderson \& Thomas, 1985; Anderson \& Cullers, 1999) and the Ak Chin, Ruin, Sierra Estrella, and Oracle granites of Arizona (Anderson \& Bender, 1989). The SPGs have been divided into two petrographic groups: (1) Silver Plume-type granites (located in Colorado) are relatively water-poor based on the occurrence of magmatic sillimanite and late crystallization of muscovite, biotite, and fluorite (Anderson \& Thomas, 1985); (2) Oracle-type granites (located in Arizona) were emplaced under more hydrous conditions, demonstrated by the early crystallization of biotite and muscovite, and lack sillimanite and fluorite as accessory phases (Anderson \& Bender, 1989). Granites from both these groups are similar to SPGs in orogenic belts in terms of their peraluminous nature and high whole-rock $\delta^{18} \mathrm{O}$ values $(10 \cdot 2-11.6 \%$; Anderson \& Morrison, 1992).

The Silver Plume and St Vrain batholiths of Colorado intrude Paleoproterozoic paragneisses and schists of the Idaho Springs Formation (Gable \& Sims, 1969; Tweto \& Schoenfeld, 1979; Anderson \& Thomas, 1985) and range in composition from two-mica monzogranite to syenogranite, with primary sillimanite occurring in the more evolved lithologies $\left(\mathrm{SiO}_{2}>\sim 70 \mathrm{wt} \%\right)$. Although $\mathrm{Sr}$ isotope compositions of the granites have been used to suggest that the Idaho Springs Formation is not itself the source material, the granites were probably derived through crustal melting of a similar peraluminous quartzo-feldspathic source at pressures of 0.7-1.0 GPa (DePaolo, 1981; Anderson \& Thomas, 
1985). Robust crystallization ages are not available for the Silver Plume and St Vrain batholiths; however, Rb$\mathrm{Sr}$ whole-rock and mineral isochrons suggest crystallization from 1420 to $1450 \pm 30 \mathrm{Ma}$ (Peterman et al., 1968).

$\mathrm{Nd}$ isotope studies on the peraluminous Oracle-type granites of Arizona concluded that they were derived from Proterozoic crust (Farmer \& DePaolo, 1984; Nelson $\&$ DePaolo, 1985). Although specific source materials were not identified, whole-rock major and trace element and oxygen isotope compositions are consistent with melting of a peraluminous, quartzo-feldspathic sedimentary source (Anderson \& Bender, 1989; Anderson \& Morrison, 2005). Peraluminous two-mica granites from Arizona have crystallization ages varying from $1440 \pm 20 \mathrm{Ma}(\mathrm{U} / \mathrm{Pb}$ zircon age) for the Oracle and Ruin granites to $c .1380 \mathrm{Ma}$ ( $\mathrm{Rb} / \mathrm{Sr}$ whole-rock age) for the Sierra Estrella granite (see summary by Anderson \& Bender, 1989).

\section{Svecofennian orogen, Finland}

The Svecofennian orogen formed through accretion of island arc complexes and older crustal fragments to the Archean basement of the Karelian craton between 1.91 and 1.87 Ga (Gaál \& Gorbatschev, 1987; Lahtinen, 1994; Nironen, 1997). The main collision at c. $1.88 \mathrm{Ga}$ produced significant quantities of syn-orogenic predominantly metaluminous granitoids (Huhma, 1986; Front \& Nurmi, 1987; Gaál \& Gorbatschev, 1987). However, in southernmost Finland a later generation of peraluminous granitic melts intruded between 1.84 and $1.81 \mathrm{Ga}$, forming a $500 \mathrm{~km}$ long and $100 \mathrm{~km}$ wide belt of intrusions (Huhma, 1986; Vaasjoki \& Sakko, 1988; Suominen, 1991; Ehlers et al., 1993; Väisänen et al., 2000). These granites are associated with granulite metamorphism and extensive migmatization (Sederholm, 1926; Hopgood et al., 1976; Edelman \& Jaanus-Järkkälä, 1983; Korsman et al., 1984) in what is known as the late Svecofennian granite-migmatite (LSGM) zone. The country rocks include pelitic and psammitic garnet-cordierite \pm spinel gneisses with intercalations of volcanic rocks and tonalitic sheets (Väisänen \& Hölttä, 1999). The cause for high-temperature metamorphism $\left(c .800^{\circ} \mathrm{C}\right.$ and $0.5-0.7 \mathrm{GPa}$ ) in the area, which resulted in partial melting of the metasedimentary rocks, is controversial, as both transpressional (Ehlers et al., 1993) and extensional (Korja \& Heikkinen, 1995; Nironen, 1997) tectonic models have been proposed; however, mafic underplating as a heat source has been suggested to be an important process (Schreurs \& Westra 1986; Van Duin \& Nieman, 1993; Väisänen et al., 2000). Perhaps the best evidence for mafic underplating is the presence of contemporaneous mafic plutonic rocks in the LSGM zone (Väisänen et al., 2000). The SPGs commonly occur as a stromatic network or garnet-, cordierite-, and biotite-bearing leucosomes in migmatitic metapelitic rocks. However, at higher metamorphic grades the volumes of granitic melt increase and garnet- and cordierite-bearing pegmatitic dikes and sheets are common (Väisänen et al., 2000). The metasedimentary rocks hosting the migmatites and the SPGs have detrital zircon age populations similar to local basement rocks. Maximum depositional ages of pre-Svecofennian quartzites are shown to shortly precede deformation and range from 1.87 to $1.84 \mathrm{Ga}$ (Bergman et al., 2008).

\section{Kondalite belt, North China Craton, China}

The North China craton (NCC) coalesced in the Late Paleoproterozoic through amalgamation and collision of terranes along three large suture zones now preserved as the Khondalite belt, the Trans-North China orogen, and the Jiao-Liao-Ji belt (e.g. Zhao et al., 2001, 2005; Wilde et al., 2002; Zhao \& Zhai, 2013). The Khondalite belt consists of khondalites (i.e. high-grade sillimanite-garnet paragneisses), which are intruded by or display transitional contacts with SPGs. The khondalites are thought to have formed during the culmination of a continental collision between the Yinshan terrane and southern Huai'an (or Ordos) terrane at c. $1.95 \mathrm{Ga}$ (e.g. Qiao et al., 2016). The protoliths to the khondalites are metapelites, metasandstones, and minor marbles deposited between 2.0 and $1.96 \mathrm{Ga}$ and metamorphosed under both granulite-facies conditions ( $c$. $1.95 \mathrm{Ga}$ ) and ultra-high-temperature (UHT) metamorphism (1.93-1.92 Ma) (Santosh et al., 2006; Peng et al., 2010; Wang et al., 2011). The SPGs are garnet-bearing granites and occur as isolated plutons over an area of about $220 \mathrm{~km} \times 80 \mathrm{~km}$. At least three episodes of SPG magmatism occurred during partial melting of the khondalites at $\sim 1.95,1.93-1.90$, and $\sim 1.85 \mathrm{Ga}$ (Yin et al., 2009, 2011; Peng et al., 2012; Dan et al., 2014; Zhang et al., 2017a; Wang et al., 2018). As an alternative mechanism to crustal thickening and burial, underplating of mantle-derived basalts, potentially during ridge subduction, has been evoked as an origin for both the UHT metamorphism and SPG generation in the eastern portion of the Khondalite belt near Liangcheng (Peng et al., 2012; Wang et al., 2018). Input from basaltic magmas is supported by the presence of numerous syn-magmatic gabbronorite intrusions and mafic dikes, and basaltic enclaves within the SPGs (Wang et al., 2018).

Muscovite- and garnet-bearing SPGs are also found in the Helanshan region located in the western part of the Khondalite belt (Dan et al., 2014; Zhang et al., 2017a). Based on zircon $\mathrm{Hf}$ and oxygen isotope compositions, geochronology, and field relationships, Dan et al. (2014) suggested that the Helanshan SPGs formed during a slab break-off event at which time mafic magmas intruded into and partially melted the khondalite source rocks. (Zhang et al. 2017a) presented a further study of the Helanshan SPGs and, based on similar trace element patterns, zircon $\mathrm{Hf}$ model ages, and whole-rock $\mathrm{Nd}$ model ages between the khondalites and SPGs, also suggested derivation of the SPGs 
through partial melting of the khondalites following a collisional orogenic event.

\section{Nangrim Massif, Imjingang Belt, and Yeongnam \\ Massif granites, North and South Korea}

Precambrian basement rocks in the Korean peninsula comprise Archean and Proterozoic metasediments and granitoids of the Nangrim (called elsewhere 'Rangnim') Massif, Imjingang Belt, Gyeonggi Massif, Okcheon Belt and Yeongnam Massif from north to south. In the northern part of North Korea Proterozoic metasedimentary rocks belong to the Paleoproterozoic Jungsan and Machollyong Groups in the Nangrim Massif and Imjingang Belt. The Jungsam group comprises primarily pelitic schists, although amphibolites, hornblendebiotite gneisses, and calc-silicate rocks are also present (Zhang et al., 2017b). The Machollyong Group occurs along a NW-SE-trending belt that has been interpreted as a Paleoproterozoic rift zone and consists of a stratigraphically lower unit of metamorphosed arkoses and volcanic rocks, a carbonate-rich middle unit (now marbles and calc-silicate rocks), and an upper unit dominated by argillaceous metasediments (Zhang et al., 2017b). Intruding into the Jungsam and Machollyong groups are garnet \pm sillimanite granites, which are interpreted as partial melts of the metasedimentary rocks (Zhao et al., 2006). At their margins the garnet-sillimanite granites are gradational with the metasedimentary rocks, varying from migmatites with leucosomes into SPGs with metasedimentary enclaves (Zhao et al., 2006). However, in the cores of the plutons, the granites become massive and homogeneous. Weighted averages of ${ }^{207} \mathrm{~Pb} /{ }^{206} \mathrm{~Pb}$ zircon ages from two samples of the SPGs yielded crystallization ages of $1908 \pm 12$ and $1903 \pm 49 \mathrm{Ma}$ (Zhao et al., 2006). One of these two samples yielded inherited zircon ages between 2.5 and $2.1 \mathrm{Ga}$, placing a maximum constraint on depositional age.

SPGs and related pegmatites also occur in South Korea at the boundary of the Ogcheon Belt and the Yeongnam Massif. The Yeongnam Massif is primarily composed of pelitic to psammo-pelitic metasedimentary rocks and orthogneiss, as well as Mesozoic granites. Detrital zircon constraints on the metasedimentary rocks from the Yeongnam Massif constrain the depositional age to c. $2.00 \mathrm{Ga}$ (Kim et al., 2012). Both small volumes of garnet-bearing leucogranites dikes, sills, and stocks (Kim \& Cho, 2003) and the larger $\left(5-20 \mathrm{~km}^{2}\right.$ in areal extent) biotite + muscovite \pm tourmaline \pm garnet-bearing Nonggeori and Naedeokri leucocratic granites (Lee et al., 2005) intruded into the metamorphic rocks. The Nonggeori and Naedeokri granites are characterized by low magnetic susceptibilities [(0.08$0.3) \times 10^{-3} \mathrm{SI}$, suggesting that they belong to the 'ilmenite-series' (Jin et al., 2001). A Sm-Nd whole-rockgarnet isochron yielded an age of $1926 \pm 41 \mathrm{Ma}$ for the garnet-bearing leucogranites (Kim \& Cho, 2003), whereas $\mathrm{K}-\mathrm{Ar}$ muscovite ages range from $1802 \pm 18$ to
$1732 \pm 16 \mathrm{Ma}$ for the Nonggeori granite and from $1787 \pm 19$ to $1773 \pm 18 \mathrm{Ma}$ for the Naedeokri granite (see summary by Lee et al., 2005). Although the tectonic history of this region is not well constrained, Lee et al. (2005) concluded, on the basis of mineralogy, wholerock chemistry, and $\mathrm{Nd}$ isotopes, that the Nonggeori and Naedeokri granites were derived from partial melting of 'crustal rocks represented by the gneissic basement of the Sino-Korean craton'.

\section{Guyana Shield granites, Brazil}

The Roraima State located in the Guyana Shield may be divided into four major geological domains (Surumu, Parima, Central Guyana, and Uatumã-Anauá), which are characterized by an intense period of Paleoproterozoic magmatism (Reis et al., 2000; Almeida et al., 2007, 2008). Two of these domains contain SPGs: the garnet-bearing Curuxium, Taiano, and Amajari granites of the Central Guyana domain (CGD) and the muscovite \pm cordierite \pm sillimanite-bearing Serra Dourada granite of the Uatumã-Anauá domain (UAD). The crystallization ages of the Taiano and Serra Dourada granites have been constrained via zircon U$\mathrm{Pb}$ geochronology at $1969 \pm 4 \mathrm{Ma}(\mathrm{CPRM}, 2003)$ and $1962 \pm 2$ Ma respectively (Almeida et al., 2007). Based on whole-rock chemistry and mineralogy, Almeida et al. (2007) suggested that the Serra Dourada granite was probably derived from partial melting of metagraywackes during collision of older Paleoproterozoic domains of the Guyana Shield. Both the Serra Dourada and the Taiano granites contain zircon with inherited cores ranging from $2138 \mathrm{Ma}$ to $2047-2072 \mathrm{Ma}$, respectively, suggesting a maximum depositional age of their source sediment in the earliest Paleoproterozoic. Although future field studies and geochronology are required to understand the detailed origin of these granites, they were probably formed during the collision of the Paleoproterozoic Anauá magmatic arc with Transamazon $(2 \cdot 2-2.0 \mathrm{Ga})$ and Central Amazonian (>2.3 Ga) terranes (Almeida et al., 2007).

\section{Jacobina-Contendas Mirante belt, São Francisco craton, Brazil}

The Jacobina-Contendas Mirante (JCM) belt is a northsouth-trending dominantly volcano-sedimentary belt in the eastern part of the São Francisco craton. The JCM belt is situated between two Archean crustal blocks: the Jequié domain and Atlantic coast 'mobile belt' to the east and the Gavião domain to the west. The Gavião domain comprises migmatitic gneisses and amphibolites that represent the basement of the JCM supracrustal sequences. The convergence between the Jequié and Gavião domains in the Paleoproterozoic was marked by the formation of basins in which the JCM belt volcanic and sedimentary rocks were deposited (Barbosa \& Sabaté, 2004). The Serra de Jacobina series of the JCM belt is an $\sim 10 \mathrm{~km}$ wide by $>200 \mathrm{~km}$ long belt of metaquartzite, meta-conglomerates, mica-schists, banded 
iron formations, and minor intercalated meta-ultramafic rocks (Cuney et al., 1990; Marinho et al., 1993). Two lithostratigraphic units have been defined in the Contendas Mirante belt: a lower unit of basalts and andesites with interbedded clastic and chemical sediments and an upper unit of greywackes, pelites and argillites with conglomerate layers (Marinho et al., 1993). A maximum depositional age defined by detrital U-Pb zircon ages from the Contendas-Mirante upper unit is $2168 \pm 18 \mathrm{Ma}$ (Nutman \& Cordani, 1993; Nutman et al., 1994).

Numerous $(>20)$ SPGs intrude the Gavião basement rocks and the JCM belt. These include, but are not limited to, the Gameleira, Riacho das Pedras, Aliança, Caetano, Lagoa Grande, and Lagoinha plutons in Contendas Mirante belt and the Campo Formos and Carnaiba plutons in the Serra de Jacobina series (Cuney et al., 1990; Sabaté et al., 1990; Marinho et al., 1993; Leal et al., 2000). $\mathrm{Rb} / \mathrm{Sr}$ whole-rock isochrons for the granites yield ages between $1974 \pm 36$ and $1883 \pm 87 \mathrm{Ma}$ (Sabaté et al., 1990). The granites are muscovite + biotite \pm garnet-bearing and sometimes associated with late muscovite-, garnet-, and tourmaline-bearing pegmatites (Cuney et al., 1990; Sabaté et al., 1990). Biotite-rich layered enclaves thought to be representative of restitic source material are present in the plutons (Cuney et al., 1990). Based on whole-rock and mineral chemistry, $\mathrm{Sr}$ and $\mathrm{Nd}$ isotope ratios, geochronology, and field relationships, the SPGs are thought to be derived through partial melting of supracrustal material during the c. $2 \mathrm{Ga}$ collision of the Jequié and Gavião domains (Cuney et al., 1990). Based on whole-rock $\mathrm{Sr}$ isotope ratios, Sabaté et al. (1990) suggested that the Archean Gavião terrane was the most likely source rock; however, Nd isotopes are in conflict with this interpretation and instead are consistent with derivation from rocks of the Contendas Mirante metasedimentary rocks.

\section{Cape Coast suite granites, Baoulé Mossi domain, Ghana and Côte d'Ivoire}

The Baoulé Mossi domain of the West African craton is a composite terrane composed of NE-SW-trending belts of early Paleoproterozoic $(\sim 2 \cdot 35-2 \cdot 20 \mathrm{Ga}$ ) tholeiitic to calc-alkaline metavolcanic rocks and metasedimentary rocks of the Birimian and Tarkwaian groups, all of which were intruded by granites at $\sim 2.1-2.0 \mathrm{Ga}$ (Boher et al., 1992; Taylor et al., 1992; Vidal \& Alric, 1994; Hirdes et al., 1996; Gasquet et al., 2003; Baratoux et al. 2011). The metasedimentary rocks of the Birimian Supergroup consist of metamorphosed volcanoclastic rocks, turbidite-related greywackes, carbonaceous argillites, cherts, carbonates, and Mn-rich sediments, interpreted as having formed in a basin proximal to a volcanic front (Leube et al., 1990). There are four main suites of granite; the Winneba, Cape Coast, Dixcove, and Bongo. Of interest here are the Cape Coast granites, which are peraluminous muscovite + biotite-bearing granitoids that predominantly occur as batholiths hosted in the Birmain metasedimentary rocks (Leube et al., 1990). Metasedimentary xenoliths in the granites (up to $10 \mathrm{~m}$ in size) have been observed (Petersson et al., 2016). These granites represent the latest stage of magmatism in the domain and formed during the accretion of various oceanic arc terranes at $\sim 2.1-2.0 \mathrm{Ga}$ (Boher et al., 1992; Pouclet et al., 1996; Gasquet et al., 2003).

Leube et al. (1990) analyzed 25 samples from the Cape Coast granite suite for whole-rock major and trace element chemistry and found that although all samples were peraluminous, only seven were strongly peraluminous. In addition, initial ${ }^{87} \mathrm{Sr} /{ }^{86} \mathrm{Sr}$ ratios $(0.70150 \pm 42)$ and $\varepsilon_{\mathrm{Nd}}(+3.7)$ values suggested a relatively depleted (i.e. mantle-like) source for these granites. A more recent study of the $\mathrm{U}-\mathrm{Pb}$ and $\mathrm{Hf}$ isotopes in zircon of three different muscovite-bearing granodioritic, granitic, and pegmatitic samples from the Cape Coast suite yielded ${ }^{207} \mathrm{~Pb} /{ }^{206} \mathrm{~Pb}$ crystallization ages of $2125 \pm 18 \mathrm{Ma}$, $2093 \pm 20 \mathrm{Ma}$, and $2092 \pm 40 \mathrm{Ma}$ respectively and initial $\varepsilon_{\mathrm{Hf}}$ values of +2.1 to +5.5 (Petersson et al., 2016). The existing collective radiogenic isotope data suggest that there is a strong mantle-derived component in the Cape Coast granites. Leube et al. (1990) suggested that the peraluminous character of the granites may have resulted from large-scale contamination of the ascending melts by volcaniclastic sediments. However, radiogenic isotope data exist for only three samples with well-described petrology (i.e. muscovite-bearing granites) and whole-rock data for these samples do not exist. We therefore have decided to include these granites in this compilation based on the strongly peraluminous nature of some of the granites, their described primary mineralogy, and their field relationships suggesting intimate association with the Birimian sedimentary rocks. However, Leube et al. (1990) reportedd only an average whole-rock chemistry of the $25 \mathrm{sam}$ ples they analyzed, so our analysis of geochemical data from this suite in subsequent discussion is hindered.

\section{PETROGRAPHY AND MINERAL CHEMISTRY}

The corundum-normative nature of SPGs requires that in addition to quartz and two feldspars they have one or more aluminous major phase such as biotite, muscovite, garnet, cordierite, aluminosilicates (sillimanite, andalusite, or kyanite), tourmaline, topaz, spinel, or corundum (Clarke, 1981). These phases can have a magmatic origin (i.e. crystallizing directly from the granitic melt) or can be entrained restitic phases (e.g. biotite and garnet; White \& Chappell, 1977; Stevens et al., 2007). If these are primary magmatic phases, the crystallization of these phases is controlled by temperature, pressure, bulk composition, fluid composition, and oxygen fugacity. As such, careful interpretation of the mineral crystallization textures, reaction relationships, and chemistry can be used to constrain these intensive variables during crystallization. As a comprehensive discussion of petrography and mineral chemistry in SPGs 


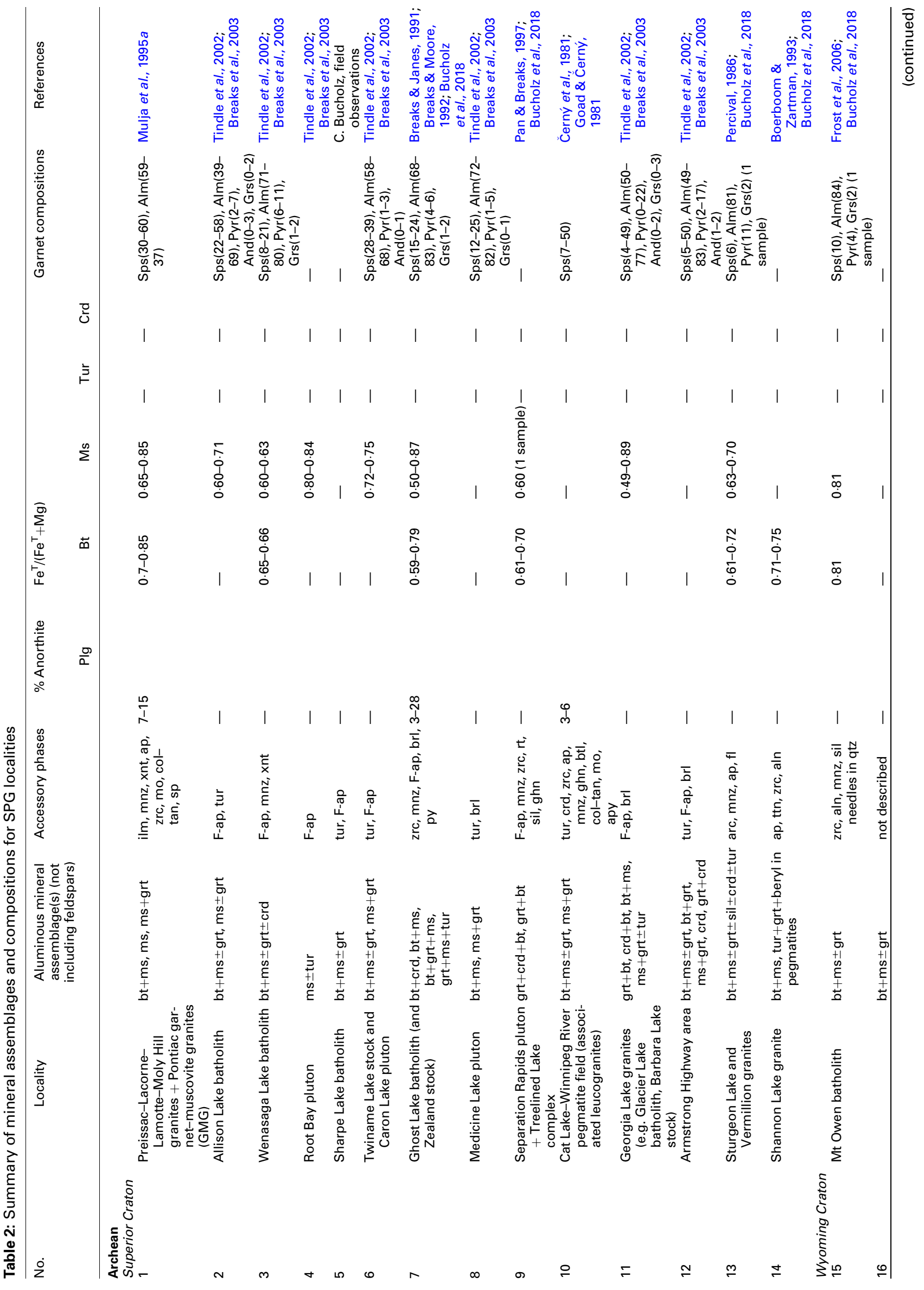




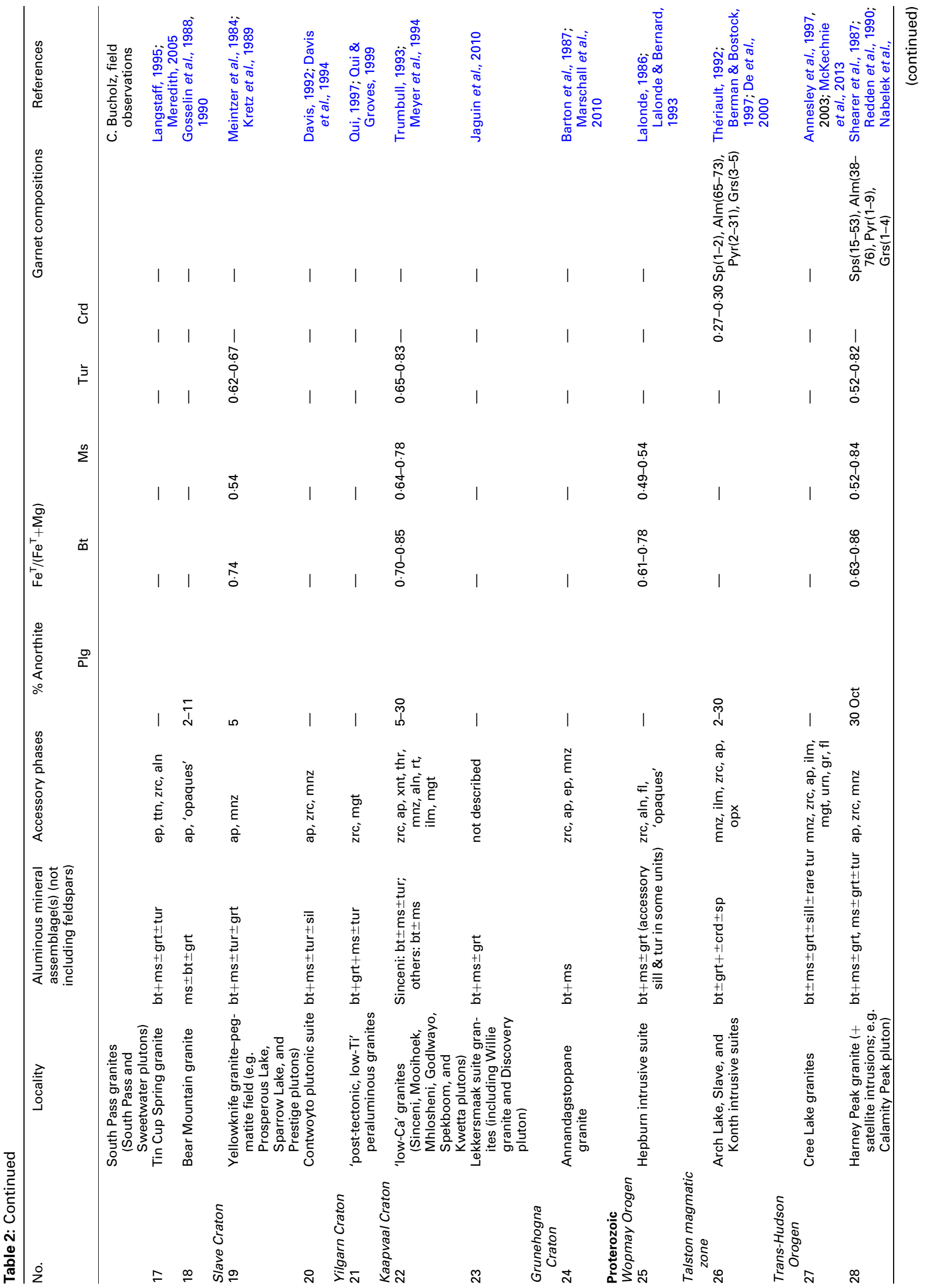




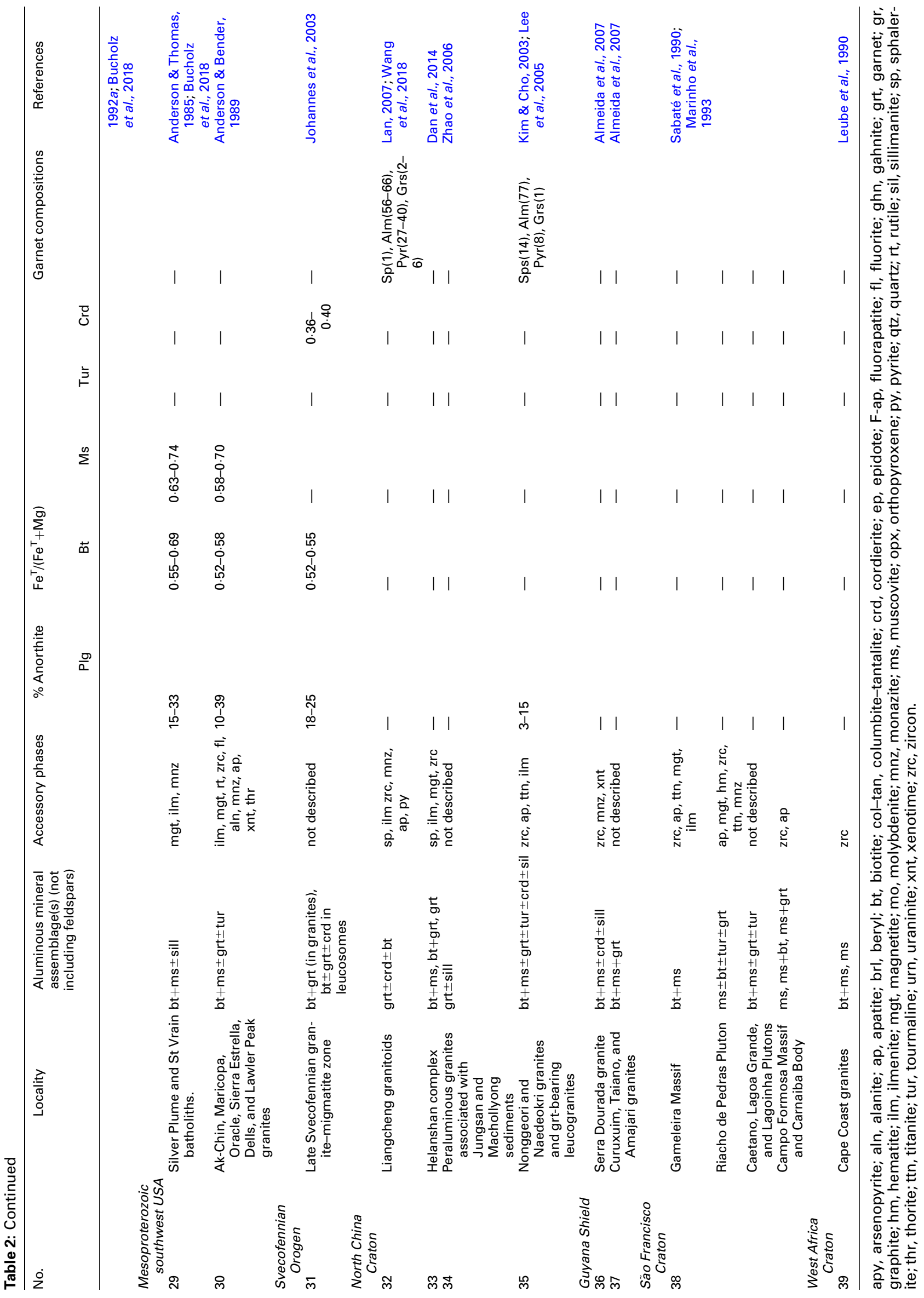



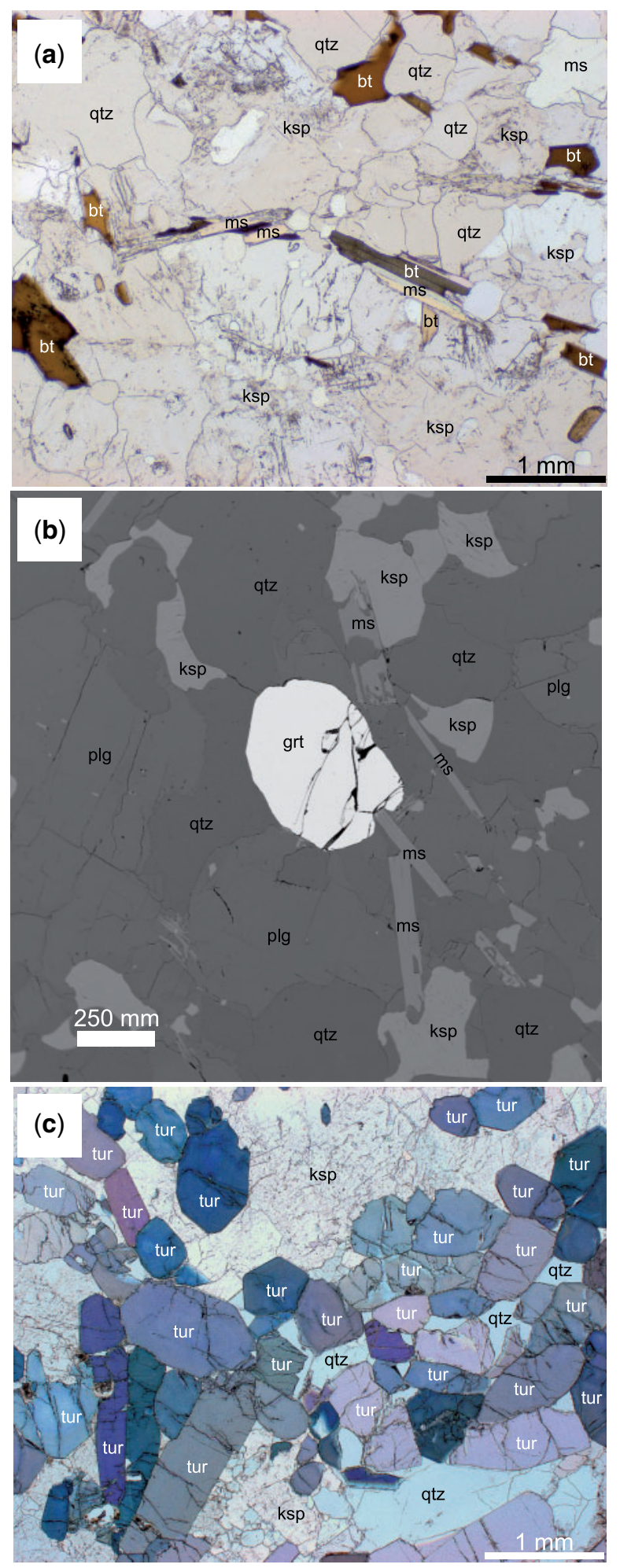

Fig. 4. Examples of mineralogy observed in Archean and Proterozoic SPGs. (a) Photomicrograph in plane-polarized light of biotite + muscovite granite from the Ghost Lake batholith (sample E19-8). (Note interlocking growth of biotite and muscovite.) (b) Back-scattered electron image of biotite + muscovite + garnet granite from the Ghost Lake batholith (sample F11-4). (c) Photomicrograph in cross-polarized light of tourmaline-rich granite from satellite intrusion associated with Harney Peak granite (sample HP-39a from Nabelek et al., 1992a, 1992b). bt, biotite; ksp, K-feldspar; ms, muscovite; plg, plagioclase; qtz, quartz; tur, tourmaline. merits a paper unto itself (e.g. Clarke, 1981; Clemens \& Wall, 1988; Zen, 1988; Holtz et al., 1992), we focus our discussion on an overview of Archean and Proterozoic SPG phase assemblages and mineral chemistry between these temporally distinct groups, which can inform our understanding of their intensive parameters during crystallization, whether they changed across the Archean-Proterozoic transition, and the implications these differences have for their sedimentary source material across this transition. We summarize reported mineral assemblages (including accessory phases) and compositions (when available) in Table 2.

All of the SPGs considered here contain biotite and/ or muscovite and sometimes other peraluminous minerals, dominantly garnet (Figs $3 c$, d and $4 a$, b). In addition, many include major to accessory minerals such as cordierite, aluminosilicates, tourmaline, or beryl, typical of SPGs (Tables 1 and 2; Fig. 4c). Within certain SPG plutons, zoning in mineralogy and composition is observed. For example, the Ghost Lake batholith, which has been the subject of a detailed study by Breaks \& Moore (1992), demonstrates mineralogical zoning from west to east from a more primitive biotite + cordierite granite to a highly evolved garnet + muscovite ( \pm tourmaline \pm beryl) granite. This was interpreted as the petrological and geochemical consequences of in situ differentiation (Breaks \& Moore, 1992). Another example of a zoned intrusion is the Harney Peak granite, where biotite is the dominant ferromagnesian mineral in the core of the pluton, whereas tourmaline dominates along the perimeter, as well as in satellite intrusions (Nabelek et al., 1992a). (Nabelek et al. 1992a) ascribed this difference in mineralogy to different source regions for the biotite- versus tourmalinebearing granites, as well as extents of melting. The biotite granites were proposed to have formed through high extents of biotite dehydration melting of immature greywackes, whereas the tourmaline granites (see example in Fig. 4c) were concluded to have formed through a lower extent of melting of metapelites, producing melts with high boron concentrations.

\section{Biotite}

Other than feldspar, biotite is generally the dominant aluminous mineral in the SPGs considered here and becomes rare to absent only in the more evolved leucogranites or tourmaline-dominated granites. Biotites from SPGs of all ages are more aluminous than members of the phlogopite-annite solid solution with significant eastonite-siderophyllite components (AbdelRahman, 1994; Bucholz et al., 2018). With the limited dataset available, no distinctions in major and minor elements in biotite (e.g. $\mathrm{TiO}_{2}$, halogens, etc.) from Archean and Proterozoic SPGs are observed, except for $\mathrm{Fe}^{\top} / \mathrm{Mg}$ ratios. Biotite $\mathrm{Fe}^{\top} / \mathrm{Mg}$ (where $\mathrm{Fe}^{\top}=\mathrm{Fe}^{2+}+\mathrm{Fe}^{3+}$ ) ratios are highly sensitive to oxygen fugacity $\left(f_{\mathrm{O}_{2}}\right)$ during crystallization, with higher values being stable at lower $f_{\mathrm{O}_{2}}$ (Wones \& Eugster, 1965; Czamanske \& 


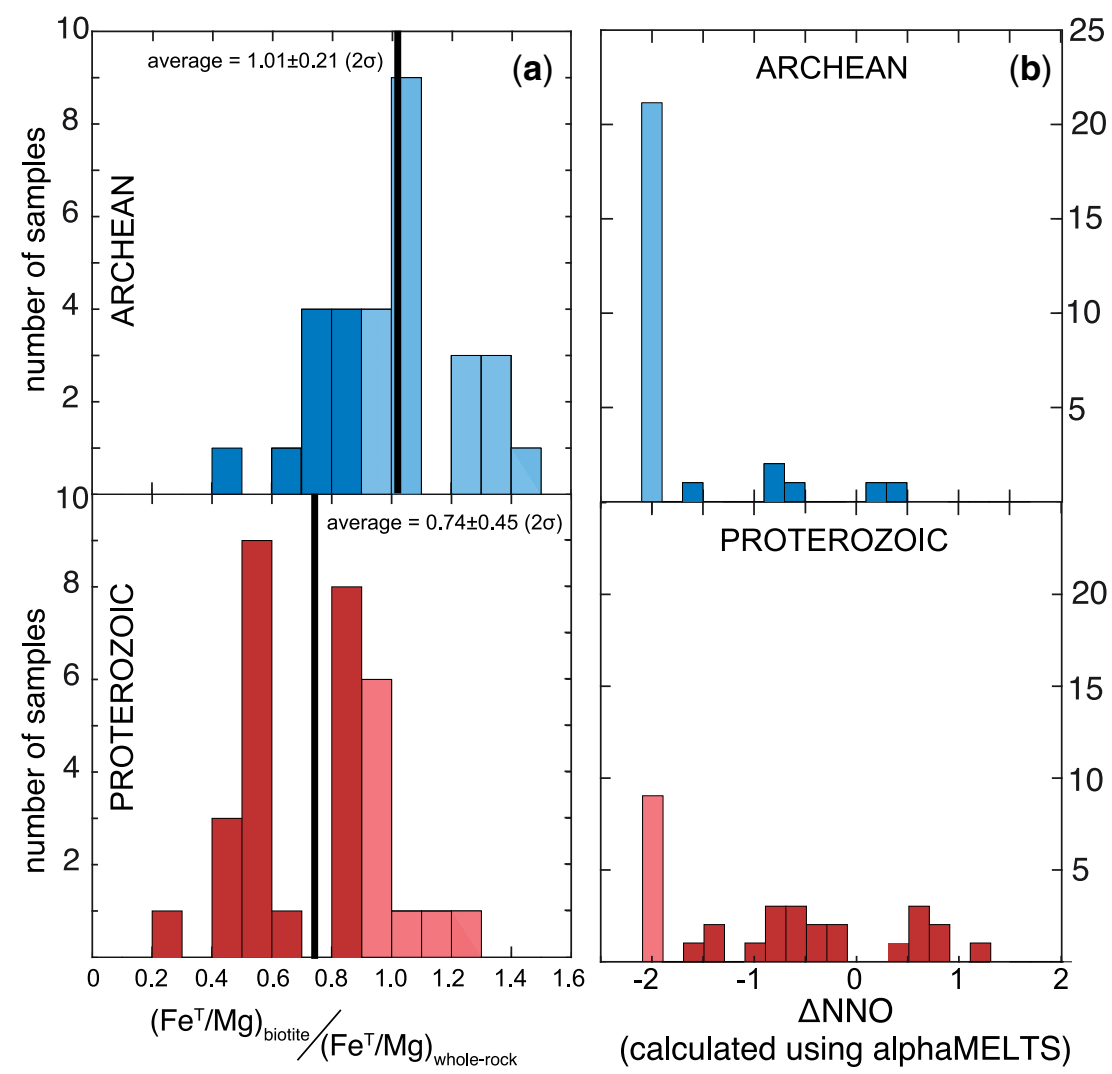

Fig. 5. Histograms of (a) $\mathrm{Fe}^{\top} / \mathrm{Mg}$ biotite-WR (whole-rock) partition coefficient [ $\left.K(\mathrm{bt}-\mathrm{WR})\right]$ and (b) calculated oxygen fugacity (relative to the Ni-NiO buffer) for Archean and Proterozoic SPGs using the method of Bucholz et al. (2018), which utilizes biotite and bulkrock compositions and alphaMELTS modeling. In (a) and (b) samples in lighter blue and red indicate those not amenable to modeling via alphaMELTS [owing to $K(\mathrm{bt}-\mathrm{WR})>0.9$; see Bucholz et al., 2018, for details]. For these samples, although a specific $f_{\mathrm{O}_{2}}$ could not be calculated, their elevated $K(\mathrm{bt}-\mathrm{WR}$ ) values impose a maximum limit of 2 log units below the $\mathrm{Ni}-\mathrm{NiO}$ buffer (NNO - 2).

Wones, 1973; Ague \& Brimhall, 1988). This arises as a result of the breakdown of the annite component in biotite with increasing $f_{\mathrm{O}_{2}}$ to produce K-feldspar, magnetite (or hematite component in hemo-ilmenite or $\mathrm{Fe}_{2} \mathrm{O}_{3}$ component in the melt), and $\mathrm{H}_{2} \mathrm{O}$ via a reaction such as

$\mathrm{KFe}_{3}^{2+} \mathrm{AlSi}_{3} \mathrm{O}_{10}(\mathrm{OH})_{2}+\mathrm{O}_{2} \mathrm{KAISi}_{3} \mathrm{O}_{8}+\mathrm{Fe}_{3} \mathrm{O}_{4}+\mathrm{H}_{2} \mathrm{O}$ annite $+\mathrm{O}_{2}$ à $\mathrm{K}-$ feldspar + magnetite

(solid or component in melt) + water vapor

Therefore, as $f_{\mathrm{O}_{2}}$ increases in a melt the total percentage of the $\mathrm{Fe}$ in the bulk system (i.e. melt + crystals) hosted within biotite will decrease as $\mathrm{Fe}^{3+}$ is preferentially partitioned into an oxide phase or the melt. As such, the $\mathrm{Fe}^{\top} / \mathrm{Mg}$ partition coefficient between biotite and whole-rock $\left[K_{b t-w r}^{F e^{T} / M g}=\left(\mathrm{Fe}^{T} / \mathrm{Mg}\right)_{\text {biotite }} /\right.$ $\left(F e^{T} / M g\right)_{\text {whole-rock }}$ ] decreases as $f_{O_{2}}$ increases (Bucholz et al., 2018). If independent estimates of temperature, pressure, and water activity are available, quantitative estimates of $f_{\mathrm{O}_{2}}$ can be obtained through thermodynamic modeling using alphaMELTS software (Smith \& Asimow, 2005).

Developing and using this method, Bucholz et al. (2018) modeled variations in $\mathrm{Fe}^{\top} / \mathrm{Mg}$ ratios in biotite from Archean and Proterozoic SPGs to understand whether they were characterized by differences in $f_{\mathrm{O}_{2}}$ during crystallization. They found that the average $K_{b t-b u l k}^{F e^{T} / M g}$ for Archean SPGs was $1.01 \pm 0.21$ versus $0.74 \pm 0.45$ for Proterozoic granites (Fig. 5a). The majority $(>80 \%)$ of Archean SPGs considered in the study crystallized at $f_{\mathrm{O}_{2}}$ values near the maximum stability of graphite in equilibrium with a water-saturated $\mathrm{C}-\mathrm{O}-\mathrm{H}$ fluid, whereas only $\sim 40 \%$ of the Proterozoic samples did. The other Proterozoic samples crystallized at higher $f_{\mathrm{O}_{2}}$ values [up to one log unit above the $\mathrm{Ni}-\mathrm{NiO}$ (NNO) buffer; Fig. 5b]. The simplest explanation for this observation is that the sediments from which Archean SPGs were derived had lower bulk redox states than the more oxidized Proterozoic SPGs, possibly reflecting the deposition of Archean SPG source rock sediments under lower partial pressures of atmospheric $\mathrm{O}_{2}$ prior to the GOE.

For example, $\mathrm{Fe}$ and $\mathrm{S}$, two of the dominant redoxsensitive elements in sediments, are characterized by different bulk redox states in Archean versus Proterozoic sediments. $\mathrm{Fe}$ in Archean sediments is dominantly ferrous and $S$ is hosted in sulfides, mainly pyrite, as $\mathrm{S}^{-1}$. In contrast, Proterozoic sediments are characterized by the proliferation of red beds stained by ferric Fe (Holland, 1984) and the onset of sulfate 
$\left(S^{6+}\right.$-bearing) deposits (Chandler, 1988). Thus, the variation in $f_{\mathrm{O}_{2}}$ of SPGs derived from sedimentary rocks deposited on either side of the GOE may reflect this change in $\mathrm{Fe}$ and $\mathrm{S}$ speciation. Although organic carbon is present in both Archean and Proterozoic sedimentary rocks and certainly exerted a reducing influence on Archean and Proterozoic SPG $f_{\mathrm{O}_{2}}$, it was probably the bulk redox state of the sediments that ultimately fixed the $f_{\mathrm{O}_{2}}$ of SPG magmas. In particular, although the cumulative preserved thicknesses of black shales in the Paleoproterozoic to Mesoproterozoic reached a peak in Earth history, the total organic carbon in these shales $(<5 \mathrm{wt} \%)$ was on average lower than at other times in Earth history (up to $\sim 30 \%$ in the Phanerozoic; Condie et al., 2001; Och \& Shields-Zhou, 2012). The simultaneous decrease in the organic carbon content of sediments (by weight per cent) and increase in amount of other oxidized sedimentary material may explain the relatively elevated $f_{\mathrm{O}_{2}}$ of Proterozoic SPGs as compared with Phanerozoic and Archean SPGs. Notably, however, many SPGs from both the Archean and Proterozoic crystallized at $f_{\mathrm{O}_{2}}$ values controlled by reduced carbon in their source region (samples at NNO - 2 in Fig. 5b), suggesting that burial of organic carbon in the sedimentary source regions for the SPGs has exerted an important control on the $f_{\mathrm{O}_{2}}$ of the SPGs across the transition (and indeed also for Phanerozoic SPGs; Flood \& Shaw, 1977; Blevin \& Chappell, 1992; Nabelek, 2019).

\section{White mica}

White mica is a common mineral in SPGs and can be either primary or secondary in origin. Primary white mica occurs as large euhedral books or phenocrysts (Fig. 4a), whereas secondary white mica shows textural relationships suggesting that it formed through the breakdown of feldspars, biotite, or other aluminosilicates during cooling and potential ingress of fluids (Miller, 1981). In addition to textural arguments, primary versus secondary white mica can be identified based on its chemistry. Miller (1981) suggested that magmatic white mica is consistently richer in $\mathrm{Ti}, \mathrm{Na}$, and $\mathrm{Al}$, but poorer in $\mathrm{Mg}$ and $\mathrm{Si}$, than secondary white mica. Bucholz et al. (2018) compiled and screened existing white mica compositional data for Archean and Proterozoic SPGs. In both the Archean and Proterozoic granites, white mica does not occur as pure end-member muscovite $\left[\mathrm{K}_{2} \mathrm{Al}_{4}\left(\mathrm{Si}_{6} \mathrm{Al}_{2} \mathrm{O}_{20}\right)\right]$ but rather exhibits solid solution towards paragonite $\left[\mathrm{Na}_{2} \mathrm{Al}_{4}\left(\mathrm{Si}_{6} \mathrm{Al}_{2} \mathrm{O}_{20}\right)(\mathrm{OH})_{4}\right]$ and celadonite $\left[\mathrm{K}_{2} \mathrm{Al}_{2}(\mathrm{Fe}, \mathrm{Mg})_{2}\left(\mathrm{Si}_{8} \mathrm{O}_{20}\right)(\mathrm{OH})_{4}\right]$ (Bucholz et al., 2018). Primary white mica was identified in all SPG samples from that study and no systematic compositional differences in white mica (e.g. Na contents, halogens, etc.) from Archean and Proterozoic SPGs were observed.

\section{Garnet}

Garnets in SPGs display variable compositions from one intrusion to another, mostly in relationship to Fe:Mg:Mn ratios. In both Archean and Proterozoic
SPGs, garnets are almandine-spessartine solid solutions, having only a minor pyrope and grossular component (generally $<10 \mathrm{~mol}$. \%; Table 2). Some garnets in the highly evolved SPGs from both the Archean and Proterozoic can attain spessartine-rich compositions (e.g. $50-60 \mathrm{~mol} \%$ ), probably owing to high $\mathrm{Mn} / \mathrm{Mn}+$ $\mathrm{Fe}^{2+}+\mathrm{Mg}$ ) in evolved peraluminous melts. However, no systematic differences in composition between Archean and Proterozoic samples are observed in the existing data. Garnet in SPGs can have a number of origins, including direct crystallization from the granitic melt (Hall \& Tyler, 1965; Joyce, 1973; Green, 1977), derivation from restitic material (White \& Chappell, 1977; Stevens et al., 2007; Villaros et al., 2009) or surrounding host rock (Allan \& Clarke, 1981), or reaction between early formed phases and silicate melt (e.g. liquid + biotite $\rightarrow$ garnet + muscovite; Miller \& Stoddard, 1981). Combined careful textural, petrographic, and geochemical studies are required to determine the origin for garnet in SPGs, which are currently lacking for SPGs from the Archean and Paleo- to Mesoproterozoic. Therefore, at this time using garnet compositions to understand either the crystallization conditions or the characteristics of the source rocks of these granites is difficult, but would provide a fruitful avenue for future study.

\section{Other peraluminous indicator minerals and accessory phases}

Other peraluminous indicator minerals present in both Archean and Proterozoic SPGs include cordierite, tourmaline, sillimanite, and beryl. Cordierite is found in less evolved granites (e.g. parts of the Ghost Lake batholith, the Treelined Lake complex, the Talston Magmatic Zone, and the Liangcheng granites) (Breaks \& Moore, 1992; Pan \& Breaks, 1997; De et al., 2000; Wang et al., 2018). In contrast, tourmaline is a phase dominantly found coexisting with muscovite and garnet in more evolved SPGs and only rarely with biotite (Fig. 4c; Breaks \& Moore, 1992; Nabelek et al., 1992a). The water content of the melt is probably the determining factor controlling whether tourmaline or biotite crystallizes from a B-bearing strongly peraluminous melt. For example, Scaillet et al. (1991) found that in a strongly peraluminous granitic melt biotite is the stable liquidus phase at high water activities (when the mole fraction of water in the coexisting vapor phase is $<0.7$ ), whereas tourmaline is stable only at lower water activities. Elevated $\mathrm{Ti}$ contents in strongly peraluminous melts may also stabilize biotite over tourmaline (Nabelek, 2019). No systematic differences in either abundances or compositions of these phases are observed between Archean and Proterozoic SPGs based on existing, albeit limited data.

Dominant accessory phases in the SPGs include (fluor-)apatite, monazite, thorite, zircon, titanite, allanite, spinel, uraninite, graphite, ilmenite, magnetite, and rutile. Notably, Archean SPGs predominantly contain ilmenite as the sole stable $\mathrm{Fe}-\mathrm{Ti}$ oxide [although 
magnetite has been described in granites from the Yilgarn and Kaapvaal craton (Trumbull, 1993; Qui, 1997)], whereas magnetite is found in a number of the Proterozoic SPGs (e.g. Cree Lake granites, Mesoproterozoic granites of the southwestern USA, the Helanshan complex, and SPGs of the Transamazonian Orogeny). The presence of magnetite in these granites indicates that they crystallized at sufficiently elevated $f_{\mathrm{O}_{2}}$ for magnetite to be a stable crystallizing phase (e.g. Ishihara, 1977). As discussed in the section on biotite chemistry, this transition in $f_{\mathrm{O}_{2}}$ values of crystallization may reflect a shift in the bulk redox state of the sedimentary source rocks across the GOE.

\section{WHOLE-ROCK MAJOR AND TRACE ELEMENT CHEMISTRY}

Whole-rock major and trace element chemistry for SPGs can be difficult to interpret in the framework of melt compositions because of the potential for restitic material to be entrained in the granitic melt during extraction from the source (White \& Chappell, 1977; Chappell et al., 1987; Stevens et al., 2007). [However, see Wall et al. (1987) and Clemens (1989) for points raised against the restite model.] In addition, melt compositions, and in particular some trace element concentrations, are highly sensitive to the degree of melting, the source rock composition, and the presence and abundance of accessory minerals in the restite. With these caveats in mind, we present an analysis of the whole-rock chemistry of both Archean and Proterozoic SPGs, both compiled from the existing literature and newly acquired data. A complete dataset with references is available in Supplementary Data Table S1; supplementary data are available for downloading at http:// www.petrology.oxfordjournals.org. Newly acquired major and trace element whole-rock chemistry for 50 samples from the St Vrain and Silver plume granites (Colorado, USA), Mt Owen batholith (Wyoming, USA), and the Superior Craton was obtained via X-ray fluorescence (XRF) at Caltech $(n=47)$ and Washington State University $(n=3)$. Sample information (i.e. locality, lithology, sampling GPS coordinates) for the newly acquired data is provided in Supplementary Data Table S2. Whole-rock sample preparation and analytical methods are described in the Supplementary Data. From an initially larger dataset including all available whole-rock data from the localities listed in Table 1, we culled the samples to include only whole-rock compositions normalized to $100 \%$ on an anhydrous basis that contained $68-80$ wt $\% \mathrm{SiO}_{2}$ and $<5 \mathrm{wt} \% \mathrm{FeO}+\mathrm{MgO}+$ $\mathrm{TiO}_{2}$, and had $\mathrm{ASI}>1.1 ; 586$ Archean and 255 Proterozoic whole-rock analyses of SPGs are considered.

To frame our discussion, a brief overview of partial melting of metasedimentary rocks is merited. We direct the reader to more detailed discussions in the literature, as a wealth of work has been done on this subject, through both experimental studies (Le Breton \&
Thompson, 1988; Vielzeuf \& Holloway, 1988; Patiño Douce \& Johnston, 1991; Icenhower \& London, 1995; Vielzeuf \& Montel, 1994; Montel \& Vielzeuf, 1997; Stevens et al., 1997; Patiño Douce \& Harris, 1998; Pickering \& Johnston, 1998) and detailed geochemical modeling (e.g. Clemens \& Vielzeuf, 1987; Harris et al., 1993, 1995; Sylvester, 1998; Spear et al., 1999; Nabelek, 2019). A critical factor controlling the amount of melt produced during the partial melting of metasedimentary rocks is the presence or absence of excess fluid (see Clemens \& Vielzeuf, 1987, for a detailed discussion). In both the presence and absence of excess fluid, the primary melting reactions that occur involve the breakdown of either muscovite or biotite:

$$
\begin{aligned}
& \text { muscovite }+ \text { quartz }+ \text { plagioclase }(+ \text { fluid }) \\
& =\text { aluminosilicate }\left(\mathrm{Al}_{2} \mathrm{SiO}_{5}\right)+\text { melt } \\
& \text { biotite }+ \text { aluminosilicate }\left(\mathrm{Al}_{2} \mathrm{SiO}_{5}\right)+\text { quartz } \\
& \quad+\text { plagioclase }(+ \text { fluid }) \\
& \quad=\text { garnet }+\mathrm{K}-\text { feldspar }+ \text { melt }
\end{aligned}
$$

In equations (2) and (3), if excess fluid is present (indicated by '+ fluid' in parentheses), the reactions proceed until one of the phases on the left-hand side of the reaction is exhausted. When fluid is absent, sometimes referred to as dehydration melting, the amount of either muscovite [equation (2)] or biotite [equation (3)] in the source controls the amount of melt produced. Quantitative modeling of these reactions to determine trace element concentrations in the derivative melts will strongly rest upon assumptions concerning equilibrium between the melt and solid phases and the choice of partition coefficients used (e.g. Harris et al., 1993). For trace elements that reside predominantly in major phases (e.g. $\mathrm{Rb}, \mathrm{Sr}$, and $\mathrm{Ba}$ in micas and feldspars), it is reasonable to infer that trace element modeling of biotite- and muscovite-breakdown reactions [equations (2) and (3)] will generally capture the range of compositions produced in nature. Other trace elements that predominantly reside in accessory phases (e.g. REE, Zr, Th, and $\mathrm{Nb}$ ) are dominantly controlled by dissolution of these minor phases, which in turn are dependent on the solubility of the phases in various melt compositions and, potentially, incomplete separation between the melt and restitic minerals (e.g. Barbero et al., 1995; Ayres \& Harris, 1997; Zeng et al., 2005a, 2005b). Trace element modeling based on the reactions in equations (2) and (3), therefore, is restricted to $\mathrm{Rb}, \mathrm{Sr}$, and $\mathrm{Ba}$. ( $\mathrm{Zr}$, however, can potentially yield information on maximum temperatures of melting through zircon saturation temperature modeling as discussed in more detail below.)

Archean and Proterozoic SPGs are relatively similar in terms of most major element concentrations, because as a whole they represent near minimum melts in the peraluminous haplogranite system. Most $(>90 \%)$ of the analyses fall within the following compositional brackets: $13.5-17.0 \mathrm{wt} \% \mathrm{Al}_{2} \mathrm{O}_{3},<0.4 \mathrm{wt} \% \mathrm{TiO}_{2}, 0.3-$ $2.5 \mathrm{wt} \% \mathrm{CaO}$, and $3-7$ wt \% $\mathrm{Na}_{2} \mathrm{O} . \mathrm{K}_{2} \mathrm{O}$ contents are 

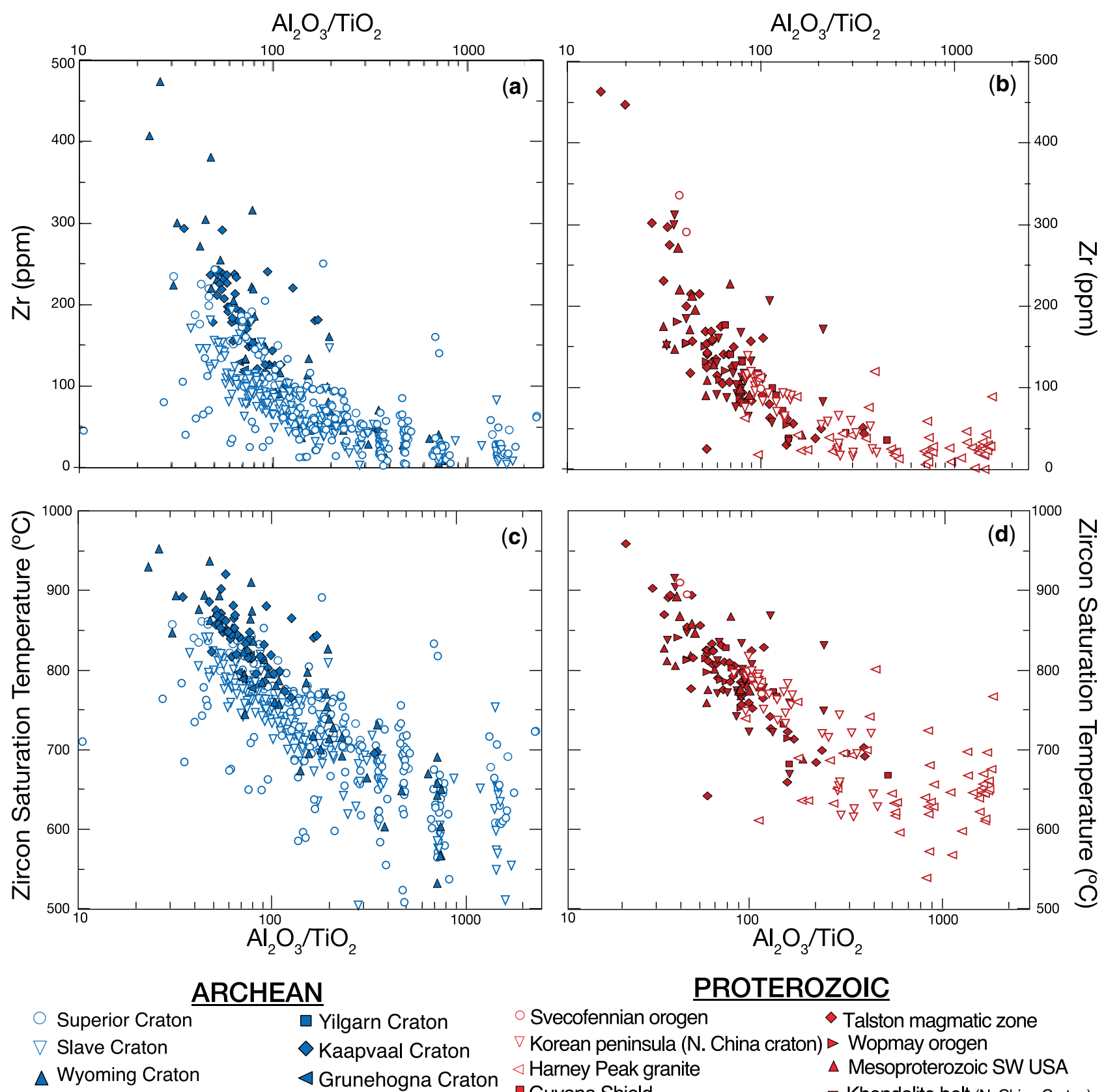

ARCHEAN

$\nabla$ Slave Craton

$\triangle$ Wyoming Craton

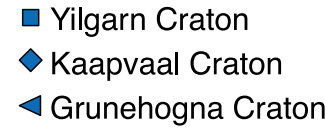

$\square$ Yilgarn Craton
$\diamond$ Kaapvaal Craton
$\triangleleft$ Grunehogna Craton

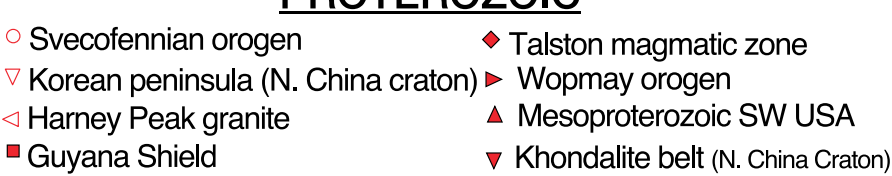

Fig. 6. Summary of whole-rock geochemistry indicative of temperature of melting. $\mathrm{Zr}(\mathrm{a}, \mathrm{b})$ and zircon saturation temperature (c, d) for Archean $(a, c)$ and Proterozoic $(b, d) S P G s$ versus whole-rock $\mathrm{Al}_{2} \mathrm{O}_{3} / \mathrm{TiO}_{2}$. Zircon saturation temperature is calculated using distribution coefficient of $\mathrm{Zr}$ between zircon and melt as parameterized by Boehnke et al. (2013). Filled symbols are used for localities that generally plot at higher $\mathrm{Zr}$ contents and zircon saturation temperatures, and lower $\mathrm{Al}_{2} \mathrm{O}_{3} / \mathrm{TiO}_{2}$ ratios.

more variable, between 1 and 8 wt \%. According to the granite classification of Frost et al. (2001), the SPGs considered here span a range of compositions from magnesian to ferroan and calcic to alkalic. The only consistent compositional features (as defined by the compositional constraints imposed on the compilation) are that they are strongly peraluminous and have high $\mathrm{SiO}_{2}$ contents (70-80 wt \%). Although there is variability between localities in both Archean and Proterozoic SPGs, their major and trace element concentrations are similar to those observed in Phanerozoic SPGs (see
Sylvester, 1998; Nabelek, 2019). However, several major and trace element characteristics of Archean and Proterozoic samples indicative of temperature of melting and source lithology merit discussion.

\section{$\mathrm{Al}_{2} \mathrm{O}_{3} / \mathrm{TiO}_{2}$ and $\mathrm{Zr}$-melting temperatures}

In an analysis of experimental studies on partial melting of sediments, Sylvester (1998) found that $\mathrm{Al}_{2} \mathrm{O}_{3} / \mathrm{TiO}_{2}$ values in the partial melts are primarily controlled by the temperature of melting. Whereas $\mathrm{Al}_{2} \mathrm{O}_{3}$ contents remain relatively constant in partial melts owing to the 
stability of refractory aluminous phases (e.g. plagioclase, garnet, aluminosilicates) in the restite, $\mathrm{TiO}_{2}$ contents will increase with increasing temperatures owing to the breakdown of Ti-bearing phases such as biotite and ilmenite. If whole-rock SPG compositions are considered pure partial melts (i.e. they have not experienced mixing with another melt, assimilation, or fractional crystallization) their whole-rock $\mathrm{Al}_{2} \mathrm{O}_{3} / \mathrm{TiO}_{2}$ should reflect the temperature of melt generation. If this assumption is valid, SPGs produced as a result of partial melting at higher temperatures will have lower $\mathrm{Al}_{2} \mathrm{O}_{3} / \mathrm{TiO}_{2}$ on average than those produced at lower temperatures. Similarly, $\mathrm{Zr}$ concentrations and calculated zircon saturation temperatures have also been used as an indicator of magmatic temperature for silicic magmas (e.g. Watson \& Harrison, 1983; Miller et al., 2003; Boehnke et al., 2013). Zr solubility in magmas is primarily a function of magmatic composition and temperature, with higher concentrations of $\mathrm{Zr}$ capable of being dissolved in melts at higher $(\mathrm{Na}+\mathrm{K}+2 \mathrm{Ca}) /$ $(\mathrm{Al} \times \mathrm{Si}$ ) ratios and higher temperatures (Watson \& Harrison, 1983; Boehnke et al., 2013). If a rock is saturated in zircon, calculated zircon saturation temperatures using whole-rock $\mathrm{Zr}$ contents provide a maximum magmatic temperature estimate (Miller et al., 2003).

These two geochemical variables (whole-rock $\mathrm{Al}_{2} \mathrm{O}_{3}$ / $\mathrm{TiO}_{2}$ ratios and calculated zircon saturation temperatures) portray a consistent story concerning magmatic temperatures in SPGs. Both whole-rock $\mathrm{Zr}$ concentrations and zircon saturation temperatures covary with whole-rock $\mathrm{Al}_{2} \mathrm{O}_{3} / \mathrm{TiO}_{2}$ ratios (Fig. 6). That is, Archean and Proterozoic SPGs with low $\mathrm{Al}_{2} \mathrm{O}_{3} / \mathrm{TiO}_{2}$ ratios $(<100)$ have higher $\mathrm{Zr}$ contents (generally $>100 \mathrm{ppm}$ ) and $\mathrm{Zr}$ saturation temperatures (average $807 \pm 105^{\circ} \mathrm{C}, 2 \sigma$ ), whereas SPGs with $\mathrm{Al}_{2} \mathrm{O}_{3} / \mathrm{TiO}_{2}$ ratios $>100$ have lower $\mathrm{Zr}$ contents (generally $<100 \mathrm{ppm}$ ) and $\mathrm{Zr}$ saturation temperatures $\left(688 \pm 145^{\circ} \mathrm{C}, 2 \sigma\right)$ (Fig. 6). Whether these temperatures reflect the primary temperatures of partial melting versus secondary temperatures during cooling (and fractional crystallization of biotite and zircon) is unclear (see Finger \& Schiller, 2012). However, SPGs with high $\mathrm{Zr}$ saturation temperatures and low $\mathrm{Al}_{2} \mathrm{O}_{3} / \mathrm{TiO}_{2}$ ratios certainly obtained elevated temperatures and were probably derived through relatively high-temperature melting above the biotite-dehydration curve $\left(>800^{\circ} \mathrm{C}\right)$. In contrast, SPGs with low $\mathrm{Zr}$ concentrations and zircon saturation temperatures and high $\mathrm{Al}_{2} \mathrm{O}_{3} / \mathrm{TiO}_{2}$ whole-rock ratios may have formed under conditions of relatively cool, muscovite-dehydration melting (which occurs between 650 and $725^{\circ} \mathrm{C}$ at $0.4-1.0 \mathrm{GPa}$ ). These 'cooler' peraluminous granitic melts would have been saturated in zircon in the source (along with potentially other refractory restitic trace phases such as monazite or apatite).

Sylvester (1998) compared whole-rock $\mathrm{Al}_{2} \mathrm{O}_{3} / \mathrm{TiO}_{2}$ ratios in SPGs from different Phanerozoic orogens with known metamorphic histories to test the idea that 'lowtemperature' versus 'high-temperature' orogens would preserve SPGs with different whole-rock compositions indicative of temperature of melting. His observations suggested that a distinction may be made between SPGs from (1) 'low-temperature, high-pressure' collisions [e.g. the Alps and Himalayas, where small- to moderate-volume 'cool', post-collisional SPGs formed by decompression melting of over-thickened crust ( $>50 \mathrm{~km}$ thick) heated by in situ decay of radiogenic elements] and (2) high-temperature collisions (e.g. the Hercynides or the Lachlan fold belt) in which large-volume, 'hot' post-collisional SPGs formed by mantlederived heating of crust $\leq 50 \mathrm{~km}$ thick after lithospheric delamination. Indeed, Sylvester (1998) found that Phanerozoic SPGs from 'low-' and 'high-temperature' collisions tended to have high and low $\mathrm{Al}_{2} \mathrm{O}_{3} / \mathrm{TiO}_{2}$ ratios, respectively. Archean and Proterozoic SPGs span the range in $\mathrm{Al}_{2} \mathrm{O}_{3} / \mathrm{TiO}_{2}$ values observed by Sylvester (1998) for Phanerozoic SPGs (20-500), although some samples in both temporal groups extend to higher $\mathrm{Al}_{2} \mathrm{O}_{3} / \mathrm{TiO}_{2}$ values (up to 2000; Fig. 6). [It should be noted that the samples with the highest $\mathrm{Al}_{2} \mathrm{O}_{3} / \mathrm{TiO}_{2}$ values are primarily due to low $\mathrm{TiO}_{2}$ concentrations with limited reported significant digits (e.g. 0.01 and $0.02 \mathrm{wt} \%)$, giving rise to near-vertical trends in $\mathrm{Zr}$ or zircon saturation temperature versus $\mathrm{Al}_{2} \mathrm{O}_{3} / \mathrm{TiO}_{2}$.]

For Archean SPGs, those from the Yilgarn, Kaapvaal, and Grunehogna Cratons (filled blue symbols) define a more tightly clustered range of values at lower $\mathrm{Al}_{2} \mathrm{O}_{3} / \mathrm{TiO}_{2}$ and higher $\mathrm{Zr}$ concentrations and zircon saturation temperatures than those from the Superior, Slave, and Wyoming cratons (open symbols), which display more variable values extending to lower $\mathrm{Zr}$ contents and higher $\mathrm{Al}_{2} \mathrm{O}_{3} / \mathrm{TiO}_{2}$ values (Fig. $6 \mathrm{a}$ and c). This geographical distinction is notable, as it suggests that the SPGs from the Yilgarn, Kaapvaal, and Grunehogna Cratons were derived predominantly through higher temperatures of melting $\left(>800^{\circ} \mathrm{C}\right)$. In contrast, SPGs from the Superior, Slave, and Wyoming cratons appear to have formed through cooler melting conditions $\left(<750^{\circ} \mathrm{C}\right)$. In the Proterozoic SPGs, the Harney Peak granite of the Trans-Hudson Orogeny (open left-pointing triangles) defines the high $\mathrm{Al}_{2} \mathrm{O}_{3} /$ $\mathrm{TiO}_{2}$ and low zircon saturation temperature end of the distribution of samples in our dataset (Fig. 6b and d), suggesting derivation at relatively low temperatures of melting. In contrast, the Proterozoic SPGs from the SW USA, the Talston magmatic zone, Guyana Shield, and Khondalite belt of north China (filled red symbols) define the low $\mathrm{Al}_{2} \mathrm{O}_{3} / \mathrm{TiO}_{2}$ end of the data array, suggestive of partial melting at higher temperatures. Although specific localities cluster towards high or low $\mathrm{Al}_{2} \mathrm{O}_{3} /$ $\mathrm{TiO}_{2}$ values, these variations occur in both Archean and Proterozoic SPGs. As such, this suggests that variations in temperatures of sediment melting and likely tectonic mechanisms of producing melting (e.g. burial during a collisional orogeny, mafic underplating, ridge subduction, etc.) were locality specific and tectonically viable from the Mesoarchean $(\sim 3.0 \mathrm{Ga})$ into the Paleoand Mesoproterozoic. 

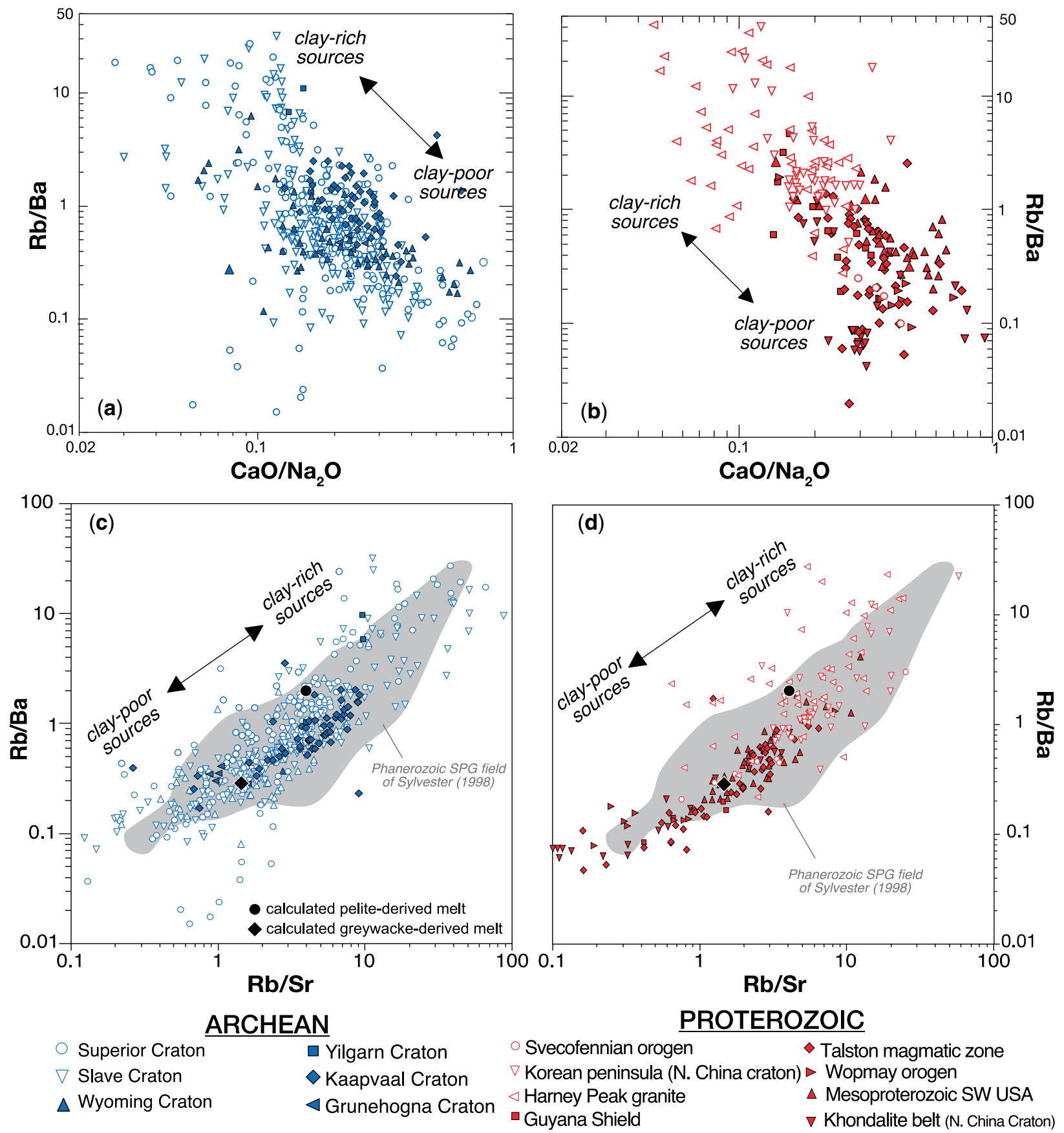

Fig. 7. Summary of bulk-rock geochemistry indicative of source rock lithology. $\mathrm{Rb} / \mathrm{Ba}$ versus $\mathrm{CaO} / \mathrm{Na}_{2} \mathrm{O}(\mathrm{a}, \mathrm{b}) \mathrm{and} \mathrm{Rb} / \mathrm{Sr}(\mathrm{c}, \mathrm{d})$ for Archean (a, c) and Proterozoic (b, d) SPGs. Symbols as in Fig. 5. In (c) and (d), calculated pelite- and greywacke-derived melts are from Sylvester (1998).

$\mathrm{CaO} / \mathrm{Na}_{2} \mathrm{O}, \mathrm{Rb} / \mathrm{Sr}$, and $\mathrm{Rb} / \mathrm{Ba}$-source lithologies In his analysis of partial melting experiments on metasedimentary rocks and SPG whole-rock compositions, Sylvester (1998) also demonstrated that $\mathrm{CaO} / \mathrm{Na}_{2} \mathrm{O}, \mathrm{Rb} /$ $\mathrm{Sr}$, and $\mathrm{Rb} / \mathrm{Ba}$ whole-rock values of SPGs could be used to understand variation in source lithologies. SPGs produced through partial melting of plagioclase-rich, claypoor sources (greywackes) will have higher $\mathrm{CaO} / \mathrm{Na}_{2} \mathrm{O}$ ratios than those produced through partial melting of clay-rich pelites owing to the contribution of $\mathrm{CaO}$ to the melt from plagioclase (Patiño Douce \& Johnston, 1991; Patiño Douce \& Beard, 1995). Extent of melting, pressure, and $\mathrm{H}_{2} \mathrm{O}$ activity will also affect these ratios; however, the abundance of plagioclase in the source lithology is the strongest control (Sylvester, 1998). The systematics of $\mathrm{Rb} / \mathrm{Sr}$ and $\mathrm{Rb} / \mathrm{Ba}$ ratios of $\mathrm{SPG}$ whole-rock compositions are slightly more complicated. Comprehensive partial melting modeling of various source materials suggest that two primary factors control $\mathrm{Rb} / \mathrm{Sr}$ and $\mathrm{Rb} / \mathrm{Ba}$ ratios (Harris \& Inger, 1992; Harris 


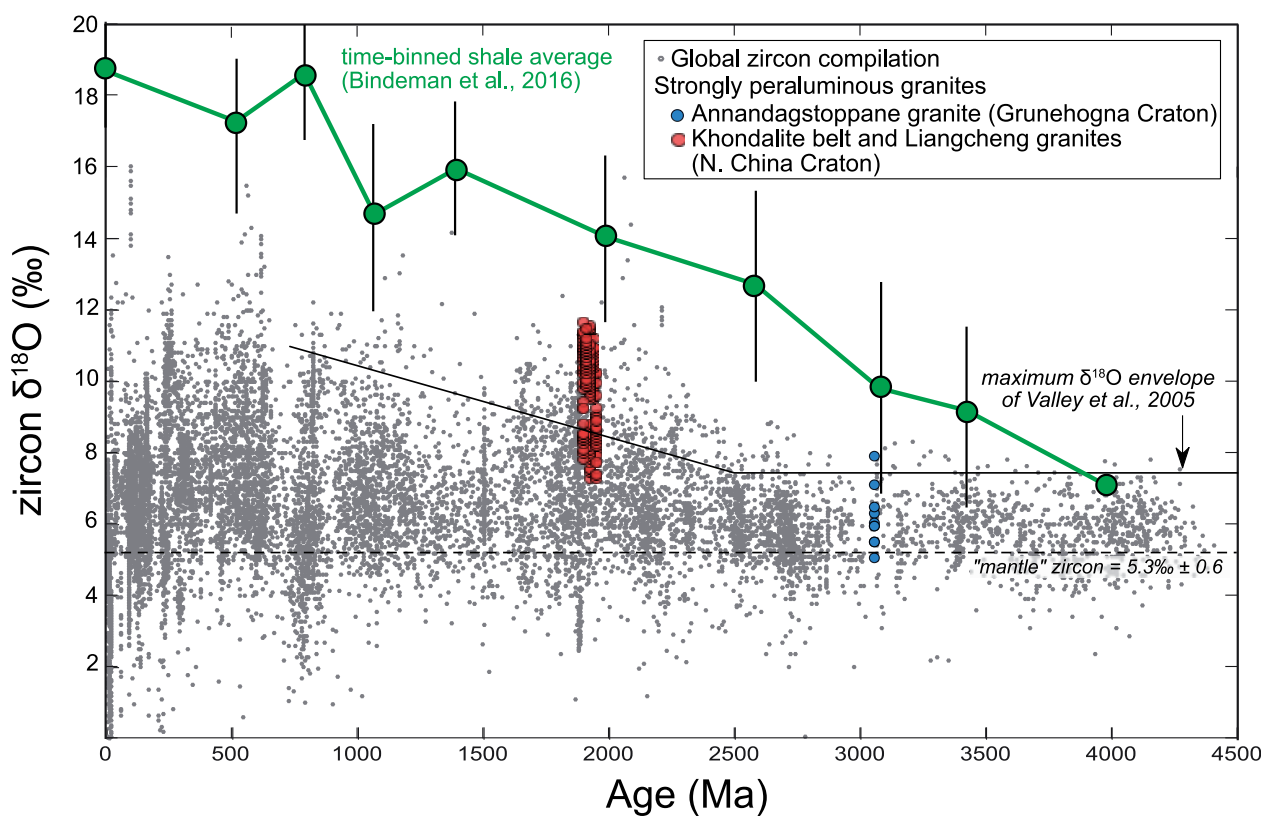

Fig. 8. Zircon and shale $\delta^{18} \mathrm{O}(\%)$ values with age (Ma). Global zircon compilation (grey dots) is from Spencer et al. (2017) and includes both detrital zircons and zircons separated from igneous rocks. Time binned averages of shale compositions are from Bindeman et al. (2016) with $1 \sigma_{\mathrm{SD}}$ errors on average. Data for the Archean Annandagstoppane granite (blue dots) are from Marschall et al. (2010), and for the Proterozoic granites from the Khondalite belt and Liangcheng granites of the North China Craton are from Dan et al. (2014) and Wang et al. $(2017,2018)$.

et al., 1993). First, vapor-absent melting produces higher $\mathrm{Rb} / \mathrm{Sr}$ and $\mathrm{Ba} / \mathrm{Sr}$ ratios in the partial melt owing to lower melt fractions and the presence of significant feldspar (both plagioclase and K-feldspar) in the restite, which will retain Sr. Second, muscovite- or biotite-rich, plagioclase-poor rocks (i.e. metapelites) will yield higher $\mathrm{Rb} / \mathrm{Sr}$ and $\mathrm{Rb} / \mathrm{Ba}$ ratios than plagioclase-rich, mica-poor sediments (i.e. greywackes) owing to higher $\mathrm{Rb}$ concentrations in the source rocks (Harris et al., 1993; Sylvester 1998). Sylvester (1998) pointed out that the $\mathrm{Rb} / \mathrm{Sr}$ and $\mathrm{Rb} / \mathrm{Ba}$ ratios of Phanerozoic SPGs generally fall on a loglinear array of increasing $\mathrm{Rb} / \mathrm{Sr}$ with $\mathrm{Rb} / \mathrm{Ba}$. In addition, he noted that SPGs with low $\mathrm{CaO} / \mathrm{Na}_{2} \mathrm{O}$ ratios generally have higher $\mathrm{Rb} / \mathrm{Sr}$ and $\mathrm{Rb} / \mathrm{Ba}$ ratios than do those with high $\mathrm{CaO} / \mathrm{Na}_{2} \mathrm{O}$ ratios, although there is some overlap. As such, Sylvester (1998) suggested that $\mathrm{Rb} / \mathrm{Sr}$ and $\mathrm{Rb} /$ Ba ratios in SPGs are dominantly controlled by the characteristics of the source rock, with higher $\mathrm{Rb} / \mathrm{Sr}$ and $\mathrm{Rb}$ / $B$ a ratios reflecting clay-rich sources.

In Archean and Proterozoic SPGs, whole-rock $\mathrm{CaO} /$ $\mathrm{Na}_{2} \mathrm{O}$ is negatively correlated with both $\mathrm{Rb} / \mathrm{Sr}$ and $\mathrm{Rb} / \mathrm{Ba}$ (Fig. 7a and b). In addition, whole-rock compositions of Archean and Proterozoic SPGs define a similar, positively correlated trend of $\mathrm{Rb} / \mathrm{Sr}$ and $\mathrm{Rb} / \mathrm{Ba}$ to the Phanerozoic SPG compilation presented by Sylvester (1998) (Fig. 7c and d). Localities with lower $\mathrm{CaO} / \mathrm{Na}_{2} \mathrm{O}$ values tend to have higher $\mathrm{Rb} / \mathrm{Sr}$ and $\mathrm{Rb} / \mathrm{Ba}$ ratios and vice versa, suggesting derivation from clay-rich and clay-poor source regions, respectively. For example, for the Proterozoic SPGs, the Harney Peak granite of the Trans-Hudson Orogeny (open left-pointing triangles) defines the low $\mathrm{CaO} / \mathrm{Na}_{2} \mathrm{O}$ and high $\mathrm{Rb} / \mathrm{Sr}$ and $\mathrm{Rb} / \mathrm{Ba}$ end of the distribution of samples in our dataset (Fig. 7b and d), suggesting derivation from clay-rich sources. In contrast, the Proterozoic SPGs from the SW USA, the Talston magmatic zone, Guyana Shield, and Khondalite belt of north China (filled red symbols) define the high-CaO/ $\mathrm{Na}_{2} \mathrm{O}$ and low $\mathrm{Rb} / \mathrm{Sr}$ and $\mathrm{Rb} / \mathrm{Ba}$ of the data array (Fig. 7b and $d$ ), suggestive of partial melting of greywacke-rich (i.e. clay-poor) source rocks. SPGs from other localities appear to have formed through melting of both plagioclase- and clay-rich source rocks, such as those from the Superior, Slave, and Wyoming cratons.

No systematic difference in the ranges or distributions of $\mathrm{CaO} / \mathrm{Na}_{2} \mathrm{O}, \mathrm{Rb} / \mathrm{Sr}$, or $\mathrm{Rb} / \mathrm{Ba}$ values is observed between Archean and Proterozoic SPG populations as a whole, suggesting that clay-rich and clay-poor sediments were present in the source rocks of both Archean and Proterozoic SPGs. Therefore, on a broad scale the sedimentary source regions for SPGs may have been similar in terms of maturity (i.e. clay component) across the Archean-Proterozoic transition. However, we recognize that this suggestion is based upon a relatively limited dataset of both Archean and Proterozoic SPGs (Fig. 7). A larger compilation of Archean and Proterozoic SPG whole-rock chemistry from more localities, in addition to quantitative trace element modeling of partial melting of specific representative source rocks, would be useful to explore this idea in greater detail.

\section{STABLE ISOTOPES}

Given the existing petrological and geochemical data indicating an origin through partial melting of 
metasedimentary rocks, Archean and Proterozoic SPGs should preserve stable (e.g. oxygen) and radiogenic isotope signatures suggesting derivation from weathered, continental material (e.g. elevated ${ }^{18} \mathrm{O} /{ }^{16} \mathrm{O}$ ratios and initial ${ }^{87} \mathrm{Sr} /{ }^{86} \mathrm{Sr}$ ratios). The available oxygen isotope data for the SPGs, however limited, clearly demonstrate this, as explained in detail below. We do not discuss the radiogenic isotope compositions of the SPGs because of the difficulties involved in their interpretation. Melts derived through the partial melting of metasedimentary rocks have complicated trace element and radiogenic isotope signatures owing (in part) to the disequilibrium nature of crustal anatexis at relatively low temperatures (e.g. Watson \& Harrison, 1983; Hammouda et al., 1996; Patiño Douce \& Harris, 1998; Knesel \& Davidson, 2002; Zeng et al., 2005a, 2005b). As a result of incomplete dissolution of accessory phases (e.g. apatite, monazite, or zircon), some trace elements (e.g. $\mathrm{Pb}$ and $\mathrm{REE}$ ) and radiogenic isotope characteristics (e.g. those of $\mathrm{Nd}, \mathrm{Pb}$, and $\mathrm{Hf}$ ) of anatectic melts are not representative of their source rock, but rather the degree to which the accessory phases have participated in the partial melting process (Hogan \& Sinha, 1991; Nabelek \& Glascock, 1995; Zeng et al., 2005a, 2005b; Farina et al., 2014; Tang et al., 2014). Therefore, the radiogenic isotope signatures of SPGs are controlled by two factors, which are difficult to untangle: (1) the age of the crust from which the sedimentary material was derived and subsequently melted (which is highly dependent on location and geological history); (2) disequilibrium melting during partial melting of refractory mineral phases. Therefore, we focus here on a review of existing oxygen isotope data, as other stable isotopes have not been measured in the SPGs to so great an extent as to merit a comparison between Archean and Proterozoic samples [although see Nabelek et al. (1992b) for $\mathrm{H}$ isotopes of the Harney Peak granite].

\section{Oxygen isotopes Background}

Studies of oxygen isotopes in igneous and detrital zircon demonstrate that zircon $\delta^{18} \mathrm{O}$ values in the Archean are mostly between 5 and $7 \%$, suggesting crystallization from dominantly mantle-derived melts, whereas zircon $\delta^{18} \mathrm{O}$ shifts abruptly in the Proterozoic to higher and more variable values (up to $10 \%$ ) (Valley, 2003; Valley et al., 2005; Spencer et al., 2014, 2017; Payne et al., 2015; Fig. 8). Possible causes for the shift in $\delta^{18} \mathrm{O}_{\text {zircon }}$ values may be related to several, nonmutually exclusive factors (see discussion by Valley et al., 2005) including the following: (1) the onset or acceleration of subduction at the end of the Archean, which would enhance the recycling of sediments into the source regions of magmas; (2) the quantity and composition of sediments available for recycling owing to the emergence of a subaerial, evolved crust in the Proterozoic (Spencer et al., 2014); (3) differences in weathering across the GOE, giving rise to higher- $\delta{ }^{18} \mathrm{O}$
Proterozoic sediments that were ultimately assimilated into magmas (Bindeman et al., 2016; Spencer et al., 2019). Support for the latter two causes comes from what is known about the ancient sedimentary record. Archean sediments are characterized by immature, subaqueous volcaniclastic material and shales with low $\delta^{18} \mathrm{O}$ values (Ronov, 1964; Longstaffe \& Schwarcz, 1977; Shieh \& Schwarcz, 1978; Lowe, 1994; Veizer \& Mackenzie, 2003; Bindeman et al., 2016; Fig. 8). In contrast, Proterozoic sedimentary sequences mark the onset of subaerial weathering, characterized by high$\delta^{18} \mathrm{O}$, mature sediments such as clays, and chemical sediments (e.g. carbonates and evaporates) (Ronov, 1964; Grotzinger \& James, 2000; Veizer \& Mackenzie, 2003; Campbell \& Davies, 2017). In addition, the rise of atmospheric oxygen diversified the number of clay minerals (e.g. $\mathrm{Fe}^{3+}$-bearing smectites) through oxidative weathering of subaerial continental crust (Hazen et al., 2013).

Testing whether the secular change in $\delta^{18} \mathrm{O}_{\text {zircon }}$ values was primarily due to a change in sediment composition or volume or in tectonic regime is difficult using zircon from a broadly sampled igneous record. First, igneous rocks often have a complicated origin and may have both mantle and crustal source components. Second, detrital zircons (which are the primary dataset for more recent studies demonstrating a secular trend in $\delta^{18} \mathrm{O}_{\text {zircon }}$ values) have no petrological context to understand their origin (see Spencer et al., 2019). As SPGs are derived entirely from the partial melting of metasedimentary rocks, they therefore should preserve a pure sedimentary signal in their oxygen isotope values. If a stepwise change is observed, this suggests that the increase in $\delta^{18} \mathrm{O}$ values of igneous zircon at c. 2.3$2.4 \mathrm{Ga}$ was due, at least in part, to the increasing $\delta^{18} \mathrm{O}$ of sediments. On the other hand, if there is no shift across the Archaean-Proterozoic transition in the $\delta^{18} \mathrm{O}$ values of the SPGs, then sedimentary rocks must have been incorporated into magmas in more abundant amounts via enhanced crustal recycling (through the formation of larger volumes of sediments or enhanced subduction). In addition, mineral $\delta^{18} \mathrm{O}$ values of SPGs are a complementary, and in some cases, more robust record than the sedimentary archive as the $\delta^{18} \mathrm{O}$ values of some minerals (such as zircon) are more resistant to subsequent alteration than whole-rock values (Valley, 2003). Although diagenesis and metamorphism (prerequisites prior to partial melting) certainly will affect the $\delta^{18} \mathrm{O}$ values of the source rocks for the SPGs, SPGs should still faithfully record relative variations in sedimentary $\delta^{18} \mathrm{O}$ values as these processes should affect the $\delta^{18} \mathrm{O}$ values of Archean and Proterozoic sedimentary rocks equally.

\section{Oxygen isotopes in Archean and Proterozoic SPGs}

Archean SPGs with previously measured $\delta^{18} \mathrm{O}$ values (of both whole-rocks and minerals) include the 
Table 3: Archean and Proterozoic SPG oxygen isotope literature data summary

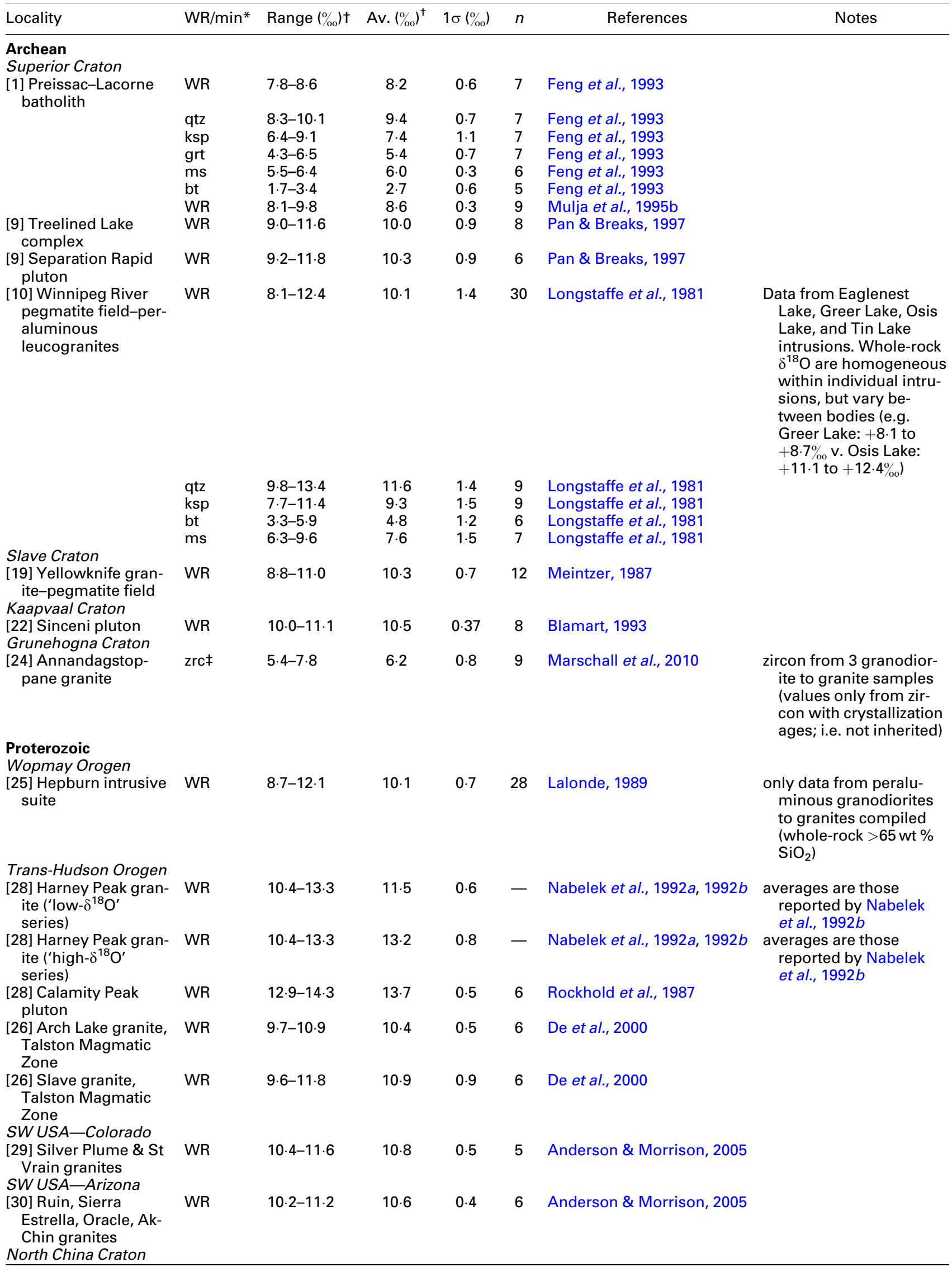


Table 3: Continued

\begin{tabular}{|c|c|c|c|c|c|c|c|}
\hline Locality & $\mathrm{WR} / \mathrm{min}^{*}$ & Range $(\%) \dagger$ & Av. $(\%)^{\dagger}$ & $1 \sigma(\%)$ & $n$ & References & Notes \\
\hline $\begin{array}{l}\text { [33] Helanshan } \\
\text { complex }\end{array}$ & zrc $¥$ & $7 \cdot 3-10 \cdot 6$ & $9 \cdot 4$ & 1 & 37 & Dan et al., 2014 & $\begin{array}{l}\text { zircon data from two dif- } \\
\text { ferent granite samples }\end{array}$ \\
\hline \multirow[t]{2}{*}{$\begin{array}{l}\text { [32] Liangcheng } \\
\text { granites }\end{array}$} & zrc $\ddagger$ & $9 \cdot 2-11 \cdot 6$ & $10 \cdot 5$ & 0.5 & 143 & Wang et al., 2018 & $\begin{array}{l}5 \text { different samples of } \\
\text { grt-bt to grt-opx gran- } \\
\text { itoids; only values from } \\
\text { zircon with 'magmatic' } \\
\text { textures included }\end{array}$ \\
\hline & $\operatorname{zrc} \ddagger$ & $7 \cdot 2-9 \cdot 1$ & $8 \cdot 2$ & 0.5 & 45 & Wang et al., 2017 & $\begin{array}{l}3 \text { different samples of } \\
\text { 'meta-leucogranites' } \\
\text { (grt-, bt-, and sil-bear- } \\
\text { ing); only values from } \\
\text { zircon with 'magmatic' } \\
\text { textures included }\end{array}$ \\
\hline
\end{tabular}

Locality number in brackets is locality number in Table 1.

*Indicates whether reported values are for whole-rock (WR) or mineral separates. qtz, quartz; ksp, K-feldspar; grt, garnet; ms, muscovite; bt, biotite; zrc, zircon.

${ }^{\dagger} \mathrm{O}$ isotope values are reported in per mil notation relative to the Vienna Standard Mean Ocean Water (VSMOW).

${ }^{\ddagger}$ Measured in situ via secondary ion mass spectrometry.

Annandagstoppane granite of Antarctica $(\sim 3.1 \mathrm{Ga}$; Marschall et al., 2010), the Preissac-Lamotte-LacorneMoly Hill granites of Quebec ( 2.6 Ga; Feng et al., 1993; Mulja et al., 1995b), the Treelined Lake complex (Pan \& Breaks, 1997); the Yellowknife granite-pegmatite field (Prosperous granite, Meintzer, 1987), the Winnipeg River pegmatite field (Longstaffe et al., 1981), and the Sinceni pluton of the Kaapvaal Craton (Blamart, 1993). Paleoproterozoic SPGs with previously measured $\delta^{18} \mathrm{O}$ values are the Harney Peak granite and satellite intrusions (Walker et al., 1986; Rockhold et al., 1987; Shearer et al., 1987; Nabelek et al., 1992b), the Helanshan Complex (Dan et al., 2014) and Liangcheng granites (Wang et al., 2017, 2018) of the North China Craton, and the Taltson Magmatic Zone of Saskatchewan (De et al., 2000). A summary of oxygen isotope data from the literature is provided in Table 3.

Average whole-rock, zircon, and quartz $\delta^{18} \mathrm{O}$ values from SPGs all increase from the Archean to the Paleoproterozoic (Fig. 9a-f). Among mineral phases in high-silica rocks, zircon is generally taken as the most reliable recorder of magmatic $\delta^{18} \mathrm{O}$ values owing to its slow $O$ self-diffusivity and robustness to alteration (Valley, 2003; Bindeman et al., 2018). [Garnet, although considered a phase often resistant to weathering, is not always present in high-silica rocks, with SPGs being a notable exception (King \& Valley, 2001).] Zircon $\delta^{18} O$ values in Archean SPGs are limited in number and derive solely from the Annandagstoppane granite (Marschall et al., 2010) with a mean value of $6.1 \pm 1.6 \%$ $\left(2 \sigma_{\mathrm{SD}}, n=10\right.$; Fig. 9c). Available zircon $\delta^{18} \mathrm{O}$ data for Paleoproterozoic SPGs exist only for the Helanshan Complex (Dan et al., 2014) and the Liangcheng granites (Wang et al., 2017, 2018) of the North China Craton and yield significantly higher average values of $9.9 \pm 2.2 \%$ $\left(2 \sigma_{\mathrm{SD}}, n=225\right)$ (Fig. 9d). However, as the present zircon $\delta^{18} \mathrm{O}$ data are limited [from one Archean locality (with 10 analyses) and two Paleoproterozoic localities], we discuss whole-rock and quartz $\delta^{18} \mathrm{O}$ values as well, even though these materials are known to be more susceptible to alteration of primary magmatic $\delta^{18} \mathrm{O}$ values by weathering (for whole-rock samples) or sub-solidus reequilibration (e.g. for quartz; Giletti \& Yund, 1984; Eiler et al., 1992). The averages of all available quartz $\delta^{18} \mathrm{O}$ values from Archean and Proterozoic SPG localities are $10.6 \pm 3.2 \% \quad\left(2 \sigma_{\mathrm{SD}}, \quad n=16\right) \quad$ and $13.4 \pm 2.5 \% \quad\left(2 \sigma_{\mathrm{SD}}\right.$ $n=61$ ), respectively, whereas whole-rock $\delta^{18} \mathrm{O}$ values are $9.8 \pm 2.5 \%$ and $11.0 \pm 3.3 \%$ (Fig. $9 a, b$, e and f; Table 3). The average zircon, quartz, and whole-rock $\delta^{18} \mathrm{O}$ values from the Archean and Proterozoic are statistically distinguishable with $t$-test $p$ values of $<0.001$.

Magmatic $\delta^{18} \mathrm{O}$ values can increase through differentiation and concomitant $\mathrm{SiO}_{2}$ enrichment in the melt (Eiler, 2001; Bindeman et al., 2004; Bucholz et al., 2017). However, the difference in whole-rock $\delta^{18} \mathrm{O}$ values is not simply a function of an increase in whole-rock $\mathrm{SiO}_{2}$ contents. Indeed, in the oxygen isotope compilation, the Archean samples skew to higher $\mathrm{SiO}_{2}$ contents than the Proterozoic samples while maintaining distinctly lower $\delta^{18} \mathrm{O}$ values (Fig. 9g). Unfortunately, for most studies included in the compilation, mineral pairs were not measured, rendering implementation of oxygen isotope thermometry impossible. An exception to this is the study of Nabelek et al. (1992b) in which the authors comprehensively measured quartz, feldspar, garnet, muscovite, biotite, and tourmaline $\delta^{18} \mathrm{O}$ values from over 50 samples from the Harney Peak granite and associated pegmatites. Calculated oxygen isotope equilibration temperatures are widely variable (408$848^{\circ} \mathrm{C}$, excluding feldspar-quartz pairs, which yielded a lower range of $300-550^{\circ} \mathrm{C}$ ), suggesting that in many samples significant subsolidus re-equilibration of oxygen isotopes in quartz and other minerals occurred. Further such detailed studies involving mineral pair oxygen isotope measurements (e.g. zircon and garnet) will need to be undertaken to verify which values are representative of magmatic $\delta^{18} \mathrm{O}$ values. Although the SPG data summarized in Figs 8 and 9 come from a 

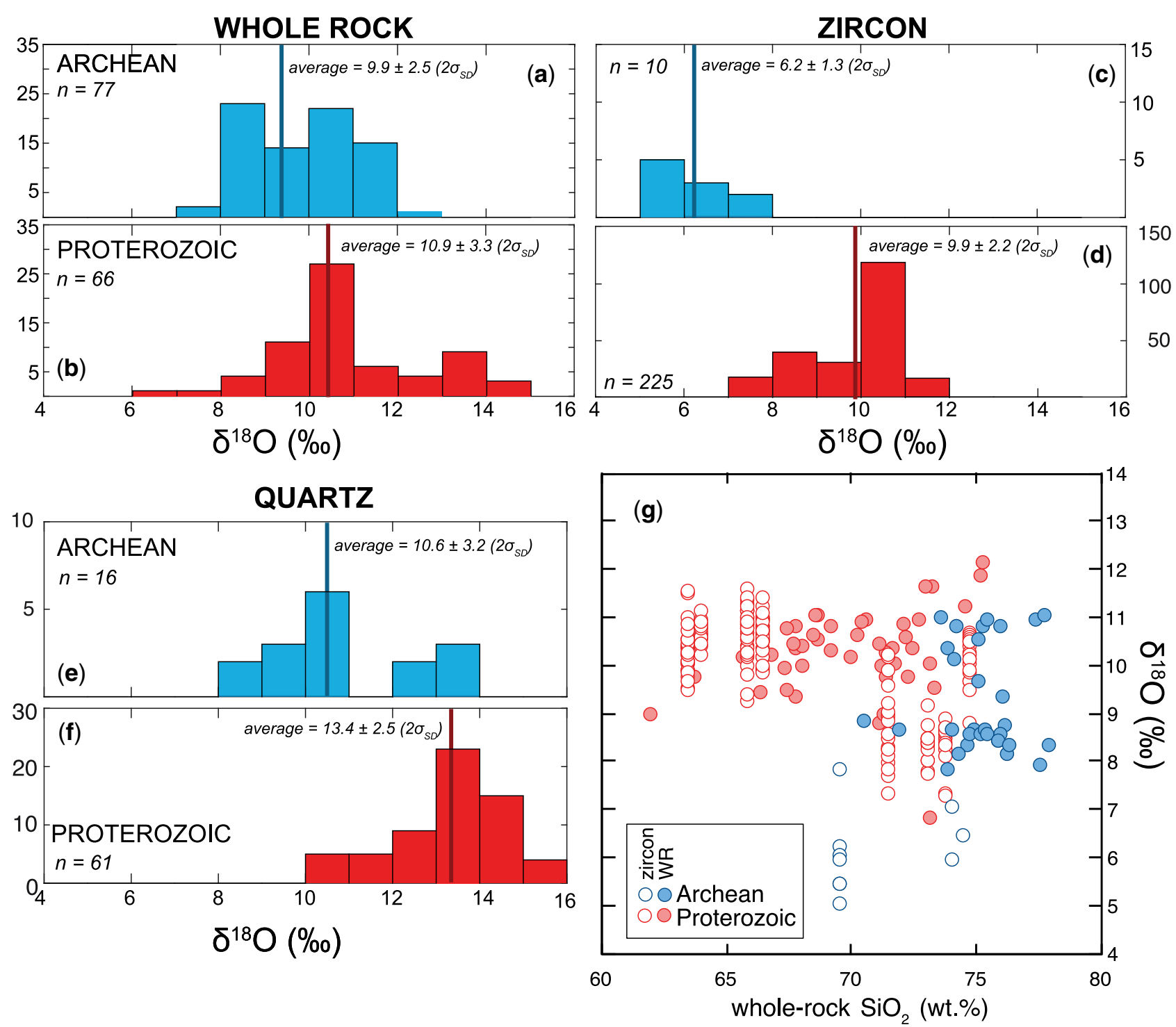

Fig. 9. Oxygen isotope ratios [expressed as $\delta^{18} \mathrm{O}(\%)$ ] of Archean and Proterozoic SPGs. Histograms of whole-rock (a, b), zircon (c, d), and quartz $(\mathrm{e}, \mathrm{f}) \delta^{18} \mathrm{O}$ values. $(\mathrm{g})$ Whole-rock and zircon $\delta^{18} \mathrm{O}$ values versus whole-rock $\mathrm{SiO}_{2}$ for samples where whole-rock major element analyses were available. Summary of data and data sources are given in Table 3.

relatively small set of data, it is nevertheless important to note that the $\delta^{18} \mathrm{O}$ data from the Archean to Proterozoic SPGs come from four continents (Antarctica, North America, Europe, Asia) and are consistent between zircon, quartz, and whole-rock values. The shift in $\delta^{18} \mathrm{O}$ mineral and whole-rock values is consistent with the hypothesis that sedimentary $\delta^{18} \mathrm{O}$ values underwent a dramatic increase across the ArcheanProterozoic transition, potentially owing to the rise of new styles of weathering of subaerial landmasses in an oxygenated atmosphere.

\section{PERSPECTIVES}

The motivation and premise for this review paper is that SPGs may be able to shed light on how variations at the surface of the Earth and in sedimentary rock compositions across the Archean-Proterozoic transition may have been imprinted on the igneous rock record. In particular, the Archean-Proterozoic transition coincided with both the rise of subaerial weathering and the Great Oxidation Event, both of which profoundly influenced the chemistry and lithologies of sedimentary rocks. Further, SPGs may provide complementary insight into the evolution of sediments across Earth's history as they can mitigate some of the issues associated with poor preservation of the sedimentary rock record. We briefly summarize our key findings.

1. No systematic variations between Archean and Proterozoic SPGs in terms of mineral assemblages are observed. Because of their strongly peraluminous nature, all are characterized by biotite and/or 
muscovite, sometimes with another peraluminous indicator mineral such as garnet, cordierite, or tourmaline. Biotite compositions and the presence of magnetite in some Proterozoic SPGs, however, indicate that Archean SPGs on average crystallized from melts characterized by lower oxygen fugacity values, which may reflect derivation from sedimentary source rocks with more reduced bulk redox states prior to the Great Oxidation Event.

2. Whole-rock chemistry indicators of temperatures of melting and source lithology (e.g. greywackes versus pelites) imply that although specific SPGs localities are characterized by coherent patterns (e.g. high-temperature melting of greywackes), there is no systematic difference between Archean and Proterozoic SPGs as a whole. This in turn suggests that the generation of SPGs on either side of the Great Oxidation Event was not characterized by distinct temperatures of melting or maturity of sedimentary source rocks. These conclusions are based on a relatively limited dataset predominantly defined by SPGs that appear to have been derived from both clay-rich and clay-poor source regions.

3. Although interpretation of radiogenic isotopes in SPGs (e.g. Sr or Nd) is complicated owing to disequilibrium melting of accessory phases such as monazite, the oxygen isotope composition of SPGs should reflect variations in source rock oxygen isotope ratios. Whole-rock, quartz, and zircon $\delta^{18} \mathrm{O}$ values, although currently limited in number and geographical locality, are on average higher in Proterozoic SPGs as compared with Archean SPGs. This shift in $\delta^{18} \mathrm{O}$ values is consistent with the hypothesis that sedimentary $\delta^{18} \mathrm{O}$ values increased across the Archean-Proterozoic transition as a result of the onset of oxidative weathering of subaerial landmasses.

Above, we discussed what is known about Archean and Paleoproterozoic SPG localities in terms of petrology and chemistry. However, there exist large gaps in our knowledge of these rocks and there is abundant future work to be done on them. Below we outline several fruitful areas for research and potential avenues forward.

\section{Detailed field studies, petrology, and geochronology}

In this review, we have attempted to catalog and describe all the localities of Archean and Paleo- to Mesoproterozoic SPGs in the literature. The SPGs from the localities listed in Table 1 have been studied to greater or lesser degrees. For some, a combination of careful field mapping and sampling [e.g. the Ghost Lake batholith (Breaks \& Moore, 1992) or the Harney Peak granite (Nabelek, 1999, and references therein)] have allowed for a detailed understanding of their petrogenesis and relationship to broader tectonic events. Many others require more detailed studies to understand their source rock characteristics and ages, crystallization ages through modern geochronological techniques, and crystallization conditions as inferred from quantitative thermobarometry. Many of the granite localities in Table 1 do not have robust age constraints. For example, many localities from the Superior Craton are only known to be Neoarchean in age (e.g. Allison Lake batholith) and others, such as the Silver Plume and St Vrain granites, have ages based on $\mathrm{Rb}-\mathrm{Sr}$ whole-rock and mineral isochrons (Peterman et al., 1968). Precise and accurate age constraints are required to explore the temporal evolution of isotope systems in these granites. To obtain crystallization ages zircon rims should be analyzed, as SPGs are often characterized by zircon with inherited cores owing to partial dissolution of zircon during partial melting (Miller et al., 2003).

A critical objective of any future studies should be to constrain the depositional age of the sedimentary source material. As constraining crustal residence ages through radiogenic isotope systems is complicated in SPGs, analyzing inherited cores of zircon in the granites will provide provenance and maximum depositional age information, analogous to the detrital zircon technique in sediments (Gehrels, 2014). This will allow correlation of geochemical signals in the SPGs not only with the age of crystallization, but also with the age of source rock deposition and will be particularly important for Proterozoic sediments to screen for SPGs that may have been derived from Archean sediments.

\section{Mineral chemistry}

Detailed studies of individual localities and their mineral chemistry can yield information concerning intensive variables during granite formation. For example, in a study of Archean and Proterozoic SPGs from North America, Bucholz et al. (2018) used biotite and wholerock $\mathrm{Fe}^{\mathrm{T}} / \mathrm{Mg}$ ratios to demonstrate that on average the Archean SPGs crystallized at higher oxygen fugacity values than the Proterozoic SPGs. They related this shift in $f_{\mathrm{O}_{2}}$ values to the more oxidized sedimentary sources of the Proterozoic SPGs owing to deposition under oxidative weathering conditions after the GOE. The protocol developed for constraining the $f_{\mathrm{O}_{2}}$ during crystallization for SPGs in that paper could be applied to a wider sample suite from different continents and a wider temporal range. In addition, although based on a limited dataset, $\mathrm{Fe}^{3+} / \mathrm{Fe}^{\top}$ ratios of biotites in SPGs are generally lower (0.04-0.09) as compared with those of Itype granites (generally $>0.1$ ) (De Albuquerque, 1973; Ishihara, 1977; Lalonde \& Bernard, 1993). Measurement of $\mathrm{Fe}^{3+} / \mathrm{Fe}^{\top}$ ratios in biotite in Archean and Proterozoic SPGs could be another fruitful way forward, to constrain relative $f_{\mathrm{O}_{2}}$ values.

In garnet-bearing SPGs, detailed studies of garnet textures and compositions (e.g. Taylor \& Stevens, 2010), as well as garnet-biotite thermometry (e.g. Holdaway, 2000), can yield information on garnet formation mechanisms (e.g. through peritectic reactions) 
and crystallization conditions. This information, in turn, will inform how bulk-rock compositions should be interpreted (as melt or a mixture of melt + restite) and SPG formation mechanisms (Stevens et al., 2007).

\section{Oxygen isotopes}

As reviewed above, there is a general paucity of oxygen isotope data on SPGs from the Archean and Proterozoic and, in particular, single mineral oxygen isotope data. Obtaining oxygen isotope ratios for minerals considered relatively robust to subsolidus diffusive oxygen isotope re-equilibration (e.g. zircon and garnet) would inform the long-standing problem concerning secular variation of oxygen isotope ratios in both sedimentary and igneous rocks (see previous section on oxygen isotopes). Obtaining data for mineral pairs from individual samples will be crucial to assess the temperatures at which oxygen isotope equilibrium was achieved and whether the minerals faithfully recording magmatic values (in contrast to sub-solidus conditions).

\section{Sulfur isotopes}

Although our discussion of stable isotopes has concerned only oxygen isotopes, sulfur isotope studies of Archean and Proterozoic SPGs would yield interesting information on several fronts. First, sulfur in the sedimentary record primarily occurs either in its oxidized form as sulfate or its reduced form as sulfide (Canfield, 2001). Sulfate has higher ${ }^{34} \mathrm{~S} /{ }^{32} \mathrm{~S}$ ratios as compared with coexisting sulfide at equilibrium (i.e. higher $\delta^{34} \mathrm{~S}$ values). Further, during reduction of sulfate ions by anaerobic bacteria, the remaining sulfate is further enriched in ${ }^{34} \mathrm{~S}$. The sedimentary sources from which Archean SPGs were derived were probably dominated by sulfide-bearing metasedimentary rocks because of the relatively low $f_{\mathrm{O}_{2}}$ values inferred in their genesis (Bucholz et al., 2018). In contrast, Proterozoic SPGs may have been derived from a significantly more oxidized source region, potentially owing to the incorporation of sulfate deposits, which became abundant only in the Proterozoic. If sulfate is the cause of the increase in $f_{\mathrm{O}_{2}}$ values of SPGs in the Proterozoic, rocks that preserve evidence for elevated $f_{\mathrm{O}_{2}}$ values during crystallization may also have elevated $\delta^{34} S$ values. For example, there is some evidence that sulfur isotopes in igneous rocks may mirror the bulk sulfur oxidation state of their source region, with more reduced 'ilmeniteseries' granitoids and more oxidized 'magnetite-series' granitoids from Japan and the Sierra Nevada batholith having lower $\left(0\right.$ to $-10 \%$ ) and higher $\left(+1\right.$ to $9 \%$ ) $\delta^{34} \mathrm{~S}$ values, respectively (Sasaki \& Ishihara, 1979; Ishihara \& Sasaki, 1989).

Second, Archean sulfide and (less-abundant) sulfate minerals display mass-independent fractionations (MIF) among the four stable sulfur isotopes, providing evidence for an anoxic atmosphere at that time (e.g. Farquhar et al., 2000; Johnston, 2011; Paris et al., 2014). Examining MIF signatures in sulfur-bearing minerals has been classically used in the study of Archean sedimentary rocks, but has been extended to igneous rocks through analysis of sulfide inclusions in ocean island basalts (Cabral et al., 2013; Delavault et al., 2016) and diamonds (Farquhar et al., 2002; Thomassot et al., 2009; Smit et al., 2019). For example, small S-MIF $(<1 \%)$ have been observed in sulfides from ocean island basalts from Mangaia and Pitcairn and have been interpreted as indicating a deep, long-lived subducted Archean component in their mantle source regions (Cabral et al., 2013; Delavault et al., 2016). However, it is not well understood how sulfur isotopes are transferred to the igneous record, as sulfur isotopes in igneous rocks (and particularly ${ }^{33} \mathrm{~S}$ or ${ }^{36} \mathrm{~S}$ ) are generally not analyzed and have not received much attention. A careful study of Archean SPGs and rocks representative of their metasedimentary source rocks could help shed light on the fundamentals of sulfur isotope transfer from the sedimentary to the igneous rock record.

\section{Other stable isotopes}

Numerous other stable isotope systems in sedimentary rocks have been observed to undergo radical changes across the GOE (e.g. Fe, Rouxel et al., 2005; Mo, Planavsky et al., 2014; Cu, Fru et al., 2016; U, Kendall et al., 2013). These shifts in isotope ratios are hypothesized to have occurred as a result of changing redox conditions during sediment transport and/or deposition. An outstanding question is whether these shifts are also preserved in Archean versus Proterozoic SPGs. Each of these systems will need to be studied in detail to determine how metamorphism and partial melting affected the isotopes of the metasedimentary source rock and ultimately strongly peraluminous magmas derived from such source rocks.

For all these time-variant isotope systems, Archean and Proterozoic SPGs are uniquely situated to offer a complementary archive to the existing sedimentary record. First, SPGs have the unique capability to homogenize large packages of sedimentary rocks, giving an 'average' composition throughout this critical time in Earth history. This helps to eliminate some of the sampling and preservation bias inherent in the sedimentary record. Second, the source rock sediments for SPG formation are often those deposited on continental slopes or in the deep ocean, which represent different lithofacies from the cratonal sequences that are traditionally analyzed in sedimentary studies.

\section{ACKNOWLEDGEMENTS}

During the preparation of this paper conversations about the details of local Archean and Proterozoic geology were conducted with numerous people, including F. Breaks, Y. Pan, P. Weiblen, T. Boerboom, C. Frost, R. Frost, D. Bagdonas, H. Marschall, P. Nabelek, I. Annesley, and L. Anderson. We thank these people for sharing their knowledge of these unique rocks. S. Newall is thanked for assistance with sample 
preparation for whole-rock XRF analyses. C. Frost and I. Bindeman provided thoughtful and constructive reviews that improved this paper. We also thank M. Holness for the suggestion to write such a review and her infinite patience while we put this paper together.

\section{SUPPLEMENTARY DATA}

Supplementary data for this paper are available at Journal of Petrology online.

\section{REFERENCES}

Abdel-Rahman, A. F. M. (1994). Nature of biotites from alkaline, calc-alkaline, and peraluminous magmas. Journal of Petrology 35, 525-541.

Ague, J. J. \& Brimhall, G. H. (1988). Regional variations in bulk chemistry, mineralogy, and the compositions of mafic and accessory minerals in the batholiths of California. Geological Society of America Bulletin 100, 891-911.

Allan, B. D. \& Clarke, D. B. (1981). Occurrence and origin of garnets in the South Mountain Batholith, Nova Scotia. Canadian Mineralogist 19, 19-24.

Almeida, M. E., Macambira, M. J. \& Oliveira, E. C. (2007). Geochemistry and zircon geochronology of the I-type high-K calc-alkaline and S-type granitoid rocks from southeastern Roraima, Brazil: Orosirian collisional magmatism evidence (1.97-1.96 Ga) in central portion of Guyana Shield. Precambrian Research 155, 69-97.

Almeida, M. E., Macambira, M. J. \& Valente, S. D. C. (2008). New geological and single-zircon $\mathrm{Pb}$ evaporation data from the central Guyana domain, southeastern Roraima, Brazil: tectonic implications for the central region of the Guyana shield. Journal of South American Earth Sciences 26, 318-328.

Althoff, F., Barbey, P. \& Boullier, A. M. (2000). 2.8-3.0 Ga plutonism and deformation in the SE Amazonian craton: the Archaean granitoids of Marajoara (Carajás Mineral Province, Brazil). Precambrian Research 104, 187-206.

Anderson, J. L. \& Bender, E. E. (1989). Nature and origin of Proterozoic A-type granitic magmatism in the southwestern United States of America. Lithos 23, 19-52.

Anderson, J. L. \& Cullers, R. L. (1999). Paleo- and Mesoproterozoic granite plutonism of Colorado and Wyoming. Rocky Mountain Geology 34, 149-164.

Anderson, J. L. \& Morrison, J. (1992). The role of anorogenic granites in the Proterozoic crustal development of North America. In: Condie, K. C. V. (ed.) Developments in Precambrian Geology, Proterozoic Crustal Evolution. Amsterdam: Elsevier, 10, pp. 263-299.

Anderson, J. L. \& Morrison, J. (2005). Ilmenite, magnetite, and peraluminous Mesoproterozoic anorogenic granites of Laurentia and Baltica. Lithos 80, 45-60.

Anderson, J. L. \& Thomas, W. M. (1985). Proterozoic anorogenic two-mica granites: silver plume and St. Vrain batholiths of Colorado. Geology 13, 177-180.

Annesley, I. R., Madore, C. \& Krogh, T. E. (1997). U-Pb geochronology of peraluminous pegmatites from the Wollaston Lake area, northern Saskatchewan. Geological Association of Canada-Mineralogical Association of Canada, Program with Abstracts 22, A-4.

Annesley, I. R., Madore, C. \& Portella, P. (2005). Geology and thermotectonic evolution of the western margin of the Trans-Hudson Orogen: evidence from the eastern sub-Athabasca basement, Saskatchewan. Canadian Journal of Earth Sciences 42, 573-597.
Ansdell, K. M. (2005). Tectonic evolution of the Manitoba-Saskatchewan segment of the Paleoproterozoic Trans-Hudson orogen, Canada. Canadian Journal of Earth Sciences 42, 741-759.

Arndt, N. (1999). Why was flood volcanism on submerged continental platforms so common in the Precambrian? Precambrian Research 97, 155-164.

Arndt, N. T., Coltice, N., Helmstaedt, H. \& Gregoire, M. (2009). Origin of Archean subcontinental lithospheric mantle: some petrological constraints. Lithos 109, 61-71.

Ayres, M. \& Harris, N. (1997). REE fractionation and Nd-isotope disequilibrium during crustal anatexis: constraints from Himalayan leucogranites. Chemical Geology 139, 249-269.

Bagdonas, D. A. (2014). Petrogenesis of the Neoarchean Wyoming batholith, Central Wyoming. MSc thesis, University of Wyoming, Laramie, WY.

Bagdonas, D. A., Frost, C. D. \& Fanning, C. M. (2016). The origin of extensive Neoarchean high-silica batholiths and the nature of intrusive complements to silicic ignimbrites: insights from the Wyoming batholith, USA. American Mineralogist 101, 1332-1347.

Baratoux, L., Metelka, V., Naba, S., Jessell, M. W., Grégoire, M. \& Ganne, J. (2011). Juvenile Paleoproterozoic crust evolution during the Eburnean orogeny $(2 \cdot 2-2 \cdot 0 \mathrm{Ga})$, western Burkina Faso. Precambrian Research 191, 18-45.

Barbero, L., Villaseca, C., Rogers, G. \& Brown, P. E. (1995). Geochemical and isotopic disequilibrium in crustal melting: an insight from the anatectic granitoids from Toledo, Spain. Journal of Geophysical Research: Solid Earth 100, 15745-15765.

Barbosa, J. S. F. \& Sabaté, P. (2004). Archean and Paleoproterozoic crust of the São Francisco craton, Bahia, Brazil: geodynamic features. Precambrian Research 133, 1-27.

Barker, F. (1979). Trondhjemite: definition, environment and hypotheses of origin. In: Barker, F. (ed.) Trondhjemites, Dacites and Related Rocks. Amsterdam: Elsevier, pp. 1-11.

Barton, J. M., Klemd, R., Allsopp, H. L., Auret, S. H. \& Copperthwaite, Y. E. (1987). The geology and geochronology of the Annandagstoppane granite, Western Dronning Maud Land, Antarctica. Contributions to Mineralogy and Petrology 97, 488-496.

Bayley, R. W., Proctor, P. D. \& Condie, K. C. (1973). Geology of the South Pass area, Fremont County, Wyoming. US Geological Survey, Professional Papers 793.

Bea, F., Fershtater, G. \& Corretgé, L. G. (1992). The geochemistry of phosphorus in granite rocks and the effect of aluminium. Lithos 29, 43-56.

Bekker, A., Karhu, J. A., Eriksson, K. A. \& Kaufman, A. J. (2003). Chemostratigraphy of Paleoproterozoic carbonate successions of the Wyoming Craton: tectonic forcing of biogeochemical change? Precambrian Research 120, 279-325.

Bekker, A., Holland, H. D., Wang, P. L., Rumble, D., III, Stein, H. J., Hannah, J. L., Coetzee, L. L. \& Beukes, N. J. (2004). Dating the rise of atmospheric oxygen. Nature 427, 117.

Bergman, S., Högdahl, K., Nironen, M., Ogenhall, E., Sjöström, H., Lundqvist, L. \& Lahtinen, R. (2008). Timing of Palaeoproterozoic intra-orogenic sedimentation in the central Fennoscandian Shield; evidence from detrital zircon in metasandstone. Precambrian Research 161, 231-249.

Berman, R. G. \& Bostock, H. H. (1997). Metamorphism in the northern Taltson magmatic zone. Northwest Territories. Canadian Mineralogist 35, 1069-1091.

Bindeman, I. N., Ponomareva, V. V., Bailey, J. C. \& Valley, J. W. (2004). Volcanic arc of Kamchatka: a province with high- $\delta^{18} \mathrm{O}$ magma sources and large-scale ${ }^{18} \mathrm{O} /{ }^{16} \mathrm{O}$ depletion of the upper crust. Geochimica et Cosmochimica Acta 68, 841-865. 
Bindeman, I. N., Bekker, A. \& Zakharov, D. O. (2016). Oxygen isotope perspective on crustal evolution on early Earth: A record of Precambrian shales with emphasis on Paleoproterozoic glaciations and Great Oxygenation Event. Earth and Planetary Science Letters 437, 101-113.

Bindeman, I., Schmitt, A., Lundstrom, C. \& Hervig, R. (2018). Stability of zircon and its isotopic ratios in high-temperature fluids: long-term (4 months) isotope exchange experiment at $850^{\circ} \mathrm{C}$ and $50 \mathrm{MPa}$. Frontiers in Earth Science 6

Blamart, D., Trumbull, R. B. \& Chaussidou, M. (1993). Oxygen and boron isotopic composition of the Archaean Sinceni pluton: implications for the occurrence of S-type granites in Swaziland. Abstracts, 16th Colloquium of African Geology, Ezuliwini, Swaziland, pp. 29-31.

Bleeker, W. (2003). The late Archean record: a puzzle in ca. 35 pieces. Lithos 71, 99-134.

Blevin, P. L. \& Chappell, B. W. (1992). The role of magma sources, oxidation states and fractionation in determining the granite metallogeny of eastern Australia. Earth and Environmental Science Transactions of the Royal Society of Edinburgh 83, 305-316.

Block, S., Moyen, J. F., Zeh, A., Poujol, M., Jaguin, J. \& Paquette, J. L. (2013). The Murchison greenstone belt, South Africa: accreted slivers with contrasting metamorphic conditions. Precambrian Research 227, 77-98.

Blockley, J. G. (1980). The Tin Deposits of Western Australia, with Special Reference to the Associated Granites. Geological Survey of Western Australia, Mineral Resources Bulletin 12, $184 \mathrm{pp}$.

Boehnke, P., Watson, E. B., Trail, D., Harrison, T. M. \& Schmitt, A. K. (2013). Zircon saturation re-revisited. Chemical Geology 351, 324-334.

Boerboom, T. J. \& Zartman, R. E. (1993). Geology, geochemistry, and geochronology of the central Giants Range batholith, northeastern Minnesota. Canadian Journal of Earth Sciences 30, 2510-2522.

Boher, M., Abouchami, W., Michard, A., Albarède, F. \& Arndt, N. T. (1992). Crustal growth in West Africa at 2.1 Ga. Journal of Geophysical Research 97, 345-369.

Bostock, H. H. \& Loveridge, W. D. (1988). Geochronology of the Taltson magmatic zone, and its eastern cratonic margin, District of Mackenzie. Radiogenic age and isotopic studies: report 2. Geological Survey of Canada, Paper 88-2, 59-65.

Bostock, H. H. \& van Breemen, O. (1994). Ages of detrital and metamorphic zircons and monazites from a pre-Taltson magmatic zone basin at the western margin of the Rae province. Canadian Journal of Earth Sciences 31, 1353-1364.

Bostock, H. H., van Breemen, O. \& Loveridge, W. D. (1987). Proterozoic geochronology in the Taltson magmatic zone, N.W.T. Radiogenic age and isotopic studies: report 1. Geological Survey of Canada, Paper 87-2, 73-80.

Bostock, H. H., van Breemen, O. \& Loveridge, W. D. (1991). Further geochronology of plutonic rocks in northern Taltson magmatic Zone, District of Mackenzie, NWT. Radiogenic age and isotopic studies. Report 4. Geological Survey of Canada, Paper 67-78, 90-2.

Bourne, J. \& Danis, D. (1987). A proposed model for the formation of reversely zoned plutons based on a study of the Lacorne Complex, Superior Province, Quebec. Canadian Journal of Earth Sciences 24, 2506-2520.

Breaks, F. W. \& Janes, D. A. (1991). Granite-related mineralization of the Dryden Area, Superior Province of northwestern Ontario. Field Trip B7 Guidebook. Sudbury, ON: Geological Association of Canada, Toronto'91 Organizing Committee, $71 \mathrm{pp}$.

Breaks, F. W. \& Moore, J. M. (1992). The Ghost Lake batholith, Superior Province of northwestern Ontario; a fertile, S-type, peraluminous granite-rare-element pegmatite system. Canadian Mineralogist 30, 835-875.

Breaks, F. W., Selway, J. B. \& Tindle, A. G. (2003). Fertile peraluminous granites and related rare-element mineralization in pegmatites, Superior Province, northwest and northeast Ontario: Operation Treasure Hunt. Ontario Geological Survey, Open File Report 6099.

Breaks, F. W., Selway, J. B. \& Tindle, A. G. (2005). Fertile peraluminous granites and related rare element pegmatites, Superior Province of Ontario. In: Linnen, R. L. \& Samson, I. M. (eds) Rare Element Geochemistry and Mineral Deposits. Geological Association of Canada, Short Course Notes 17, 87-125.

Broska, I., Williams, C. T., Uher, P., Konečný, P. \& Leichmann, J. (2004). The geochemistry of phosphorus in different granite suites of the Western Carpathians, Slovakia: the role of apatite and P-bearing feldspar. Chemical Geology 205, 1-15.

Bucholz, C. E., Jagoutz, O., VanTongeren, J. A., Setera, J. \& Wang, Z. (2017). Oxygen isotope trajectories of crystallizing melts: insights from modeling and the plutonic record. Geochimica et Cosmochimica Acta 207, 154-184.

Bucholz, C. E., Stolper, E. M., Eiler, J. M. \& Breaks, F. W. (2018). A comparison of oxygen fugacities of strongly peraluminous granites across the Archean-Proterozoic boundary. Journal of Petrology 59, 2123-2156.

Cabral, R. A., Jackson, M. G., Rose-Koga, E. F., Koga, K. T., Whitehouse, M. J., Antonelli, M. A., Farquhar, J., Day, J. M. \& Hauri, E. H. (2013). Anomalous sulphur isotopes in plume lavas reveal deep mantle storage of Archaean crust. Nature 496, 490-493.

Campbell, I. H. \& Davies, D. R. (2017). Raising the continental crust. Earth and Planetary Science Letters 460, 112-122.

Canfield, D. E. (2001). Biogeochemistry of sulfur isotopes. In: Valley, J. W. \& Cole, D. R. (eds) Stable Isotope Geochemistry. Mineralogical Society of America and Geochemical Society, Reviews in Mineralogy and Geochemistry 43, 607-636.

Canfield, D. E., Habicht, K. S. \& Thamdrup, B. (2000). The Archean sulfur cycle and the early history of atmospheric oxygen. Science $\mathbf{2 8 8}, 658-661$.

Card, K. D. (1990). A review of the Superior Province of the Canadian Shield, a product of Archean accretion. Precambrian Research 48, 99-156.

Catling, D. C. \& Claire, M. W. (2005). How Earth's atmosphere evolved to an oxic state: a status report. Earth and Planetary Science Letters 237, 1-20.

Černý, P. (1989). Contrasting geochemistry of two pegmatite fields in Manitoba: products of juvenile Aphebian crust and polycyclic Archean evolution. Precambrian Research 45, 215-234.

Černý, P. (1990). Distribution, affiliation and derivation of rare-element granitic pegmatites in the Canadian Shield. Geologische Rundschau 79, 183-226.

Černý, P. (1991a). Fertile granites of Precambrian rare-element pegmatite fields: is geochemistry controlled by tectonic setting or source lithologies? Precambrian Research 51, 429-468.

Černý, P. (1991b). Rare-element granitic pegmatites. Part II: regional to global environments and petrogenesis. Geoscience Canada 18, 68-81.

Černý, P., Trueman, D. L., Ziehlke, D. V., Goad, B. E. \& Paul, B. J. (1981). The Cat Lake-Winnipeg River and the Wekusko Lake Pegmatite Fields, Manitoba. Manitoba Department of Energy and Mines, Mineral Resources Division, Economic Geology Report ER80.

Černý, P., Masau, M., Goad, B. E. \& Ferreira, K. (2005). The Greer Lake leucogranite, Manitoba, and the origin of lepidolite-subtype granitic pegmatites. Lithos 80, 305-321. 
Chacko, T. \& Creaser, R. A. (1995). Hercynite bearing granites and associated metasedimentary enclaves from the Taltson Magmatic Zone, Alberta, Canada: a natural example of high temperature pelite melting. In: Brown, M. \& Piccoli, P. M. (eds) Origin of Granites and Related Rocks, Third Hutton Symposium Abstracts, US Geological Survey, Circular 1129, 32-33.

Chacko, T., Creaser, R. A. \& Poon, D. (1994). Spinel + quartz granites and associated metasedimentary enclaves from the Taltson magmatic zone, Alberta, Canada: a view into the root zone of a high temperature S-type granite batholith. Mineralogical Magazine 8A, 161-162.

Chacko, T., De, S. K., Creaser, R. A. \& Muehlenbachs, K. (2000). Tectonic setting of the Taltson magmatic zone at $1.9-2.0 \mathrm{Ga}$ : a granitoid-based perspective. Canadian Journal of Earth Sciences 37, 1597-1609.

Chamberlain, K. R., Frost, C. D. \& Frost, B. R. (2003). Early Archean to Mesoproterozoic evolution of the Wyoming Province: Archean origins to modern lithospheric architecture. Canadian Journal of Earth Sciences 40, 1357-1374.

Champion, D. C. \& Sheraton, J. W. (1997). Geochemistry and $\mathrm{Nd}$ isotope systematics of Archaean granites of the Eastern Goldfields, Yilgarn Craton, Australia: implications for crustal growth processes. Precambrian Research 83, 109-132.

Champion, D. C. \& Smithies, R. H. (2001). Archaean granites of the Yilgarn and Pilbara Cratons, Western Australia. In: Cassidy, K. F., Dunphy, J. M. \& Van Kranendonk, M. J. (eds) Geoscience Australia 2001, 4, 134-136.

Chandler, F. W. (1988). Diagenesis of sabkha-related, sulphate nodules in the early Proterozoic Gordon Lake formation, Ontario, Canada. Carbonates and Evaporites 3, 75-94.

Chappell, B. W. \& White, A. J. R. (1974). Two contrasting granite types. Pacific Geology 8, 173-174.

Chappell, B. W., White, A. J. R. \& Wyborn, D. (1987). The importance of residual source material (restite) in granite petrogenesis. Journal of Petrology 28, 1111-1138.

Chorlton, L. B. (2007). Generalized geology of the world: bedrock domains and major faults in GIS format: a small-scale world geology map with an extended geological attribute database. Geological Survey of Canada, Open File 5529.

Chough, S. K. (2013). Geology and Sedimentology of the Korean Peninsula. Amsterdam: Elsevier, 348 pp.

Clarke, D. B. (1981). The mineralogy of peraluminous granites; a review. Canadian Mineralogist 19, 3-17.

Clemens, J. D. (1989). The importance of residual source material (restite) in granite petrogenesis: a comment. Journal of Petrology 30, 1313-1316.

Clemens, J. D. \& Vielzeuf, D. (1987). Constraints on melting and magma production in the crust. Earth and Planetary Science Letters 86, 287-306.

Clemens, J. D. \& Wall, V. J. (1988). Controls on the mineralogy of S-type volcanic and plutonic rocks. Lithos 21, 53-66.

Collins, W. J. (1996). Lachlan Fold Belt granitoids: products of three-component mixing. Earth and Environmental Science Transactions of the Royal Society of Edinburgh 87, 171-181.

Condie, K. C. (1989). Geochemical changes in basalts and andesites across the Archean-Proterozoic boundary: identification and significance. Lithos 23, 1-18.

Condie, K. C. (1994). Greenstones through time. In: Condie, K. C. (ed.) Archaean Crustal Evolution, Developments in Precambrian Geology, 11. Amsterdam: Elsevier, pp. 85-120.

Condie, K. C. (1998). Episodic continental growth and supercontinents: a mantle avalanche connection? Earth and Planetary Science Letters 163, 97-108.

Condie, K. C. \& O'Neill, C. (2010). The Archean-Proterozoic boundary: $500 \mathrm{My}$ of tectonic transition in Earth history. American Journal of Science 310, 775-790.
Condie, K. C., Des, M. D. J. \& Abbott, D. (2001). Precambrian superplumes and supercontinents: a record in black shales, carbon isotopes, and paleoclimates. Precambrian Research 106, 22.

Condie, K. C., O'Neill, C. \& Aster, R. C. (2009). Evidence and implications for a widespread magmatic shutdown for $250 \mathrm{My}$ on Earth. Earth and Planetary Science Letters 282, 294-298.

Cook, P. J. \& McElhinny, M. W. (1979). A reevaluation of the spatial and temporal distribution of sedimentary phosphate deposits in the light of plate tectonics. Economic Geology 74, 315-330.

Corrigan, D., Pehrsson, S., Wodicka, N. \& De Kemp, E. (2009). The Palaeoproterozoic Trans-Hudson Orogen: a prototype of modern accretionary processes. In: Murphy, J. B., Keppie, J. D. \& Hynes, A. J. (eds) Ancient Orogens and Modern Analogues. Geological Society, London, Special Publications 327, 457-479.

CPRM (2003). Programa Levantamentos Geológicos Básicos do Brasil. Geologia, Tectônica e Recursos Minerais do Brasil: sistema de informações geográficas-SIG. Rio de Janeiro: CPRM, Mapas Escala 1:2.500.000, 4 CDs ROM [abstract in English].

Cuney, M., Sabaté, P., Vidal, P., Marinho, M. M. \& Conceição, H. (1990). The $2 \mathrm{Ga}$ peraluminous magmatism of the Jacobina-Contendas Mirante Belt (Bahia) Brazil: major and trace-element geochemistry and metallogenic potential. Journal of Volcanology and Geothermal Research 44, 23-141.

Czamanske, G. K. \& Wones, D. R. (1973). Oxidation during magmatic differentiation, Finnmarka complex, Oslo Area, Norway: part 2, the mafic silicates. Journal of Petrology 14, 349-380.

Dan, W., Li, X. H., Wang, Q., Wang, X. C., Liu, Y. \& Wyman, D. A. (2014). Paleoproterozoic S-type granites in the Helanshan complex, Khondalite belt, North China Craton: implications for rapid sediment recycling during slab break-off. Precambrian Research 254, 59-72.

Davis, D. W. (2002). U-Pb geochronology of Archean metasedimentary rocks in the Pontiac and Abitibi subprovinces, Quebec, constraints on timing, provenance and regional tectonics. Precambrian Research 115, 97-117.

Davis, W. J. (1992). Granitoid geochemistry and crustal evolution in the central Slave Province. PhD thesis, Memorial University of Newfoundland, St John's, NL.

Davis, W. J. \& Bleeker, W. (1999). Timing of plutonism, deformation, and metamorphism in the Yellowknife Domain, Slave Province, Canada. Canadian Journal of Earth Sciences 36, 1169-1187.

Davis, W. J. \& Hegner, E. (1992). Neodymium isotopic evidence for the tectonic assembly of Late Archean crust in the Slave Province, northwest Canada. Contributions to Mineralogy and Petrology 111, 493-504.

Davis, W. J., Fryer, B. J. \& King, J. E. (1994). Geochemistry and evolution of late Archean plutonism and its significance to the tectonic development of the Slave craton. Precambrian Research 67, 207-241.

Dawson, K. R. (1966). A comprehensive study of Preissac-Lacorne batholith, Abitibi county, Quebec. Geological Survey of Canada Bulletin 142, 1-76.

Day, W. C. \& Weiblen, P. W. (1986). Origin of late Archean granite: geochemical evidence from the Vermilion granitic complex of northern Minnesota. Contributions to Mineralogy and Petrology 93, 283-296.

De, S. K., Chacko, T., Creaser, R. A. \& Muehlenbachs, K. (2000). Geochemical and $\mathrm{Nd}-\mathrm{Pb}-\mathrm{O}$ isotope systematics of granites from the Taltson magmatic zone, NE Alberta: implications 
for Early Proterozoic tectonics in western Laurentia. Precambrian Research 102, 221-249.

De Albuquerque, C. A. (1973). Geochemistry of biotites from granitic rocks, northern Portugal. Geochimica et Cosmochimica Acta 37, 1779-1802.

Delavault, H., Chauvel, C., Thomassot, E., Devey, C. W. \& Dazas, B. (2016). Sulfur and lead isotopic evidence of relic Archean sediments in the Pitcairn mantle plume. Proceedings of the National Academy of Sciences of the USA 113, 12952-12956.

DePaolo, D. J. (1981). Neodymium isotopes in the Colorado Front Range and crust-mantle evolution in the Proterozoic. Nature 291, 193-197.

DeWitt, E., Redden, J. A., Burack-Wilson, A. \& Buscher, D. (1986). Mineral Resource Potential and Geology of the Black Hills National Forest, South Dakota and Wyoming. US Geological Survey Bulletin 1580, $135 \mathrm{pp}$.

Dhuime, B., Hawkesworth, C. J., Cawood, P. A. \& Storey, C. D. (2012). A change in the geodynamics of continental growth 3 billion years ago. Science 335, 1334-1336.

Drury, S. A. (1979). Rare-earth and other trace element data bearing on the origin of Archaean granitic rocks from Yellowknife, Northwest Territories. Canadian Journal of Earth Sciences 16, 809-815.

Duarte, K. D., Pereira, E. D., Dall'Agnol, R. \& Lafon, J. M. (1991). Geologia e geocronologia do Granito Mata Surrão-sudoeste de Rio Maria (Pa). Simpósio De Geologia da Amazônia 3, 7-20.

Ducharme, Y., Stevenson, R. K. \& Machado, N. (1997). Sm-Nd geochemistry and $\mathrm{U}-\mathrm{Pb}$ geochronology of the Preissac and Lamotte leucogranites, Abitibi Subprovince. Canadian Journal of Earth Sciences 34, 1059-1071.

Duke, E. F., Papike, J. J. \& Laul, J. C. (1992). Geochemistry of a boron-rich peraluminous granite pluton; the Calamity Peak layered granite-pegmatite complex, Black Hills, South Dakota. Canadian Mineralogist 30, 811-833.

Edelman, N. \& Jaanus-Jiirkkiilii, M. (1983). A plate tectonic interpretation of the Precambrian of the archipelago of southwestern Finland. Geological Survey of Finland Bulletin 325, 4-33.

Ehlers, C., Lindroos, A. \& Selonen, O. (1993). The late Svecofennian granite-migmatite zone of southern Finland: a belt of transpressive deformation and granite emplacement. Precambrian Research 64, 295-309.

Eiler, J. M. (2001). Oxygen isotope variations of basaltic lavas and upper mantle rocks. In: Valley, J. W. \& Cole, D. R. (eds) Stable Isotope Geochemistry. Mineralogical Society of America and Geochemical Society, Reviews in Mineralogy and Geochemistry 43, 319-364.

Eiler, J. M., Baumgartner, L. P. \& Valley, J. W. (1992). Intercrystalline stable isotope diffusion: a fast grain boundary model. Contributions to Mineralogy and Petrology 112, 543-557.

Farina, F., Dini, A., Rocchi, S. \& Stevens, G. (2014). Extreme mineral-scale $\mathrm{Sr}$ isotope heterogeneity in granites by disequilibrium melting of the crust. Earth and Planetary Science Letters 399, 103-115.

Farmer, G. L. \& DePaolo, D. J. (1984). Origin of Mesozoic and Tertiary granite in the western United States and implications for pre-Mesozoic crustal structure: 2. Nd and Sr isotopic studies of unmineralized and $\mathrm{Cu}$ - and Mo-mineralized granite in the Precambrian Craton. Journal of Geophysical Research: Solid Earth 89, 10141-10160.

Farquhar, J., Bao, H. \& Thiemens, M. (2000). Atmospheric influence of Earth's earliest sulfur cycle. Science 289, 756-758.

Farquhar, J., Wing, B. A., McKeegan, K. D., Harris, J. W., Cartigny, P. \& Thiemens, M. H. (2002). Mass-independent sulfur of inclusions in diamond and sulfur recycling on early Earth. Science 298, 2369-2372.

Feng, R. \& Kerrich, R. (1991). Single zircon age constraints on the tectonic juxtaposition of the Archean Abitibi greenstone belt and Pontiac subprovince, Quebec, Canada. Geochimica et Cosmochimica Acta 55, 3437-3441.

Feng, R. \& Kerrich, R. (1992a). Geochemical evolution of granitoids from the Archean Abitibi Southern Volcanic Zone and the Pontiac subprovince, Superior Province, Canada: implications for tectonic history and source regions. Chemical Geology 98, 23-70.

Feng, R. \& Kerrich, R. (1992b). Geodynamic evolution of the southern Abitibi and Pontiac terranes: evidence from geochemistry of granitoid magma series (2700-2630 Ma). Canadian Journal of Earth Sciences 29, 2266-2286.

Feng, R., Fan, J. \& Kerrich, R. (1993). Noble metal abundances and characteristics of six granitic magma series, Archean Abitibi belt, Pontiac subprovince: relationships to metallogeny and overprinting of mesothermal gold deposits. Economic Geology 88, 1376-1401.

Finger, F. \& Schiller, D. (2012). Lead contents of S-type granites and their petrogenetic significance. Contributions to Mineralogy and Petrology 164, 747-755.

Fitzsimons, I. C. W. (2000). A review of tectonic events in the East Antarctic shield and their implications for Gondwana and earlier supercontinents. Journal of African Earth Sciences 31, 3-23.

Flament, N., Coltice, N. \& Rey, P. F. (2008). A case for late-Archaean continental emergence from thermal evolution models and hypsometry. Earth and Planetary Science Letters 275, 326-336.

Flood, R. H. \& Shaw, S. E. (1977). Two "S-type" granite suites with low initial ${ }^{87} \mathrm{Sr} /{ }^{86} \mathrm{Sr}$ ratios from the New England Batholith, Australia. Contributions to Mineralogy and Petrology 61, 163-173.

Frost, C. D., Frost, B. R., Chamberlain, K. R. \& Hulsebosch, T. P. (1998). The late Archean history of the Wyoming province as recorded by granitic magmatism in the Wind River Range, Wyoming. Precambrian Research 89, 145-173.

Front, K. \& Nurmi, P. A. (1987). Characteristics and geological setting of synkinematic Svecokarelian granitoids in southern Finland. Precambrian Research 35, 207-224.

Frost, B. R., Barnes, C. G., Collins, W. J., Arculus, R. J., Ellis, D. J. \& Frost, C. D. (2001). A geochemical classification for granitic rocks. Journal of Petrology 42, 2033-2048.

Frost, B. R., Frost, C. D., Cornia, M., Chamberlain, K. R. \& Kirkwood, R. (2006). The Teton-Wind River domain: a 2.68-2.67 $\mathrm{Ga}$ active margin in the western Wyoming Province. Canadian Journal of Earth Sciences 43, 1489-1510.

Frost, B. R., Swapp, S. M., Frost, C. D., Bagdonas, D. A. \& Chamberlain, K. R. (2018). Neoarchean tectonic history of the Teton Range: record of accretion against the present-day western margin of the Wyoming Province. Geosphere 14, 1008-1030.

Frost, C. D. \& Fanning, C. M. (2006). Archean geochronological framework of the Bighorn Mountains, Wyoming. Canadian Journal of Earth Sciences 43, 1399-1418.

Fru, E. C., Rodríguez, N. P., Partin, C. A., Lalonde, S. V., Andersson, P., Weiss, D. J., El Albani, A., Rodushkin, I. \& Konhauser, K. O. (2016). Cu isotopes in marine black shales record the Great Oxidation Event. Proceedings of the National Academy of Sciences of the USA 113, 4941-4946.

Gable, D. J. \& Sims, P. K. (1969). Geology and regional metamorphism of some high-grade cordierite gneisses, Front Range, Colorado. Geological Society of America, Special Papers 128, 69 pp. 
Gaál, G. \& Gorbatschev, R. (1987). An outline of the Precambrian evolution of the Baltic Shield. Precambrian Research, 35, 15-52.

Gasquet, D., Barbey, P., Adou, M. \& Paquette, J. L. (2003). Structure, $\mathrm{Sr}-\mathrm{Nd}$ isotope geochemistry and zircon $\mathrm{U}-\mathrm{Pb}$ geochronology of the granitoids of the Dabakala area (Côte d'lvoire): evidence for a $2.3 \mathrm{Ga}$ crustal growth event in the Paleoproterozoic of West Africa? Precambrian Research 127, 329-354.

Gehrels, G. (2014). Detrital zircon U-Pb geochronology applied to tectonics. Annual Review of Earth and Planetary Sciences 42, 127-149.

Giletti, B. J. \& Yund, R. A. (1984). Oxygen diffusion in quartz. Journal of Geophysical Research: Solid Earth 89, 4039-4046.

Goad, B. E. \& Černý, P. (1981). Peraluminous pegmatitic granites and their pegmatite aureoles in the Winnipeg River district, southeastern Manitoba. Canadian Mineralogist 19, 177-194.

Gosselin, D. C., Papike, J. J., Zartman, R. E., Peterman, Z. E. \& Laul, J. C. (1988). Archean rocks of the Black Hills, South Dakota: reworked basement from the southern extension of the Trans-Hudson orogen. Geological Society of America Bulletin 100, 1244-1259.

Gosselin, D. C., Papike, J. J., Shearer, C. K., Peterman, Z. E. \& Laul, J. C. (1990). Geochemistry and origin of Archean granites from the Black Hills, South Dakota. Canadian Journal of Earth Sciences 27, 57-71.

Gray, C. M. (1984). An isotopic mixing model for the origin of granitic rocks in southeastern Australia. Earth and Planetary Science Letters 70, 47-60.

Green, D. C. \& Baadsgaard, H. (1971). Temporal evolution and petrogenesis of an Archaean crustal segment at Yellowknife, NWT, Canada. Journal of Petrology 12, 177-217.

Green, D. C., Baadsgaard, H. \& Cumming, G. L. (1968). Geochronology of the Yellowknife area, Northwest Territories, Canada. Canadian Journal of Earth Sciences 5, 725-735.

Green, T. H. (1977). Garnet in silicic liquids and its possible use as a PT indicator. Contributions to Mineralogy and Petrology 65, 59-67.

Grotzinger, J. P. \& James, N. P. (2000). Precambrian carbonates: evolution of understanding. In: Grotzinger, J. P. \& James, N. P. (eds) Carbonate Sedimentation and Diagenesis in the Evolving Precambrian World. Society for Sedimentary Geology, Special Publications 67, 3-20.

Grove, T. L. \& Parman, S. W. (2004). Thermal evolution of the Earth as recorded by komatiites. Earth and Planetary Science Letters 219, 173-187.

Grover, T. W., Pattison, D. R. M., McDonough, M. R. \& McNicoll, V. J. (1997). Tectonometamorphic evolution of the southern Taltson Magmatic Zone and associated shear zones, Northeastern Alberta. Canadian Mineralogist 35, 1051-1067.

Gumsley, A. P., Chamberlain, K. R., Bleeker, W., Söderlund, U., de Kock, M. O., Larsson, E. R. \& Bekker, A. (2017). Timing and tempo of the Great Oxidation Event. Proceedings of the National Academy of Sciences of the USA 114, 1811-1816.

Guo, J.-H., Zhai, M.-G. \& Xu, R.-H. (2001). Timing of the granulite-facies metamorphism in the Sanggan area, North China craton: zircon U-Pb geochronology. Science in China Series D: Earth Sciences 44, 1010-1018.

Guo, Q., Strauss, H., Kaufman, A. J., Schröder, S., Gutzmer, J., Wing, B., Baker, M. A., Bekker, A., Jin, Q., Kim, S. T. \& Farquhar, J. (2009). Reconstructing Earth's surface oxidation across the Archean-Proterozoic transition. Geology 37, 399-402.
Hall, A. \& Tyler, R. C. (1965). The origin of accessory garnet in the Donegal granite. Mineralogical Magazine and Journal of the Mineralogical Society 35, 628-633.

Halla, J., Whitehouse, M. J., Ahmad, T. \& Bagai, Z. (2017). Archaean granitoids: an overview and significance from a tectonic perspective. In: Betterton, J., Craig, J., Mendum, J. R., Neller, R. \& Tanner, J. (eds) Aspects of the Life and Works of Archibald Geikie. Geological Society, London, Special Publications 449, 1-18.

Hammouda, T., Pichavant, M. \& Chaussidon, M. (1996). Isotopic equilibration during partial melting: an experimental test of the behaviour of Sr. Earth and Planetary Science Letters 144, 109-121.

Harris, N. B. W. \& Inger, S. (1992). Trace element modelling of pelite-derived granites. Contributions to Mineralogy and Petrology, 110, 46-56.

Harris, N., Massey, J. \& Inger, S. (1993). The role of fluids in the formation of High Himalayan leucogranites. In: Treloar, P. J. \& Searle, M. P. (eds) Himalayan Tectonics. Geological Society, London, Special Publications 74, 391-400.

Harris, N., Ayres, M. \& Massey, J. (1995). Geochemistry of granitic melts produced during the incongruent melting of muscovite: implications for the extraction of Himalayan leucogranite magmas. Journal of Geophysical Research: Solid Earth 100, 15767-15777.

Harrison, T. M. \& Watson, E. B. (1984). The behavior of apatite during crustal anatexis: equilibrium and kinetic considerations. Geochimica et Cosmochimica Acta 48, 1467-1477.

Hausel, W. D. (1991). Economic geology of the South Pass granite greenstone belt, southern Wind River Range, western Wyoming. Geological Survey of Wyoming Report of Investigations 44, $129 \mathrm{pp}$.

Hazen, R. M., Papineau, D., Bleeker, W., Downs, R. T., Ferry, J. M., McCoy, T. J., Sverjensky, D. A. \& Yang, H. (2008). Mineral evolution. American Mineralogist 93, 1693-1720.

Hazen, R. M., Sverjensky, D. A., Azzolini, D., Bish, D. L., Elmore, S. C., Hinnov, L. \& Milliken, R. E. (2013). Clay mineral evolution. American Mineralogist 98, 2007-2029.

Healy, B., Collins, W. J. \& Richards, S. W. (2004). A hybrid origin for Lachlan S-type granites: the Murrumbidgee Batholith example. Lithos 78, 197-216.

Hegner, E., Kröner, A. \& Hofmann, A. W. (1984). Age and isotope geochemistry of the Archaean Pongola and Usushwana Suites in Swaziland, southern Africa. Earth and Planetary Science Letters 70, 267-279.

Helms, T. S. \& Labotka, T. C. (1991). Petrogenesis of Early Proterozoic pelitic schists of the southern Black Hills, South Dakota: constraints on regional low-pressure metamorphism. Geological Society of America Bulletin 103, 1324-1334.

Henderson, J. B. (1972). Sedimentology of Archean turbidites at Yellowknife, Northwest Territories. Canadian Journal of Earth Sciences 9, 882-902.

Henderson, J. B. (1985). Geology of the Yellowknife-Hearne Lake Area, District of Mackenzie: A Segment across an Archean Basin. Geological Survey of Canada Memoir 414, $135 \mathrm{pp}$.

Herzberg, C., Condie, K. \& Korenaga, J. (2010). Thermal history of the Earth and its petrological expression. Earth and Planetary Science Letters 292, 79-88.

Hildebrand, R. S., Hoffman, P. F. \& Bowring, S. A. (1987). Tectono-magmatic evolution of the 1.9-Ga Great Bear magmatic zone, Wopmay Orogen, northwestern Canada. Journal of Volcanology and Geothermal Research 32, 99-118.

Hill, R. I., Chappell, B. W. \& Campbell, I. H. (1992). Late Archaean granites of the southeastern Yilgarn Block, Western Australia: age, geochemistry, and origin. Earth and 
Environmental Science Transactions of the Royal Society of Edinburgh 83, 211-226.

Hirdes, W., Davis, D. W., Lüdtke, G. \& Konan, G. (1996). Two generations of Birimian (Paleoproterozoic) volcanic belts in northeastern Côte d'Ivoire (West Africa): consequences for the Birimian controversy. Precambrian Research 80, 173-191.

Hoffman, P. F. (1980). Wopmay Orogen: a Wilson cycle of Early Proterozoic age in the northwest of the Canadian Shield. Geoscience Canada 6, 523-549.

Hoffman, P. F. (1988). United Plates of America. Annual Review of Earth and Planetary Sciences 16, 543-603.

Hoffman, P. F. \& Bowring, S. A. (1984). Short-lived 1.9 Ga continental margin and its destruction, Wopmay orogen, northwest Canada. Geology 12, 68-72.

Hoffman, P. F., St Onge, M. R., Easton, R. M., Grotzinger, J. \& Schulze, D. E. (1980). Syntectonic Plutonism in North-Central Wopmay Orogen (Early Proterozoic), Hepburn Lake Map Area. Geological Survey of Canada, Current Research Part A, District of Mackenzie, 80, 171-177.

Hogan, J. P. \& Sinha, A. K. (1991). The effect of accessory minerals on the redistribution of lead isotopes during crustal anatexis: a model. Geochimica et Cosmochimica Acta 55, 335-348.

Holdaway, M. J. (2000). Application of new experimental and garnet Margules data to the garnet-biotite geothermometer. American Mineralogist, 85, 881-892.

Holland, H. D. (1984). The Chemical Evolution of the Atmosphere and Oceans. Princeton, NJ: Princeton University Press, 598 pp.

Holland, H. D. (2002). Volcanic gases, black smokers, and the great oxidation event. Geochimica et Cosmochimica Acta 66, 3811-3826.

Holland, H. D. (2005). 100th anniversary special paper: sedimentary mineral deposits and the evolution of Earth's near-surface environments. Economic Geology 100, 1489-1509.

Holland, H. D. (2006). The oxygenation of the atmosphere and oceans. Philosophical Transactions of the Royal Society of London, Series B 361, 903-915.

Holtz, F., Johannes, W. \& Pichavant, M. (1992). Peraluminous granites: the effect of alumina on melt composition and coexisting minerals. Earth and Environmental Science Transactions of the Royal Society of Edinburgh 83, 409-416.

Hopgood, A. M., Bowes, D. R. \& Addison, J. (1976). Structural development of migmatites near Skåldö, southwest Finland. Bulletin of the Geological Society of Finland 48, 43-62.

Hopkinson, T. N., Harris, N. B. W., Warren, C. J., Spencer, C. J., Roberts, N. M. W., Horstwood, M. S. A. \& Parrish, R. R. (2017). The identification and significance of pure sediment-derived granites. Earth and Planetary Science Letters 467, 57-63.

Huhma, $\mathrm{H}$. (1986). Sm-Nd, U-Pb and $\mathrm{Pb}-\mathrm{Pb}$ isotopic evidence for the origin of the Early Proterozoic Svecofennian crust in Finland. Geological Survey of Finland Bulletin 337, 48 pp.

Icenhower, J. \& London, D. (1995). An experimental study of element partitioning among biotite, muscovite, and coexisting peraluminous silicic melt at $200 \mathrm{MPa}\left(\mathrm{H}_{2} \mathrm{O}\right)$. American Mineralogist 80, 1229-1251.

Ishihara, S. (1977). The magnetite-series and ilmenite-series granitic rocks. Mining Geology 27, 293-305.

Ishihara, S. \& Sasaki, A. (1989). Sulfur isotopic ratios of the magnetite-series and ilmenite-series granitoids of the Sierra Nevada batholith—a reconnaissance study. Geology 17, 788-791.

Ishihara, S., Robb, L. J., Anhaeusser, C. R. \& Imai, A. (2002). Granitoid series in terms of magnetic susceptibility: a case study from the Barberton region, South Africa. Gondwana Research 5, 581-589.

Jaguin, J., Moyen, J. F., Boulvais, P., Poujol, M., Tyler, I. M. \& Knox, R. (2010). Mid-Archean granites south of the Murchison Greenstone Belt, South Africa: the oldest large biotite-muscovite leucogranite bodies. In: Tyler, I. M. \& Robinson, K. (eds) Abstracts, Fifth International Archean Symposium. Perth, WA: Geological Survey of Western Australia, p. 78.

Jaguin, J., Gapais, D., Poujol, M., Boulvais, P. \& Moyen, J. F. (2012). The Murchison greenstone belt (South Africa): a general tectonic framework. South African Journal of Geology $115,65-76$.

Jin, M.-S., Lee, Y. S. \& Ishihara, S. (2001). Granitoids and magnetic susceptibility in South Korea. Resource Geology 51, 189-203.

Johannes, W., Ehlers, C., Kriegsman, L. M. \& Mengel, K. (2003). The link between migmatites and S-type granites in the Turku area, southern Finland. Lithos 68, 69-90.

Johnston, D. T. (2011). Multiple sulfur isotopes and the evolution of Earth's surface sulfur cycle. Earth-Science Reviews 106, 161-183.

Joshi, K. B., Bhattacharjee, J., Rai, G., Halla, J., Ahmad, T., Kurhila, M., Heilimo, E. \& Choudhary, A. K. (2017). The diversification of granitoids and plate tectonic implications at the Archaean-Proterozoic boundary in the Bundelkhand Craton, Central India. In: Halla, J., Whitehouse, M. J., Ahmad, T. \& Bagai, Z. (eds) Crust-Mantle Interactions and Granitoid Diversification: Insights from Archaean Cratons. Geological Society, London, Special Publications 449, 123-157.

Joyce, A. S. (1973). Chemistry of the minerals of the granitic Murrumbidgee batholith, Australian Capital Territory. Chemical Geology 11, 271-296.

Karlstrom, K. E., Åhäll, K. I., Harlan, S. S., Williams, M. L., McLelland, J. \& Geissman, J. W. (2001). Long-lived $(1.8-1.0 \mathrm{Ga})$ convergent orogen in southern Laurentia, its extensions to Australia and Baltica, and implications for refining Rodinia. Precambrian Research 111, 5-30.

Kasting, J. F. (2001). The rise of atmospheric oxygen. Science 293, 819-820.

Kay, S. V. \& Stott, G. M. (1985). Economic geology of the Lake St. Joseph area. Summary of Field Work and Other Activities 1985, Ontario Geological Survey, Miscellaneous Paper 126, 26-35.

Kendall, B., Brennecka, G. A., Weyer, S. \& Anbar, A. D. (2013). Uranium isotope fractionation suggests oxidative uranium mobilization at 2.50 Ga. Chemical Geology 362, 105-114.

King, E. M. \& Valley, J. W. (2001). The source, magmatic contamination, and alteration of the Idaho batholith. Contributions to Mineralogy and Petrology 142, 72-88.

Keller, B. \& Schoene, B. (2018). Plate tectonics and continental basaltic geochemistry throughout Earth history. Earth and Planetary Science Letters 481, 290-304.

Keller, C. B. \& Schoene, B. (2012). Statistical geochemistry reveals disruption in secular lithospheric evolution about 2.5 Gyr ago. Nature 485, 490-493.

Kemp, A. I. S., Hawkesworth, C. J., Paterson, B. A., Foster, G. L., Kinny, P. D., Whitehouse, M. J. \& Maas, R. (2006). Exploring the plutonic-volcanic link: a zircon $\mathrm{U}-\mathrm{Pb}, \mathrm{Lu}-\mathrm{Hf}$ and $\mathrm{O}$ isotope study of paired volcanic and granitic units from southeastern Australia. Transactions of the Royal Society of Edinburgh: Earth Sciences 97, 337-355.

Kemp, A. I. S., Hawkesworth, C. J., Foster, G. L., Paterson, B. A., Woodhead, J. D., Hergt, J. M., Gray, C. M. \& Whitehouse, M. J. (2007). Magmatic and crustal differentiation history of granitic rocks from $\mathrm{Hf}-\mathrm{O}$ isotopes in zircon. Science 315, 980-983. 
Kim, J. \& Cho, M. (2003). Low-pressure metamorphism and leucogranite magmatism, northeastern Yeongnam Massif, Korea: implication for Paleoproterozoic crustal evolution. Precambrian Research 122, 235-251.

Kim, N., Cheong, C. S., Park, K. H., Kim, J. \& Song, Y. S. (2012). Crustal evolution of northeastern Yeongnam Massif, Korea, revealed by SHRIMP U-Pb zircon geochronology and geochemistry. Gondwana Research 21, 865-875.

King, J. E. (1986). The metamorphic internal zone of Wopmay orogen (Early Proterozoic), Canada: $30 \mathrm{~km}$ of structural relief in a composite section based on plunge projection. Tectonics 5, 973-994.

King, J. E., Davis, W. J. \& Relf, C. (1992). Late Archean tectono-magmatic evolution of the central Slave Province, Northwest Territories. Canadian Journal of Earth Sciences 29, 2156-2170.

Kirby, E., Karlstrom, K. E., Andronicos, C. L. \& Dallmeyer, R. D. (1995). Tectonic setting of the Sandia pluton: An orogenic $1.4 \mathrm{Ga}$ granite in New Mexico. Tectonics 14, 185-201.

Knesel, K. M. \& Davidson, J. P. (2002). Insights into collisional magmatism from isotopic fingerprints of melting reactions. Science 296, 2206-2208.

Korenaga, J. (2008). Urey ratio and the structure and evolution of Earth's mantle. Reviews of Geophysics 46, RG2007.

Korja, A. \& Heikkinen, P. (1995). Proterozoic extensional tectonics of the central Fennoscandian Shield: results from the Baltic and Bothnian echoes from the lithosphere experiment. Tectonics 14, 504-517.

Korsman, K., H., Hautala, T. \& Wasenius, P. (1984). Metamorphism as an indicator of evolution and structure of the crust in eastern Finland. Geological Survey of Finland Bulletin 328, 40 pp.

Kretz, R. (1968). Study of pegmatite bodies and enclosing rocks, Yellowknife-Beaulieu region, District of Mackenzie. Geological Survey of Canada Bulletin 159, 109 pp.

Kretz, R. (1985). Chemical composition of the Sparrow pluton and associated pegmatite dikes. Contributions to the Geology of the Northwest Territories 2, 1-13.

Kretz, R., Garrett, D. \& Garrett, R. G. (1982). Na-K-Li geochemistry of the Prestige pluton in the Slave Province of the Canadian Shield. Canadian Journal of Earth Sciences 19, 540-554.

Kretz, R., Loop, J. \& Hartree, R. (1989). Petrology and Li-Be-B geochemistry of muscovite-biotite granite and associated pegmatite near Yellowknife, Canada. Contributions to Mineralogy and Petrology 102, 174-190.

Kump, L. R. \& Barley, M. E. (2007). Increased subaerial volcanism and the rise of atmospheric oxygen 2.5 billion years ago. Nature 448, 1033-1036.

Kump, L. R., Kasting, J. F. \& Barley, M. E. (2001). Rise of atmospheric oxygen and the 'upside-down' Archean mantle. Geochemistry Geophysics. Geosystems 2, 1025.

Lahtinen, R. (1994). Crustal evolution of the Svecofennian and Karelian domains during 2.1-1.79 Ga, with special emphasis on the geochemistry and origin of 1.93-1.91 Ga gneissic tonalites and associated supracrustal rocks in the Rauta-lampi area, central Finland. Geological Survey of Finland, Bulletin 378, 128.

Lahtinen, R., Korja, A. \& Nironen, M. (2005). Paleoproterozoic tectonic evolution. In: Lehtinen, M., Nurmi, P. A. \& Rämö, O. T. (eds) Developments in Precambrian Geology 14, 481-531.

Lalonde, A. E. (1986). The intrusive rocks of the Hepburn metamorphic-plutonic zone of the central Wopmay orogen, N.W.T. PhD thesis, McGill University, Montreal, ON, 258 pp.

Lalonde, A. E. (1989). Hepburn intrusive suite: Peraluminous plutonism within a closing back-arc basin, Wopmay orogen, Canada. Geology 17, 261-264.
Lalonde, A. E. \& Bernard, P. (1993). Composition and color of biotite from granites; two useful properties in characterization of plutonic suites from the Hepburn internal zone of Wopmay Orogen, Northwest Territories. Canadian Mineralogist 31, 203-217.

Lan, Z.-W. (2007). Petrogenesis of garnet-bearing granites in the khondalites of North China Craton: mixing mechanism of melt and restite. Master's Degree thesis, Institute of Geology and Geophysics, Chinese Academy of Sciences, Beijing, 43 pp.

Langford, F. F. \& Morin, J. A. (1976). The development of the Superior Province of northwestern Ontario by merging island arcs. American Journal of Science 276, 1023-1034.

Langstaff, G. D. (1995). Archean Geology of the Granite Mountains, Wyoming. Ph.D. dissertation, Golden, Colorado, Colorado School of Mines, $671 \mathrm{p}$.

Larbi, Y., Stevenson, R., Breaks, F., Machado, N. \& Gariépy, C. (1999). Age and isotopic composition of late Archean leucogranites: implications for continental collision in the western Superior Province. Canadian Journal of Earth Sciences 36, 495-510.

Laurent, O., Martin, H., Moyen, J. F. \& Doucelance, R. (2014). The diversity and evolution of late-Archean granitoids: evidence for the onset of 'modern-style' plate tectonics between 3.0 and 2.5 Ga. Lithos 205, 208-235.

Leal, L. R. B., Teixeira, W., Cunha, J. C., Leal, A. B. D. M., Macambira, M. J. B. \& Rosa, M. D. L. D. S. (2000). Isotopic signatures of Paleoproterozoic granitoids of the Gavião block and implications for the evolution of the São Francisco craton, Bahia, Brazil. Revista Brasileira de Geociências 30, 066-069.

Le Breton, N. \& Thompson, A. B. (1988). Fluid-absent (dehydration) melting of biotite in metapelites in the early stages of crustal anatexis. Contributions to Mineralogy and Petrology 99, 226-237.

Lee, C. T. A. \& Bachmann, O. (2014). How important is the role of crystal fractionation in making intermediate magmas? Insights from $\mathrm{Zr}$ and $\mathrm{P}$ systematics. Earth and Planetary Science Letters 393, 266-274.

Lee, S. G., Shin, S. C., Jin, M. S., Ogasawara, M. \& Yang, M. K. (2005). Two Paleoproterozoic strongly peraluminous granitic plutons (Nonggeori and Naedeokri granites) at the northeastern part of Yeongnam Massif, Korea: Geochemical and isotopic constraints in East Asian crustal formation history. Precambrian Research 139, 101-120.

Leube, A., Hirdes, W., Mauer, R. \& Kesse, G. O. (1990). The early Proterozoic Birimian Supergroup of Ghana and some aspects of its associated gold mineralization. Precambrian Research 46, 139-165.

London, D. (1992). Phosphorus in S-type magmas: the $\mathrm{P}_{2} \mathrm{O}_{5}$ content of feldspars from peraluminous granites, pegmatites, and rhyolites. American Mineralogist 77, 126-145.

London, D., Cerny, P., Loomis, J. \& Pan, J. J. (1990). Phosphorus in alkali feldspars of rare-element granitic pegmatites. Canadian Mineralogist 28, 771-786.

Longstaffe, F. J., Cerny, P. \& Muehlenbachs, K. (1981). Oxygen-isotope geochemistry of the granitoid rocks in the Winnipeg River pegmatite district, southeastern Manitoba. Canadian Mineralogist 19, 195-204.

Longstaffe, F. J. \& Schwarcz, H. P. (1977). sol180160 of Archean clastic metasedimentary rocks: a petrogenetic indicator for Archean gneisses? Geochimica et Cosmochimica Acta 41, 1303-1312.

Lowe, D. R. (1994). Archean greenstone-related sedimentary rocks. In: Condie, K. C. (ed.) Archaean Crustal Evolution, Developments in Precambrian Geology, 11. Amsterdam: Elsevier, pp. 121-169. 
Ludwig, K. R. \& Stuckless, J. S. (1978). Uranium-lead isotope systematics and apparent ages of zircons and other minerals in Precambrian granitic rocks, Granite Mountains, Wyoming. Contributions to Mineralogy and Petrology 65, 243-354.

Lyons, T. W., Reinhard, C. T. \& Planavsky, N. J. (2014). The rise of oxygen in Earth's early ocean and atmosphere. Nature 506, 307-315.

Madore, C. \& Annesley, I. R. (1996). Wollaston EAGLE Project, Basal Wollaston Group: Facies (Segment 2). In: Annesley, R., Madore, C., Shi, R., Quirt, D. H., Dyck, J., Hajnal, Z. \& Reilkoff, B. (eds) Wollaston EAGLE Project: Segment 2 Report. Saskatchewan Research Council Publication R-1420-5-C-96, 1-122.

Maphalala, R. M. \& Kröner, A. (1993). Pb-Pb single zircon ages for the younger Archaean granitoids of Swaziland, southern Africa. In: Abstracts of 16th Cochrane Colloquium, African Geology, Mbabane, Swaziland, 2, pp. 201-206.

Marinho, M. M., Sabaté, P. \& Barbosa, J. S. F. (1993). The Contendas-Mirante volcano-sedimentary belt. In: Figueirêdo, M. C. H. \& Pedreira, A. J. (eds) Petrological and Geochronologic Evolution of the Oldest Segments of the São Francisco Craton. Boletim de Instituto de Geociências da Universidade de São Paulo. Bull IG-USP, 17, 37-72.

Marschall, H. R., Hawkesworth, C. J., Storey, C. D., Dhuime, B., Leat, P. T., Meyer, H. P. \& Tamm-Buckle, S. (2010). The Annandagstoppane Granite, East Antarctica: evidence for Archaean intracrustal recycling in the Kaapvaal-Grunehogna Craton from zircon $\mathrm{O}$ and $\mathrm{Hf}$ isotopes. Journal of Petrology 51, 2277-2301.

Martin, H., Moyen, J. F. \& Rapp, R. (2009). The sanukitoid series: magmatism at the Archaean-Proterozoic transition. Earth and Environmental Science Transactions of the Royal Society of Edinburgh 100, 15-33.

Matthews, P. E. (1985). Archaean post-Pongola granites in the southeastern Kaapvaal Craton. South African Journal of Science 81, 479-484.

McCombs, J. A., Dahl, P. S. \& Hamilton, M. A. (2004). U-Pb ages of Neoarchean granitoids from the Black Hills, South Dakota, USA: implications for crustal evolution in the Archean Wyoming province. Precambrian Research 130, 161-184.

McCulloch, M. T. \& Bennett, V. C. (1994). Progressive growth of the Earth's continental crust and depleted mantle: Geochemical constraints. Geochimica et Cosmochimica Acta 58, 4717-4738.

McKechnie, C. L., Annesley, I. R. \& Ansdell, K. M. (2012a). Radioactive abyssal granitic pegmatites and leucogranites in the Wollaston Domain, northern Saskatchewan, Canada: Mineral compositions and conditions of emplacement in the Fraser Lakes area. Canadian Mineralogist 50, 1637-1667.

McKechnie, C. L., Annesley, I. R. \& Ansdell, K. M. (2012b). Medium- to low-pressure pelitic gneisses of Fraser Lakes Zone B, Wollaston Domain, northern Saskatchewan, Canada: mineral compositions, metamorphic $P-T-t$ path, and implications for the genesis of radioactive abyssal granitic pegmatites. Canadian Mineralogist 50, 1669-1694.

McKechnie, C. L., Annesley, I. R. \& Ansdell, K. M. (2013). Geological setting, petrology, and geochemistry of granitic pegmatites and leucogranites hosting U-Th-REE mineralization at Fraser Lakes zone B, Wollaston Domain, northern Saskatchewan, Canada. Exploration and Mining Geology 21, 1-26.

McNicoll, V. J., McDonough, M. \& Grover, T. (1993). Preliminary $\mathrm{U}-\mathrm{Pb}$ geochronology of the Southern Taltson Magmatic Zone, Northeastern Alberta. In: Ross, G. M. (ed.)
Report of Lithoprobe Alberta Basement Transects Workshop. Lithoprobe Report 31, 129-130.

McNicoll, V. J., McDonough, M. \& Grover, T. (1994). U-Pb geochronology of the Southern Taltson Magmatic Zone, Northeastern Alberta. In: Ross, G. M. (ed.) Report of Lithoprobe Alberta Basement Transects Workshop. Lithoprobe Report 37, 270-273.

Meintzer, R. E. (1987). The mineralogy and geochemistry of the granitoid rocks and related pegmatites of the Yellowknife Pegmatite Field, Northwest Territories. PhD thesis, University of Manitoba, Winnipeg, MB.

Meintzer, R. E., Wise, M. A. \& Černý, P. (1984). Distribution and structural setting of fertile granites and related pegmatites in the Yellowknife pegmatite field, District of Mackenzie. Current Research, Part A. Geological Survey of Canada, Paper 84-1A, 373-381.

Meredith, M. T. (2005). A Late Archean tectonic boundary exposed at Tin Cup Mountain, Granite Mountains, Wyoming. MS thesis, University of Wyoming, Laramie, WY.

Meyer, F. M., Robb, L. J., Reimold, W. U. \& De Bruiyn, H. (1994). Contrasting low- and high-Ca granites in the Archean Barberton Mountain Land, southern Africa. Lithos 32, 63-76.

Mikkola, P., Lauri, L. S. \& Käpyaho, A. (2012). Neoarchean leucogranitoids of the Kianta Complex, Karelian Province, Finland: source characteristics and processes responsible for the observed heterogeneity. Precambrian Research 206, 72-86.

Miller, C. F. \& Stoddard, E. F. (1981). The role of manganese in the paragenesis of magmatic garnet: an example from the Old Woman-Piute Range, California. Journal of Geology 89, 233-246.

Miller, C. F., Stoddard, E. F., Bradfish, L. J. \& Dollase, W. A. (1981). Composition of plutonic muscovite; genetic implications. Canadian Mineralogist 19, 25-34.

Miller, C. F., McDowell, S. M. \& Mapes, R. W. (2003). Hot and cold granites? Implications of zircon saturation temperatures and preservation of inheritance. Geology 31, 529-532.

Mogk, D. W., Mueller, P. A. \& Wooden, J. L. (1988). Archean tectonics of the North Snowy Block, Beartooth Mountains, Montana. Journal of Geology 96, 125-141.

Mogk, D. W., Mueller, P. A. \& Wooden, J. L. (1992). The nature of Archean terrane boundaries: an example from the northern Wyoming Province. Precambrian Research 55, 155-168.

Montel, J. M. \& Vielzeuf, D. (1997). Partial melting of metagreywackes, Part II. Compositions of minerals and melts. Contributions to Mineralogy and Petrology 128, 176-196.

Morfin, S., Sawyer, E. W. \& Bandyayera, D. (2013). Large volumes of anatectic melt retained in granulite facies migmaties: An injection complex in northern Quebec. Lithos 168-169, 200-218.

Moyen, J. F., Martin, H., Jayananda, M. \& Auvray, B. (2003). Late Archaean granites; a typology based on the Dharwar Craton, India. Precambrian Research 127, 103-123.

Mueller, P., Wooden, J., Nutman, A. \& Mogk, D. (1998). Early Archean crust in the northern Wyoming province: evidence from U-Pb systematics in detrital zircons. Precambrian Research 91, 295-307.

Mueller, P. A. \& Frost, C. D. (2006). The Wyoming Province: a distinctive Archean craton in Laurentian North America. Canadian Journal of Earth Sciences 43, 1391-1397.

Mueller, P. A., Shuster, R. D., Wooden, J. L., Erslev, E. A. \& Bowes, D. R. (1993). Age and composition of Archean crystalline rocks from the southern Madison Range, Montana: Implications for crustal evolution in the Wyoming craton. Geological Society of America Bulletin 105, 437-446. 
Mueller, P. A., Wooden, J. L., Mogk, D. W., Nutman, A. P. \& Williams, I. S. (1996). Extended history of a $3.5 \mathrm{Ga}$ trondhjemitic gneiss, Wyoming province, USA: evidence from $\mathrm{U}-\mathrm{Pb}$ systematics in zircon. Precambrian Research 78, 41-52.

Mulja, T., Williams-Jones, A. E., Wood, S. A. \& Boily, M. (1995a). The rare-element-enriched monzogranite- pegmatite-quartz vein systems in the Preissac-Lacorne Batholith, Quebec; I, Geology and mineralogy. Canadian Mineralogist 33, 793-815.

Mulja, T., Williams-Jones, A. E., Wood, S. A. \& Boily, M. (1995b). The rare-element-enriched monzogranite- pegmatite-quartz vein systems in the Preissac-Lacorne Batholith, Quebec; II, Geochemistry and petrogenesis. Canadian Mineralogist 33, 817-833.

Mysen, B. O., Ryerson, F. J. \& Virgo, D. (1981). The structural role of phosphorus in silicate melts. American Mineralogist 66, 106-117.

Mysen, B. O. (1998). Phosphorus solubility mechanisms in haplogranitic aluminosilicate glass and melt: Effect of temperature and aluminum content. Contributions to Mineralogy and Petrology 133, 38-50.

Nabelek, P. I. 2019. Petrogenesis of leucogranites in collisional orogens. Geological Society, London, Special Publications 491, SP491-2018.

Nabelek, P. I. \& Bartlett, C. D. (1998). Petrologic and geochemical links between the post-collisional Proterozoic Harney Peak leucogranite, South Dakota, USA, and its source rocks. Lithos 45, 71-85.

Nabelek, P. I. \& Glascock, M. D. (1995). REE-depleted leucogranites, Black Hills, South Dakota: a consequence of disequilibrium melting of monazite-bearing schists. Journal of Petrology 36, 1055-1071.

Nabelek, P. I., Russ-Nabelek, C. \& Denison, J. R. (1992a). The generation and crystallization conditions of the Proterozoic Harney Peak leucogranite, Black Hills, South Dakota, USA: petrologic and geochemical constraints. Contributions to Mineralogy and Petrology 110, 173-191.

Nabelek, P. I., Russ-Nabelek, C. \& Haeussler, G. T. (1992b). Stable isotope evidence for the petrogenesis and fluid evolution in the Proterozoic Harney Peak leucogranite, Black Hills, South Dakota. Geochimica et Cosmochimica Acta 56, 403-417.

Nabelek, P. I., Sirbescu, M. \& Liu, M. (1999). Petrogenesis and tectonic context of the Harney Peak Granite, Black Hills, South Dakota. Rocky Mountain Geology 34, 165-181.

Nabelek, P. I., Liu, M. \& Sirbescu, M. L. (2001). Thermo-rheological, shear heating model for leucogranite generation, metamorphism, and deformation during the Proterozoic Trans-Hudson orogeny, Black Hills, South Dakota. Tectonophysics 342, 371-388.

Nelson, B. K. \& DePaolo, D. J. (1985). Rapid production of continental crust 1.7 to 1.9 by ago: Nd isotopic evidence from the basement of the North American mid-continent. Geological Society of America Bulletin 96, 746-754.

Nicoli, G., Stevens, G., Moyen, J. F. \& Frei, D. (2015). Rapid evolution from sediment to anatectic granulite in an Archean continental collision zone: the example of the Bandelierkop Formation metapelites, South Marginal Zone, Limpopo Belt, South Africa. Journal of Metamorphic Geology 33, 177-202.

Nicoli, G., Stevens, G., Moyen, J. F., Vezinet, A. \& Mayne, M. (2017). Insights into the complexity of crustal differentiation: $\mathrm{K}_{2} \mathrm{O}$-poor leucosomes within metasedimentary migmatites from the Southern Marginal Zone of the Limpopo Belt, South Africa. Journal of Metamorphic Geology 35, 999-1022.

Nironen, M. (1997). The Svecofennian Orogen: a tectonic model. Precambrian Research 86, 21-44.
Nutman, A. P. \& Cordani, U. G. (1993). SHRIMP U-Pb zircon geochronology of Archean granitoids from the Contendas-Mirante area of the São Francisco Craton, Bahia, Brazil. Precambrian Research 63, 179-188.

Nutman, A. P., Cordani, U. G. \& Sabaté, P. (1994). SHRIMP U-Pb ages of detrital zircons from the Early Proterozoic Contendas-Mirante supracrustal belt, São Francisco Craton, Bahia, Brazil. Journal of South American Earth Science 7, 109-114.

Nyman, M. W. \& Karlstrom, K. E. (1997). Pluton emplacement processes and tectonic setting of the $1.42 \mathrm{Ga}$ Signal batholith, SW USA: important role of crustal anisotropy during regional shortening. Precambrian Research 82, 237-263.

Nyman, M. W., Karlstrom, K. E., Kirby, E. \& Graubard, C. M. (1994). Mesoproterozoic contractional orogeny in western North America: Evidence from ca. $1.4 \mathrm{Ga}$ plutons. Geology 22, 901-904.

Och, L. M. \& Shields-Zhou, G. A. (2012). The Neoproterozoic oxygenation event: environmental perturbations and biogeochemical cycling. Earth-Science Reviews 110, 26-57.

Palmer, E. M. (2018). Petrogenesis of the Archean Prestige leucogranites and spatially associated LCT pegmatites, NWT: Insights from whole-rock and muscovite trace element geochemistry and apatite $\mathrm{U}-\mathrm{Pb}$ geochronology. MSc thesis, University of New Brunswick, Fredericton, NB.

Palmer, E. M., Lentz, D. R. \& Falck, H. (2016). Field and lithogeochemical data for the Prestige pluton and surrounding pegmatites, NWT, Canada. Northwest Territories Geological Survey, Yellowknife, NWT Open Report 2016-003, 16 pp.

Pan, Y. \& Breaks, F. W. (1997). Rare-earth elements in fluorapatite, Separation Lake area, Ontario: Evidence for S-type granite-rare-element pegmatite linkage. Canadian Mineralogist 35, 659-671.

Pan, Y., Therens, C. \& Breaks, F. (1997). Geochemistry of granitoids in the English River Subprovince, Separation Lake area. 1997 Western Superior Transect Third Annual Workshop, April 11-12, 1997. Lithoprobe Report 63, 55-61.

Paris, G., Adkins, J. F., Sessions, A. L., Webb, S. M. \& Fischer, W. W. (2014). Neoarchean carbonate-associated sulfate records positive $\Delta^{33}$ S anomalies. Science 346, 739-741.

Patiño Douce, A. E. \& Beard, J. S. (1995). Dehydration-melting of biotite gneiss and quartz amphibolite from 3 to $15 \mathrm{kbar}$. Journal of Petrology 36, 707-738.

Patiño Douce, A. E. \& Harris, N. (1998). Experimental constraints on Himalayan anatexis. Journal of Petrology 39, 689-710.

Patiño Douce, A. E. \& Johnston, A. D. (1991). Phase equilibria and melt productivity in the pelitic system: implications for the origin of peraluminous granitoids and aluminous granulites. Contributions to Mineralogy and Petrology 107, 202-218.

Partin, C. A., Bekker, A., Planavsky, N. J., Scott, C. T., Gill, B. C., Li, C., Podkovyrov, V., Maslov, A., Konhauser, K. O., Lalonde, S. V. \& Love, G. D. (2013). Large-scale fluctuations in Precambrian atmospheric and oceanic oxygen levels from the record of $U$ in shales. Earth and Planetary Science Letters 369, 284-293.

Payne, J. L., Hand, M., Pearson, N. J., Barovich, K. M. \& Mclnerney, D. J. (2015). Crustal thickening and clay: Controls on $\mathrm{O}$ isotope variation in global magmatism and siliciclastic sedimentary rocks. Earth and Planetary Science Letters 412, 70-76.

Peng, P., Guo, J.-H., Zhai, M.-G. \& Bleeker, W. (2010). Paleoproterozoic gabbronoritic and granitic magmatism in the northern margin of the North China Craton: evidence of crust-mantle interaction. Precambrian Research 183, 635-659. 
Peng, P., Guo, J. H., Windley, B. F., Liu, F., Chu, Z. \& Zhai, M. G. (2012). Petrogenesis of Late Paleoproterozoic Liangcheng charnockites and S-type granites in the central-northern margin of the North China Craton: implications for ridge subduction. Precambrian Research 222, 107-123.

Percival, J. A. (1986). Metamorphism and plutonism in the Quetico Belt, Superior Province, NW Ontario. In: Lunar and Planetary Institute Workshop of Early Crustal Genesis, The World's Oldest Rocks, pp. 84-85.

Percival, J. A. (1989). Granulite terranes and the lower crust of the Superior Province. In: Mereu, R. F., Mueller, S. \& Fountain, D. M. (eds) Properties and Processes of Earth's Lower Crust, Washington, DC: American Geophysical Union, pp. 301-310.

Percival, J. A. \& Easton, R. M. (2007). Geology of the Canadian Shield in Ontario: an update. Ontario Geological Survey, Open File Report 6196, $66 \mathrm{pp}$.

Percival, J. A., Sanborn-Barrie, M., Skulski, T., Stott, G. M., Helmstaedt, H. \& White, D. J. (2006). Tectonic evolution of the western Superior Province from NATMAP and Lithoprobe studies. Canadian Journal of Earth Sciences 43, 1085-1117.

Percival, J. A. \& Williams, H. R. (1989). Late Archean Quetico accretionary complex, Superior Province, Canada. Geology 17, 23-25.

Percival, J. A., Stern, R. A. \& Digel, M. R. (1985). Regional geological synthesis of western Superior Province, Ontario. Geological Survey of Canada Paper 85-1A, 385-397.

Peterman, Z. E., Hedge, C. E. \& Braddock, W. A. (1968). Age of Precambrian events in the northeastern Front Range, Colorado. Journal of Geophysical Research 73, 2277-2296.

Petersson, A., Scherstén, A., Kemp, A. I. S., Kristinsdottir, B., Kalvig, P. \& Anum, S. (2016). Zircon U-Pb-Hf evidence for subduction related crustal growth and reworking of Archaean crust within the Palaeoproterozoic Birimian terrane, West African Craton, SE Ghana. Precambrian Research 275, 286-309.

Pichavant, M., Montel, J. M. \& Richard, L. R. (1992). Apatite solubility in peraluminous liquids: Experimental data and an extension of the Harrison-Watson model. Geochimica et Cosmochimica Acta 56, 3855-3861.

Pickering, J. M. \& Johnston, D. A. (1998). Fluid-absent melting behavior of a two-mica metapelite: experimental constraints on the origin of Black Hills granite. Journal of Petrology 39, 1787-1804.

Planavsky, N. J. (2014). The elements of marine life. Nature Geoscience 7, 855.

Planavsky, N. J., Asael, D., Hofmann, A., Reinhard, C. T., Lalonde, S. V., Knudsen, A., Wang, X., Ossa Ossa, F., Pecoits, E., Smith, A. J. B., Beukes, N. J., Bekker, A., Johnson, T. M., Konhauser, K. O., Lyons, T. W. \& Rouxel, O. J. (2014). Evidence for oxygenic photosynthesis half a billion years before the Great Oxidation Event. Nature Geoscience 7, 283.

Pouclet, A., Vidal, M., Delor, C., Simeon, Y. \& Alric, G. (1996). Le volcanisme birimien du nord-est de la Cote-d'Ivoire, mise en evidence de deux phases volcano-tectoniques distinctes dans l'evolution geodynamique du Paleoproterozoique. Bulletin de la Société géologique de France 167, 529-541.

Poujol, M. (2001). U-Pb isotopic evidence for episodic granitoid emplacement in the Murchison greenstone belt, South Africa. Journal of African Earth Sciences 33, 155-163.

Poujol, M. \& Robb, L. J. (1999). New U-Pb zircon ages on gneisses and pegmatite from south of the Murchison greenstone belt, South Africa. South African Journal of Geology 102, 93-98.
Poujol, M., Robb, L. J., Anhaeusser, C. R. \& Gericke, B. (2003). A review of the geochronological constraints of the Kaapvaal Craton, South Africa. Precambrian Research 127, 181-213.

Qiao, H., Yin, C., Li, Q., He, X., Qian, J. \& Li, W. (2016). Application of the revised Ti-in-zircon thermometer and SIMS zircon $\mathrm{U}-\mathrm{Pb}$ dating of high-pressure pelitic granulites from the Qianlishan-Helanshan Complex of the Khondalite Belt, North China Craton. Precambrian Research 276, 1-13.

Qui, Y. \& Groves, D. I. (1999). Late Archean collision and delamination in the Southwest Yilgarn Block: the driving force for Archean orogenic lode gold mineralization. Economic Geology 94, 115-122.

Qui, Y. M. (1997). Long-lived granitoids magmatism in the Southern Cross province, Yilgarn craton, Western Australia, and its relationship with Archean gold mineralization. PhD thesis, University of Western Australia, Nedlands, WA, 298 pp.

Rämö, O. T., McLemore, V. T., Hamilton, M. A., Kosunen, P. J., Heizler, M. \& Haapala, I. (2003). Intermittent 1630-1220 Ma magmatism in central Mazatzal Province: New geochronologic piercing points and some tectonic implications. Geology 31, 335-338.

Rasmussen, B. \& Buick, R. (1999). Redox state of the Archean atmosphere: evidence from detrital heavy minerals in ca. 3250-2750 Ma sandstones from the Pilbara Craton, Australia. Geology 27, 115-118.

Redden, J. A., Norton, J. J. \& McLaughlin, R. J. (1982). Geology of the Harney Peak Granite, Black Hills, South Dakota. US Geological Survey, Professional Papers 82-481.

Redden, J. A., Peterman, Z. E., Zartman, R. E. \& DeWitt, E. (1990). U-Th-Pb geochronology and preliminary interpretation of Precambrian tectonic events in the Black Hills, South Dakota. Geological Association of Canada, Special Papers 37, 229-251.

Reed, J. C. \& Zartman, R. E. (1973). Geochronology of Precambrian rocks of the Teton Range, Wyoming. Geological Society of America Bulletin 84, 561-582.

Reinhard, C. T., Lalonde, S. V. \& Lyons, T. W. (2013). Oxidative sulfide dissolution on the early Earth. Chemical Geology $362,44-55$.

Reinhard, C. T., Planavsky, N. J., Gill, B. C., Ozaki, K., Robbins, L. J., Lyons, T. W., Fischer, W. W., Wang, C., Cole, D. B. \& Konhauser, K. O. (2017). Evolution of the global phosphorus cycle. Nature 541, 386-389.

Reis, N. J., de Faria, M. S. G., Fraga, L. M. B. \& Haddad, R. C. (2000). Orosirian calc-alkaline volcanism and the Orocaima event in the Northern Amazonian Cráton, Eastern Roraima State. Revista Brasileira de Geociências 30, 380-383.

Robb, L. J., Brandl, G., Anhaeusser, C. R. \& Poujol, M. (2006). Archaean granitoid intrusions. In Johnson, M. R., Anhaeusser, C. R. \& Thomas, R. J. (eds) The Geology of South Africa. Pretoria: Geological Society of South Africa: Johannesburg/Council of Geosciences, pp. 57-89.

Rockhold, J. R., Nabelek, P. I. \& Glascock, M. D. (1987). Origin of rhythmic layering in the Calamity Peak satellite pluton of the Harney Peak Granite, South Dakota: the role of boron. Geochimica et Cosmochimica Acta 51, 487-496.

Ronov, A. B. (1964). Common tendencies in the chemical evolution of the Earth's crust, ocean and atmosphere. Geochemistry International 1, 713-737.

Ross, G. M., Parrish, R. R., Villeneuve, M. E. \& Bowring, S. A. (1991). Geophysics and geochronology of the crystalline basement of the Alberta Basin, western Canada. Canadian Journal of Earth Sciences 28, 512-522.

Rouxel, O. J., Bekker, A. \& Edwards, K. J. (2005). Iron isotope constraints on the Archean and Paleoproterozoic ocean redox state. Science 307, 1088-1091. 
Sabaté, P., Marinho, M. M., Vidal, P. \& Caen-Vachette, M. (1990). The 2-Ga peraluminous magmatism of the Jacobina-Contendas Mirante belts (Bahia, Brazil): geologic and isotopic constraints on the sources. Chemical Geology 83, 325-338.

Santosh, M., Sajeev, K. \& Li, J. H. (2006). Extreme crustal metamorphism during Columbia supercontinent assembly: evidence from North China Craton. Gondwana Research 10, 256-266.

Sasaki, A. \& Ishihara, S. (1979). Sulfur isotopic composition of the magnetite-series and ilmenite-series granitoids in Japan. Contributions to Mineralogy and Petrology 68, 107-115.

Sawyer, E. W. \& Barnes, S. J. (1988). Temporal and compositional differences between subsolidus and anatectic migmatite leucosomes from the Quetico metasedimentary belt, Canada. Journal of Metamorphic Geology 6, 437-450.

Scaillet, B., Pichavant, M. \& Roux, J. (1991). Tourmaline, biotite and muscovite stability in felsic peraluminous liquids. EOS Transactions, American Geophysical Union 72, 311.

Schreurs, J. \& Westra, L. (1986). The thermotectonic evolution of a Proterozoic, low pressure, granulite dome, West Uusimaa, SW Finland. Contributions to Mineralogy and Petrology 93, 236-250.

Scott, C., Lyons, T. W., Bekker, A., Shen, Y., Poulton, S. W., Chu, X. \& Anbar, A. D. (2008). Tracing the stepwise oxygenation of the Proterozoic ocean. Nature 452, 456-458.

Sederholm, J. S. (1926). On migmatites and associated Precambrian rocks of SW Finland: ii: the region around Barosundsfjord. Bulletin de la Commission Géologique de Finlande 77, 143.

Sha, L. K. \& Chappell, B. W. (1999). Apatite chemical composition, determined by electron microprobe and laser-ablation inductively coupled plasma mass spectrometry, as a probe into granite petrogenesis. Geochimica et Cosmochimica Acta 63, 3861-3881.

Shand, S. J. (1927). Eruptive Rocks. New York: John Wiley.

Shearer, C. K., Papike, J. J. \& Laul, J. C. (1987). Mineralogical and chemical evolution of a rare-element granite-pegmatite system: Harney Peak Granite, Black Hills, South Dakota. Geochimica et Cosmochimica Acta 51, 473-486.

Shearer, C. K., Papike, J. J. \& Jolliff, B. L. (1992). Petrogenetic links among granites and pegmatites in the Harney Peak rare-element granite-pegmatite system, Black Hills, South Dakota. Canadian Mineralogist 30, 785-809.

Sheppard, S., Occhipinti, S. A. \& Nelson, D. R. (2005). Intracontinental reworking in the Capricorn Orogen, Western Australia: the 1680-1620 Ma Mangaroon Orogeny. Australian Journal of Earth Sciences 52, 443-460.

Shieh, Y. N. \& Schwarcz, H. P. (1978). The oxygen isotope composition of the surface crystalline rocks of the Canadian Shield. Canadian Journal of Earth Sciences 15, 1773-1782.

Silver, L. T., Williams, I. S. \& Woodhead, J. A. (1981). Uranium in granites from the southwestern United States: actinide parent-daughter system, sites, and mobilization. US Department of Energy, Open-File Report GJBX-45, 315 pp.

Smit, K. V., Shirey, S. B., Hauri, E. H. \& Stern, R. A. (2019). Sulfur isotopes in diamonds reveal differences in continent construction. Science 364, 383-385.

Smith, P. M. \& Asimow, P. D. (2005). Adiabat_1ph: a new public front-end to the MELTS, pMELTS, and pHMELTS models. Geochemistry, Geophysics, Geosystems 6, 002004.

Smithies, R. H. \& Champion, D. C. (2000). The Archaean high-Mg diorite suite: links to tonalite-trondhjemite-granodiorite magmatism and implications for early Archaean crustal growth. Journal of Petrology 41, 1653-1671.
Souders, A. K. \& Frost, C. D. (2006). In suspect terrane? Provenance of the late Archean Phantom Lake metamorphic suite, Sierra Madre, Wyoming. Canadian Journal of Earth Sciences 43, 1557-1577.

Southwick, D. L. (1991). On the genesis of Archean granite through two-stage melting of the Quetico accretionary prism at a transpressional plate boundary. Geological Society of America Bulletin 103, 1385-1394.

Southwick, D. L. \& Sims, P. K. (1979). The Vermilion Granitic Complex-A new name for old rocks in northern Minnesota. US Geological Survey, Professional Papers 1124A, A1-A11.

Spear, F. S., Kohn, M. J. \& Cheney, J. T. (1999). P-T paths from anatectic pelites. Contributions to Mineralogy and Petrology 134, 17-32.

Spencer, C. J., Cawood, P. A., Hawkesworth, C. J., Raub, T. D., Prave, A. R. \& Roberts, N. M. (2014). Proterozoic onset of crustal reworking and collisional tectonics: Reappraisal of the zircon oxygen isotope record. Geology 42, 451-454.

Spencer, C. J., Roberts, N. M. W. \& Santosh, M. (2017). Growth, destruction, and preservation of Earth's continental crust. Earth-Science Reviews 172, 87-106.

Spencer, C. J., Murphy, J. B., Kirkland, C. L., Liu, Y. \& Mitchell, R. N. (2018). A Palaeoproterozoic tectono-magmatic lull as a potential trigger for the supercontinent cycle. Nature Geoscience 11, 97-101.

SpencerC. J., Partin, C. A., Kirkland, C. L., Raub, T. D., Liebmann, J. \& Stern, R. A. (2019). Paleoproterozoic increase in zircon $\delta^{18} \mathrm{O}$ driven by rapid emergence of continental crust. Geochimica et Cosmochimica Acta 257, 16-25.

Stevens, G., Clemens, J. D. \& Droop, G. T. (1997). Melt production during granulite-facies anatexis: experimental data from 'primitive' metasedimentary protoliths. Contributions to Mineralogy and Petrology 128, 352-370.

Stevens, G., Villaros, A. \& Moyen, J. F. (2007). Selective peritectic garnet entrainment as the origin of geochemical diversity in S-type granites. Geology 35, 9-12.

St-Onge, M. R. \& Davis, W. J. (2018). Wopmay orogen revisited: Phase equilibria modeling, detrital zircon geochronology, and $\mathrm{U}-\mathrm{Pb}$ monazite dating of a regional Buchan-type metamorphic sequence. Geological Society of America Bulletin 130, 678-704.

Stott, G. M. (1996). The geology and tectonic history of the central Uchi Subprovince. Ontario Geological Survey, Open File Report 5952, $178 \mathrm{pp}$.

Stott, G. M., Corkery, J. A., Percival, M., Simard, M. \& Goutier, J. (2010). A revised terrane subdivision of the Superior Province of Ontario. Ontario Geological Survey, Open File Report 6260, 20-1-20-10.

Stuckless, J. S. (1989). Petrogenesis of Two Contrasting, Late Archean Granitoids, Wind River Range, Wyoming. US Geological Survey, Professional Papers 1491.

Stuckless, J. S. \& Miesch, A. T. (1981). Petrogenetic modeling of a potential uranium source rock, Granite Mountains, Wyoming. US Geological Survey, Professional Papers 1225.

Stuckless, J. S., Hedge, C. E., Worl, R. G., Simmons, K. R., Nkomo, I. T. \& Wenner, D. B. (1985). Isotopic studies of the late Archean plutonic rocks of the Wind River Range, Wyoming. Geological Society of America Bulletin 96, 850-860.

Suominen, V. (1991). The chronostratigraphy of southwestern Finland with special reference to Postjotnian and Subjotnian diabases. Geological Survey of Finland Bulletin 356, 100 pp.

Sverjensky, D. A. \& Lee, N. (2010). The great oxidation event and mineral diversification. Elements 6, 31-36.

Sweetapple, M. T. \& Collins, P. L. (2002). Genetic framework for the classification and distribution of Archean rare metal 
pegmatites in the North Pilbara Craton, Western Australia. Economic Geology 97, 873-895.

Sylvester, P. J. (1994). Archean granite plutons. In: Condie, K. C. (ed.) Archaean Crustal Evolution, Developments in Precambrian Geology, 11. Amsterdam: Elsevier, pp. 261-314.

Sylvester, P. J. (1998). Post-collisional strongly peraluminous granites. Lithos 45, 29-44.

Tang, M., Wang, X. L., Shu, X. J., Wang, D., Yang, T. \& Gopon, $P$. (2014). Hafnium isotopic heterogeneity in zircons from granitic rocks: Geochemical evaluation and modeling of 'zircon effect' in crustal anatexis. Earth and Planetary Science Letters 389, 188-199.

Taylor, J. \& Stevens, G. (2010). Selective entrainment of peritectic garnet into S-type granitic magmas: evidence from Archaean mid-crustal anatectites. Lithos 120, 277-292.

Taylor, P. N., Moorbath, S., Leube, A. \& Hirdes, W. (1992). Early Proterozoic crustal evolution in the Birimian of Ghana: constraints from geochronology and isotope geochemistry. Precambrian Research 56, 97-111.

Taylor, S. R. \& McLennan, S. M. (1995). The geochemical evolution of the continental crust. Reviews of Geophysics 33, 241-265.

Thériault, R. J. (1992). Nd isotopic evolution of the Taltson Magmatic Zone, Northwest Territories, Canada: insights into early Proterozoic accretion along the Western margin of the Churchill Province. Journal of Geology 100, 465-475.

Thomassot, E., Cartigny, P., Harris, J. W., Lorand, J. P., RollionBard, C. \& Chaussidon, M. (2009). Metasomatic diamond growth: A multi-isotope study $\left({ }^{13} \mathrm{C},{ }^{15} \mathrm{~N},{ }^{33} \mathrm{~S},{ }^{34} \mathrm{~S}\right)$ of sulphide inclusions and their host diamonds from Jwaneng (Botswana). Earth and Planetary Science Letters 282, 79-90.

Thurston, P. C. (1990). Early Precambrian basic rocks of the Canadian shield. In: Hall, R. P. \& Hughes E. J. (ed.) Early Precambrian Basic Magmatism. Glasgow: Blackie, pp. 221-247.

Tindle, A. G., Selway, J. B. \& Breaks, F. W. (2002). Electron microprobe and bulk analyses of fertile peraluminous granites and related rare-element pegmatites, Superior Province, northwest and northeast Ontario, Operation Treasure Hunt. Ontario Geological Survey, Miscellaneous Release Data, $111 \mathrm{pp}$.

Trumbull, R. B. (1993). A petrological and Rb-Sr isotopic study of an early Archean fertile granite-pegmatite system: the Sinceni pluton in Swaziland. Precambrian Research 61, 89-116.

Tweto, O. \& Schoenfeld, R. E. (1979). Geologic Map of Colorado. Reston, VA: US Geological Survey.

Vaasjoki, M. \& Sakko, M. (1988). The evolution of the Raahe-Ladoga zone in Finland: isotopic constraints. Geological Survey of Finland Bulletin 343, 7-32.

Väisänen, M. \& Hölttä, P. (1999). Structural and metamorphic evolution of the Turku migmatite complex, southwestern Finland. Geological Survey of Finland Bulletin 71, 177-218.

Väisänen, M., Manttari, I., Kriegsman, L. M. \& Hölttä, P. (2000). Tectonic setting of post-collisional magmatism in the Palaeoproterozoic Svecofennian Orogen, SW Finland. Lithos 54, 63-81.

Valley, J. W. (2003). Oxygen isotopes in zircon. In: Valley, J. W. (ed.) Oxygen Isotopes in Zircon. Mineralogical Society of America and Geochemical Society, Reviews in Mineralogy and Geochemistry 53, 343-385.

Valley, J. W., Lackey, J. S., Cavosie, A. J., Clechenko, C. C., Spicuzza, M. J., Basei, M. A. S., Bindeman, I. N., Ferreira, V. P., Sial, A. N., King, E. M., Peck, W. H., Sinha, A. K. \& Wei, C. S. (2005). 4.4 billion years of crustal maturation: oxygen isotope ratios of magmatic zircon. Contributions to Mineralogy and Petrology 150, 561-580.

van Breemen, O., Davis, W. J. \& King, J. E. (1992a). Temporal distribution of granitoid plutonic rocks in the Archean Slave Province, northwest Canadian Shield. Canadian Journal of Earth Sciences 29, 2186-2199.

van Breemen, O., Bostock, H. H. \& Loveridge, W. D. (1992b). Geochronology of granites along the margin of the northern Taltson magmatic zone and western Rae Province, Northwest Territories. Radiogenic age and isotopic studies: report 5, Geological Survey of Canada, Paper 91-2, 17-24.

Van Duin, J. A. \& Nieman, C. P. (1993). Pressure and temperature history of a low-pressure transitional granulite area, Turku, SW Finland. Geologie en Mijnbouw 71, 259-280.

Vearncombe, J. R. (1988). Structure and metamorphism of the Archean Murchison belt, Kaapvaal craton, South Africa. Tectonics 7, 761-774.

Vearncombe, J. R., Barton, J. M., Jr, Cheshire, P. E., De Beer, J. H., Stettler, E. H. \& Brandl, G. (1992). Geology, Geophysics and Mineralization of the Murchison Schist Belt, Rooiwater Complex and Surrounding Granitoids. Memoirs of the Geological Survey of South Africa, 139.

Veizer, J. \& Mackenzie, F. T. (2003). Evolution of sedimentary rocks. In: Mackenzie, F. T. (ed.) Treatise on Geochemistry 7, Pergamon, pp. 369-407.

Vidal, M. \& Alric, G. (1994). The Paleoproterozoic (Birimian) of Haute-Comoé in the West African Craton, Ivory Coast: a transtensional back-arc basin. Precambrian Research 65, 207-229.

Vielzeuf, D. \& Holloway, J. R. (1988). Experimental determination of the fluid-absent melting relations in the pelitic system. Contributions to Mineralogy and Petrology 98, 257-276.

Vielzeuf, D. \& Montel, J. M. (1994). Partial melting of metagreywackes. Part I. Fluid-absent experiments and phase relationships. Contributions to Mineralogy and Petrology 117, 375-393.

Villaros, A., Stevens, G. \& Buick, I. S. (2009). Tracking S-type granite from source to emplacement: clues from garnet in the Cape Granite Suite. Lithos 112, 217-235.

Walker, R. J., Hanson, G. N., Papike, J. J. \& O'Neil, J. R. (1986). $\mathrm{Nd}, \mathrm{O}$ and $\mathrm{Sr}$ isotopic constraints on the origin of Precambrian rocks, southern Black Hills, South Dakota. Geochimica et Cosmochimica Acta 50, 2833-2846.

Wall, E. N. (2004). Petrologic, geochemical, and isotopic constraints on the origin of $2.6 \mathrm{Ga}$ post-tectonic granitoids of the central Wyoming province. MSc thesis, University of Wyoming, Laramie, WY.

Wall, V. J., Clemens, J. D. \& Clarke, D. B. (1987). Models for granitoid evolution and source compositions. Journal of Geology 95, 731-750.

Wang, F., Li, X.-P., Chu, H. \& Zhao, G.-C. (2011). Petrology and metamorphism of khondalites from the Jining complex, North China craton. International Geology Review 53, 212-229.

Wang, L. J., Guo, J. H., Yin, C. \& Peng, P. (2017). Petrogenesis of ca. $1.95 \mathrm{Ga}$ meta-leucogranites from the Jining Complex in the Khondalite Belt, North China Craton: Water-fluxed melting of metasedimentary rocks. Precambrian Research 303, 355-371.

Wang, L. J., Guo, J. H., Yin, C., Peng, P., Zhang, J., Spencer, C. J. \& Qian, J. H. (2018). High-temperature S-type granitoids (charnockites) in the Jining complex, North China Craton: Restite entrainment and hybridization with mafic magma. Lithos 320, 435-453.

Watson, E. B. \& Capobianco, C. J. (1981). Phosphorus and the rare earth elements in felsic magmas: an assessment of the 
role of apatite. Geochimica et Cosmochimica Acta 45, 2349-2358.

Watson, E. B. \& Harrison, T. M. (1983). Zircon saturation revisited: temperature and composition effects in a variety of crustal magma types. Earth and Planetary Science Letters 64, 295-304.

Whalen, J. B. \& Chappell, B. W. (1988). Opaque mineralogy and mafic mineral chemistry of I- and S-type granites of the Lachlan fold belt, Southeast Australia. American Mineralogist 73, 281-296.

White, A. J. \& Chappell, B. W. (1977). Ultrametamorphism and granitoid genesis. Tectonophysics 43, 7-22.

Wilde, S. A., Zhao, G.-C. \& Sun, M. (2002). Development of the North China Craton during the Late Archean and its final amalgamation at $1.8 \mathrm{Ga}$ : some speculation on its position within a global Paleoproterozoic Supercontinent. Gondwana Research 5, 85-94.

Windley, B. F. (1977). Timing of continental growth and emergence. Nature 270, 426.

Wones, D. R. \& Eugster, H. P. (1965). Stability of biotite: experiment, theory, and application. American Mineralogist 50, 1228-1272.

Yin, C., Zhao, G., Guo, J., Sun, M., Xia, X., Zhou, X. \& Liu, C. (2011). U-Pb and $\mathrm{Hf}$ isotopic study of zircons of the Helanshan Complex: constrains on the evolution of the Khondalite Belt in the Western Block of the North China Craton. Lithos 122, 25-38.

Yin, C. Q., Zhao, G. C., Sun, M., Xia, X. P., Wei, C. J., Zhou, X. W. \& Leung, W. H. (2009). LA- ICP-MS U-Pb zircon ages of the Qianlishan Complex: constraints on the evolution of the Khondalite Belt in the Western Block of the North China Craton. Precambrian Research 174, 78-94.

Zartman, R. E. \& Reed, J. C., Jr (1998). Zircon geochronology of the Webb Canyon Gneiss and the Mount Owen Quartz Monzonite, Teton Range, Wyoming: significance to dating Late Archean metamorphism in the Wyoming craton. Mountain Geologist 35, 71-77.

Zeh, A., Gerdes, A. \& Barton, J. M. (2009). Archean accretion and crustal evolution of the Kalahari Craton-the zircon age and $\mathrm{Hf}$ isotope record of granitic rocks from Barberton/Swaziland to the Francistown Arc. Journal of Petrology 50, 933-966.

Zen, E. A. (1988). Phase relations of peraluminous granitic rocks and their petrogenetic implications. Annual Review of Earth and Planetary Sciences 16, 21-51.
Zeng, L., Asimow, P. D. \& Saleeby, J. B. (2005a). Coupling of anatectic reactions and dissolution of accessory phases and the $\mathrm{Sr}$ and $\mathrm{Nd}$ isotope systematics of anatectic melts from a metasedimentary source. Geochimica et Cosmochimica Acta 69, 3671-3682.

Zeng, L., Saleeby, J. B. \& Asimow, P. (2005b). Nd isotope disequilibrium during crustal anatexis: $A$ record from the Goat Ranch migmatite complex, southern Sierra Nevada batholith, California. Geology 33, 53-56.

Zhai, M., Guo, J., Li, Y., Liu, W., Peng, P. \& Shi, X. (2003). Two linear granite belts in the central-western North China Craton and their implication for Late Neoarchaean-Palaeoproterozoic continental evolution. Precambrian Research 127, 267-283.

Zhang, D. H., Wei, J. H., Fu, L. B., Schmitt, A. K., Wang, D. Z., Tan, J. \& Liu, J. K. (2017). Petrogenesis and thermal overprint of S-type granites in Helanshan region, North China Craton: Constraints on the $1.90 \mathrm{Ga}$ khondalites decompression melting and $1.32 \mathrm{Ga}$ tectono-thermal event. Precambrian Research 303, 660-672.

Zhang, X., Zhang, Y., Zhai, M., Wu, F., Hou, Q. \& Yuan, L. (2017). Decoding Neoarchaean to Palaeoproterozoic tectonothermal events in the Rangnim Massif, North Korea: regional correlation and broader implications. International Geology Review 59, 16-28.

Zhao, G. \& Zhai, M. (2013). Lithotectonic elements of Precambrian basement in the North China Craton: review and tectonic implications. Gondwana Research 23, 1207-1240.

Zhao, G., Wilde, S. A., Cawood, P. A. \& Sun, M. (2001). Archean blocks and their boundaries in the North China Craton: lithological, geochemical, structural and $P-T$ path constraints and tectonic evolution. Precambrian Research 107, 45-73.

Zhao, G., Sun, M., Wilde, S. A. \& Sanzhong, L. (2005). Late Archaean to Palaeoproterozoic evolution of the North China Craton: key issues revisited. Precambrian Research 136, 177-202.

Zhao, G., Cao, L., Wilde, S. A., Sun, M., Choe, W. J. \& Li, S. (2006). Implications based on the first SHRIMP U-Pb zircon dating on Precambrian granitoid rocks in North Korea. Earth and Planetary Science Letters 251, 365-379.

Zhong, C.-T., Deng, J.-F., Wan, Y.-S., Mao, D.-B. \& Li, H.-M. (2007). Magma recording of Paleoproterozoic orogeny in central segment of northern margin of North China craton: geochemical characteristics and zircon SHRIMP dating of S-type granitoids. Geochimica 36, 633-637 [in Chinese with English abstract]. 
